\title{
SUGGESTED CRITERIA FOR HYDROLOGIC DESIGN OF \\ STORM-DRAINAGE FACILITIES \\ IN THE SAN FRANCISCO BAY REGION CALIFORNIA
}

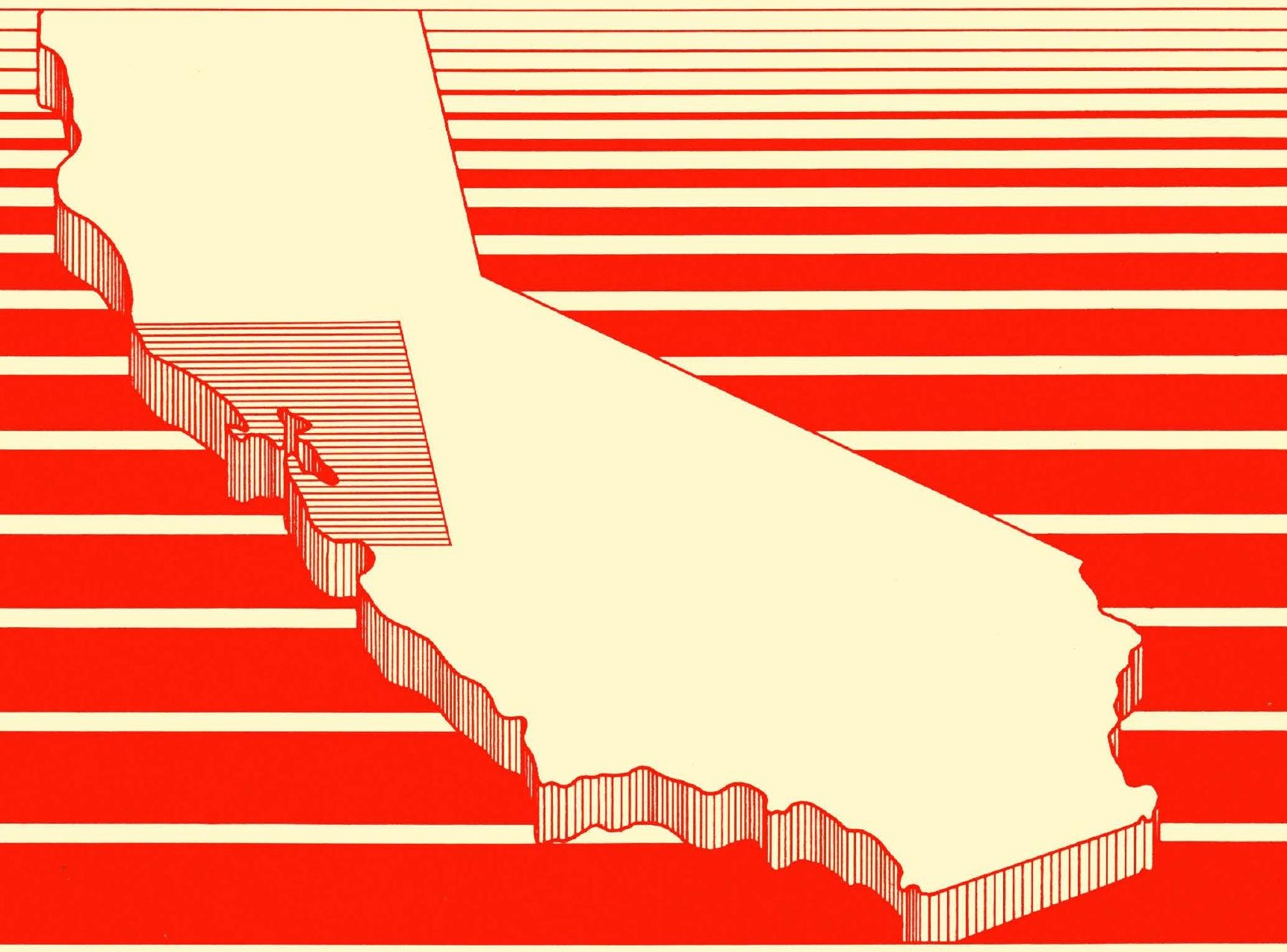

UNITED STATES DEPARTMENT OF THE INTERIOR GEOLOGICAL SURVEY WATER RESOURCES DIVISION Menlo Park, California, 1971 OPEN-FILE REPORT

PREPARED IN COOPERATION WITH

THE U.S. DEPARTMENT OF HOUSING AND URBAN DEVEOPMENT 
UNITED STATES

DEPARTMENT OF THE INTERIOR

GEOLOGICAL SURVEY

Water Resources Division

\section{SUGGESTED CRITERIA FOR HYDROLOGIC DESIGN OF \\ STORM-DRAINAGE FACILITIES IN THE \\ SAN FRANCISCO BAY REGION, CALIFORNIA}

By

S. E. Rantz

Prepared in cooperation with the

U.S. Department of Housing and Urban Development

OPEN-FILE REPORT

Menlo Park, California

November 24, 1971 


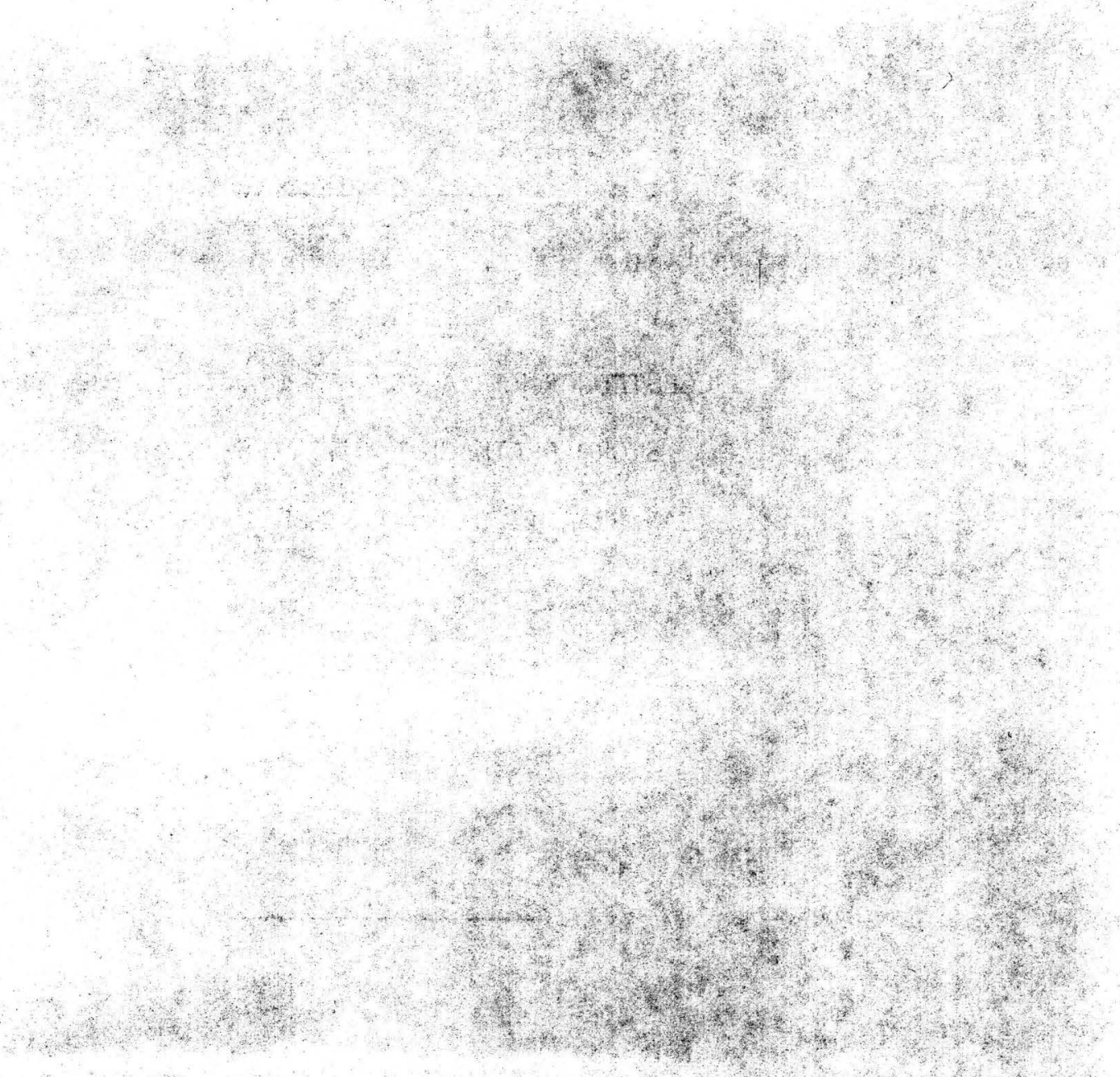

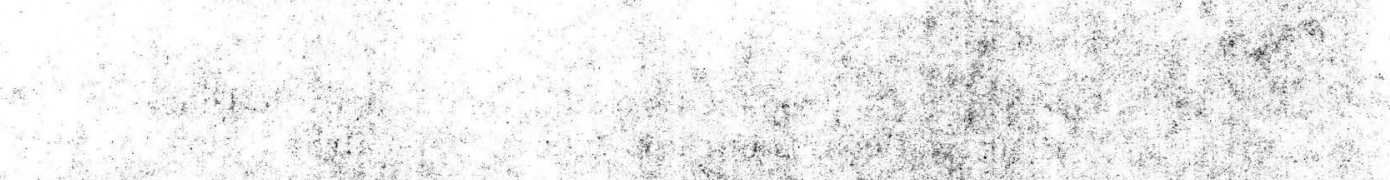




\section{CONTENTS}

Abstract--

Page

Introduction-...

Purpose and scope-1

Data deficiencies-...

Relation of impervious area to type of development-... Natural condition--..Urbanized condition-_... Characteristics of urban development that affect storm runoff---

Flood-frequency analysis-..Natural conditions-... Urbanized conditions-1.

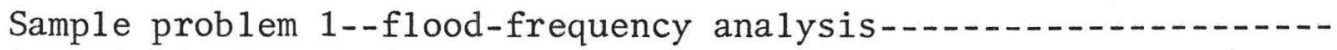
Appraisal of method-_.

Rationa1 Method-_. Determination of coefficient, CDetermination of precipitation intensity-... Sample problem 2--Rational Method-_Appraisal of method-..-

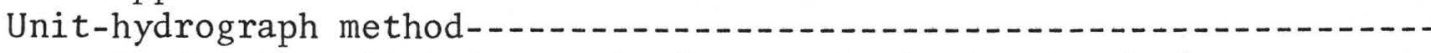

Synthetic unit hydrographs for unurbanized watersheds.........

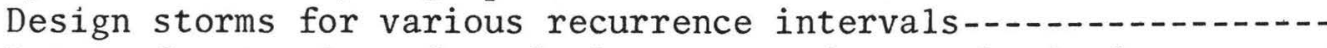
Rates of water loss from design storms for unurbanized watersheds-.....

Base flow for design floods-..... Results of unit-hydrograph computations for unurbanized watersheds-.....

Sample problem 3--unit-hydrograph method (unurbanized watersheds) Synthetic unit hydrographs for urbanized watersheds-........-. Design storms and rates of water loss for urbanized watersheds-..- 46

Sample problem 4--unit-hydrograph method (urbanized watersheds) - 47

Appraisal of method-_. 55

Runoff simulation using hydrologic basin models

Transposition of storm-precipitation data-... 56

Application of storm-increment ratios-1-.-1 65

Appraisal of method-_.... 66

Suggested practices to reduce peak discharges in urban areas.......- 67

References cited-_... 69 


\section{ILLUSTRATIONS}

Figure 1. Map showing location of report area-1

Page

2. Map showing stream-gaging stations used in flood-

frequency analysis and in derivation of regional

unit hydrograph-..... 12

3. Ratios of flood-peak magnitude for urbanized basins to that for unurbanized basins--for use with flood-

frequency method- Flood-frequency relation for unurbanized hypothetical
4. watershed of sample problem 1- 17

5. Relation of $C$ to percentage of impervious area--for use in Rationa1 Method-... 20

6. Relation of overland time of travel to overland travel distance, average overland slope, and coefficient C-for use in Rational Method-...

7. Basic triangular unit hydrograph-

8. Instantaneous unit-hydrograph relations for unurbanized watersheds: (a) Lag versus $A / S^{\frac{1}{2}}$; (b) $T_{B}$ versus $A / S^{\frac{1}{2}}$

9. Comparison of design discharges for unurbanized watersheds computed by flood-frequency and unit

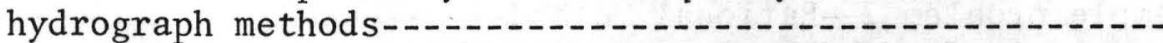

10-12. Comparison of ratios of flood-peak magnitude for urbanized basins to that for unurbanized basins, obtained by flood-frequency and unit-hydrograph methods, for:

10. 2- and 5-year recurrence intervals-_..-

11. 10- and 25-year recurrence intervals-_.-.-.

12. 50- and 100-year recurrence intervals-_..--

13-18. Curves showing relation between mean annual precipitation ratios and:

13. 1-hour precipitation ratios-

14. 2-hour precipitation ratios--

15. 3-hour precipitation ratios--

16. 6-hour precipitation ratios--

17. 12-hour precipitation ratios--

18. 24-hour precipitation ratios-

TABLES

Table 1. Regional design values of percentage of impervious area and of $C$ in the Rational Method-- 
Table 3. Results of flood-frequency analysis--multiple-regression equations and associated statistics for peak discharges

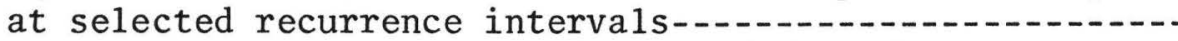

4. Precipitation depth-duration-frequency data for the San Francisco Bay region-...

5. Basin characteristics and IUH properties of watersheds used in the unit-hydrograph study--..-

6. Equations for computing dimensions of triangular unit hydrographs for use with unurbanized watersheds in the San Francisco Bay region-...

7. Cumulative time distributions of precipitation for various storm durations--...

8. Design $\Phi$-values for selected values of mean annual precipitation and recurrence interval, for use with unurbanized watersheds-....

9. Base flow for design floods-...

10. Comparison of results of peak discharge determinations for unurbanized watersheds, by flood-frequency analysis and by unit-hydrograph method-.......-.

11. Computation of design discharge hydrograph--sample problem 3--...

12. Computation of design precipitation excess--sample problem 3-...

13. Coefficients to convert time dimensions--lag, $T_{B_{I}}$, and $T_{P_{I}}{ }^{- \text {-of }}$ the IUH for an unurbanized watershed to those of the IUH for an urbanized or partly urbanized

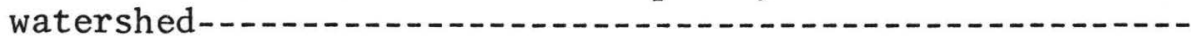

14. Coefficients to convert $\Phi$-values for an unurbanized watershed to those for an urbanized or partly

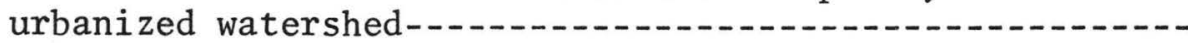

15. Ordinates of 5-minute triangular unit hydrograph-sample problem 4-...

16. Computation of storm precipitation in increments of 5 -minutes--sample problem 4--

17. Ordinates of design hydrograph of surface runoff--sample problem 4-.....

18. Derivation of curve for mean annual precipitation of 40 inches in figure 13. 

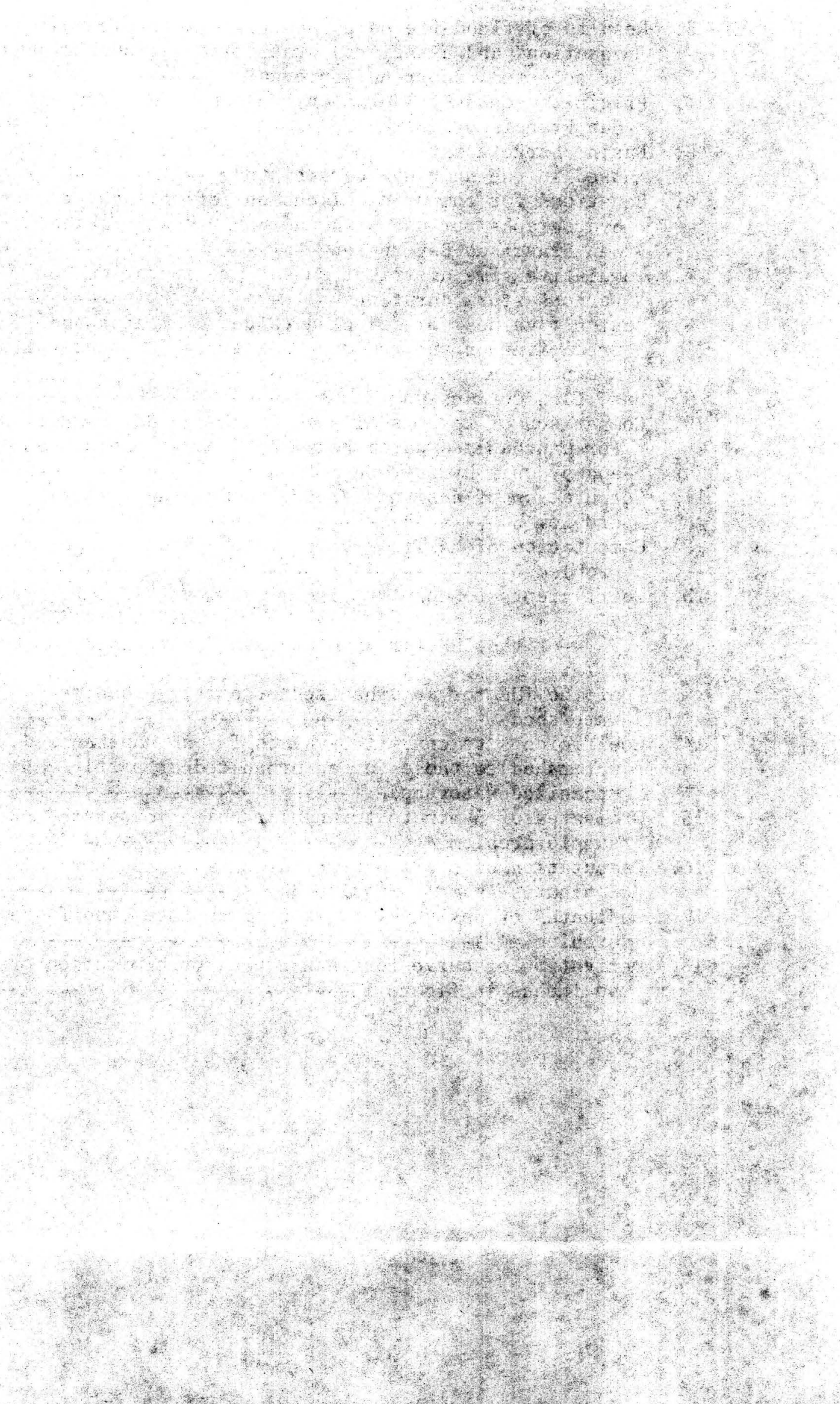
SUGGESTED CRITERIA FOR HYDROLOGIC DESIGN OF STORM-DRAINAGE FACILITIES

IN THE SAN FRANCISCO BAY REGION, CALIFORNIA

By S. E. Rantz

ABSTRACT

This report presents basic criteria, in the form of tables and graphs, for each of the four methods of hydrologic design most commonly used in the San Francisco Bay region--flood-frequency analysis, Rational Method, unit-hydrograph method, and runoff simulation by means of hydrologic basin modeling. The term "hydrologic design" as used in this report refers to the computation of either design values of peak discharge or design hydrographs of storm runoff. The hydraulics of open-channel and pipeline flow and the actual design of appurtenances for conveying the runoff are not discussed in this paper.

Use of the suggested criteria results in fairly close agreement between peak discharges computed by the flood-frequency and unit-hydrograph methods. Those peak discharges are not directly comparable with discharges computed by the Rational Method, in part because the results obtained by the Rational Method are affected by the values assigned to parameters for overland and channel flow. Those parameters are additional to the ones used in the flood-frequency and unit-hydrograph methods. A demonstration of runoff simulation by use of a hydrologic basin model is beyond the scope of this paper--such demonstrations are found in the appropriate references cited. However, this report does present an original technique for transposing storm rainfall in the region, storm transposition being commonly required to obtain the precipitation input used with hydrologic basin mode1s. 


\section{INTRODUCTION}

\section{Purpose and Scope}

In the design of storm-drainage facilities it is necessary to consider the probability of occurrence of runoff events in order to achieve an economic balance between the cost of structures and the direct and indirect costs of possible property damage and inconvenience to the public during the life of the structures. Therefore, as a preliminary to the design of drainage structures, the engineer computes storm discharges corresponding to various probabilities. Such computation will hereafter be referred to as "hydrologic design." The methodologies currently used in hydrologic design vary widely in the San Francisco Bay region (fig. 1), reflecting differences in the funding available for such design and differences in either the hydrologic ideology or hydrologic sophistication of the drainage engineers involved. The use of probability concepts to obtain economical design is universal, but beyond that, practices diverge widely. Furthermore, even within any single method of hydrologic design, the criteria basic to that method vary among users.

The purpose of this report is to suggest basic criteria for each of the more commonly used design methods, thereby promoting regional consistency and possible improvement in the methods. The criteria discussed are those used for computing either design values of peak stormdischarge or design hydrographs of storm runoff. Not discussed in this paper are the hydraulics of open-channel and pipeline flow and the actual design of appurtenances for conveying the runoff. Those two subjects are adequately covered in the references cited at the end of this report and in organizational handbooks available to drainage engineers. Design criteria are given for watersheds in their natural conditions and under varying conditions of urbanization; that is, variation in the percentage of impervious area and percentage of channels paved or lined. The designer can thus select his criteria, in advance of development, on the basis of the type of development planned.

This report has five major subdivisions. The first establishes percentages of impervious area to be used in hydrologic design for various types of urban development, such as industrial, commercial, light residential, apartments, and public buildings. The remaining four subdivisions establish criteria for each of the four most commonly used methods of hydrologic design--flood-frequency analysis, Rational Method, unit-hydrograph method, and runoff simulation by means of hydrologic basin modeling. 


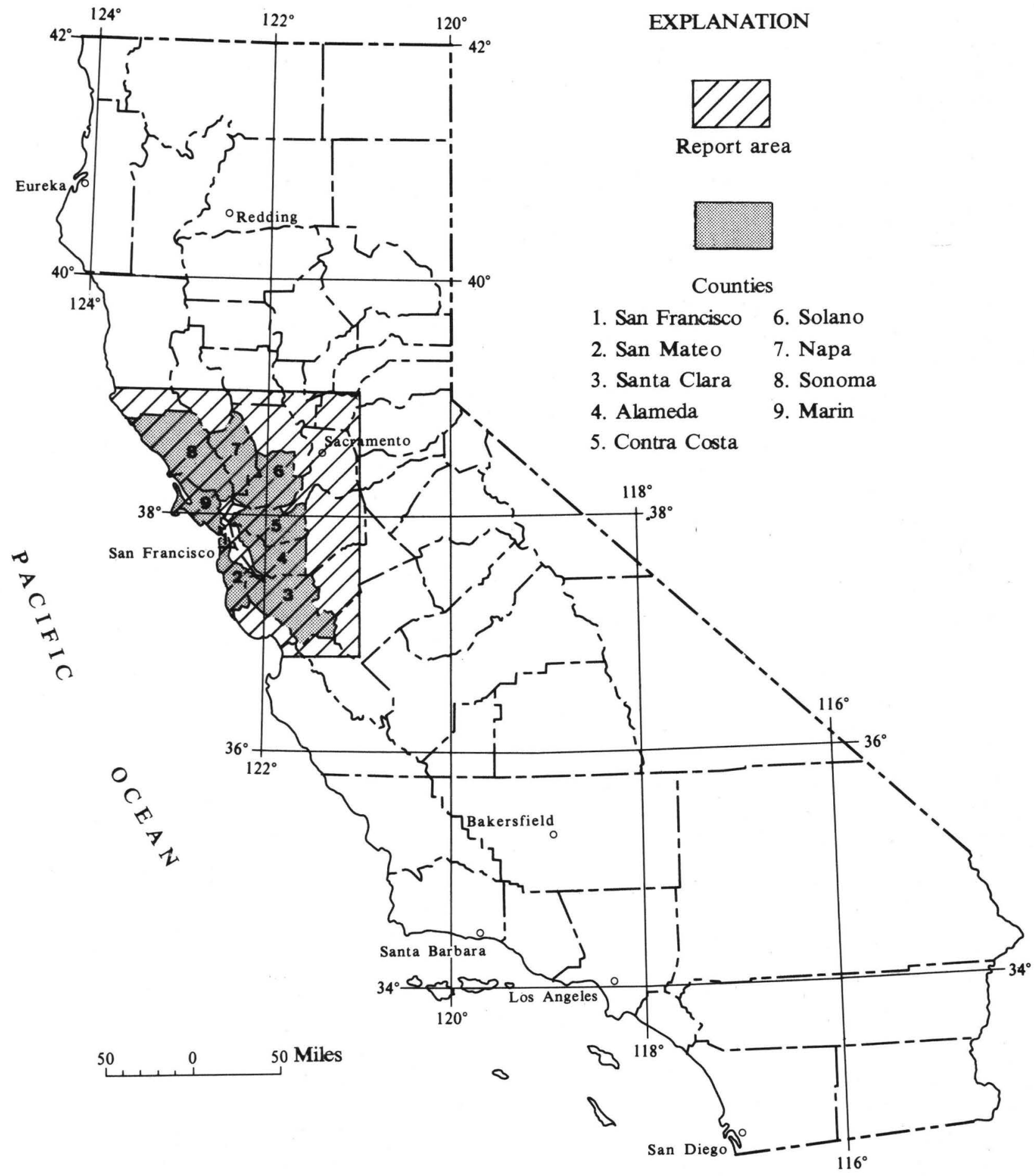

FIGURE 1.--Location of report area. 
Discharges obtained by the various methods described and illustrated in this paper are satisfactory from a statistical standpoint, in that they satisfactorily duplicate observed discharges for most of the watersheds used in the study. However, because the methods are essentially generalized functions for describing the regimen of precipitation and runoff in the San Francisco Bay region, anomalies in the form of large differences between computed and observed discharge do exist for some watersheds. Consequently, where precipitation and (or) discharge data are available at or near a study site, computed storm precipitation and (or) discharge should be compared with the available data for a general evaluation of the reasonableness of the computed figures. However, no modification of the computations should be considered that is not based on facts.

It is not the intent of this report to "convert" the drainage engineer to any particular method of hydrologic design, but the advantages and disadvantages of each are discussed. Furthermore, because the report is directed to the drainage engineer, who has a familiarity with the subject, none of the hydrologic methods are described in detail. The report is intended to supplement, not to replace, the descriptive handbooks and other reference material customarily used by the engineer.

For the reader who is interested solely in the application of the techniques described in this paper, and who is not concerned with the background or derivation of the relations and equations presented, a summary report will be prepared under separate cover, titled "Hydrologic Design of Storm-Drainage Facilities in the San Francisco Bay Region, California--Summary Report of Suggested Criteria," by S. E. Rantz.

The present report was prepared by the U.S. Geological Survey, Water Resources Division, in cooperation with the U.S. Department of Housing and Urban Development. The work was done during 1971 under the overall direction of R. E. Wallace, project director of the San Francisco Bay region environment and resources planning study, and under the general supervision of R. Stanley Lord, district chief in charge of water-resources investigations in California.

\section{Data Deficiencies}

This study was handicapped by a lack of pertinent data for small watersheds. Only in the last 15 years has the Geological Survey made a concerted effort to obtain runoff data for California watersheds smaller than 10 square miles, and consequently few small streams in the San Francisco Bay region have as much as 10 years of runoff record. Furthermore, data are almost completely lacking for determining the effect of urban development on storm runoff, and it was therefore necessary to rely on the results obtained in similar investigations elsewhere in the Nation. Those results, as represented by coefficients to adjust natural flow for the effect of various degrees of urban development, have been modified somewhat to make them more compatible with development practices currently followed in the region. 
RELATION OF IMPERVIOUS AREA TO TYPE OF DEVELOPMENT

Development of a watershed for habitation and attendant commercial and (or) industrial activity--hereafter loosely referred to as "urbanization" in this report--is a factor to be considered in the hydrologic design of storm drainage. The following brief discussion, differentiating between natural and urbanized conditions as they relate to storm runoff, is relevant to later discussion of suggested criteria for the various methods of hydrologic design.

\section{Natura1 Condition}

The term "natural condition" refers primarily to a condition such that only a negligible percentage of watershed area has been made impervious by development. In such areas channel improvement, if any, is confined to main channels only. While the main-channel improvement may affect the timing of runoff, and therefore the magnitude of the peak discharge, its greatest effect is usually on the stage-discharge relation; that is, the change in peak discharge is usually sma11, but the stage corresponding to that peak discharge is often reduced significantly by the channel improvement.

\section{Urbanized Condition}

The term "urbanized condition" refers to a condition whereby a significant percentage of the watershed has been made impervious by development. New urban developments are usually sewered for storm drainage as construction proceeds, but that is not always the case. The term "percentage of channels sewered," used later, refers then to the percentage of we11-defined channels that are lined or paved or replaced by pipe.

Peak discharges are usually increased when a basin becomes urbanized. Not only does the infiltration of rainfall decrease, but lag time or the time response of runoff to precipitation is usually decreased, as increasingly large percentages of the basin are made impervious and as drainage channels are lined, paved, or replaced by pipe. The net result is usually a greater concentration of storm runoff in a channel and greater peak flows. The degree to which peak flows are increased a1so depends on the manner in which the runoff from impervious surfaces reaches the collector channels. 
The percentage of impervious area in a watershed is easily measured, but only rarely does the entire impervious area have a direct or surface connection with a "principal" watercourse. Because there are many ways in which rain, falling on an impervious area, may be disposed of, it is not a simple matter to assign a percentage of impervious area that is meaningful in a hydrologic sense, to an urbanized or partly urbanized watershed. For example, in the Palo Alto-Menlo Park area which straddles the Santa Clara-San Mateo County Line, rainfall reaching a roof may leave in one or more of the following ways:

1. Through a downspout into a dry we11, and thence to the underlying ground-water body (USGS [U.S. Geological Survey] Center, Menlo Park) .

2. Surface storage and eventual evaporation (horizontal roofs of Eichler tract homes, Palo Alto).

3. Through a downspout to a "spatter-block" and thence over a lawn, all or a part of which may infiltrate the lawn (Eichler tract homes, Palo Alto).

4. Through a downspout and pipe drain into the street gutter (Sharon Heights suburb of Menlo Park).

It can be seen that surface runoff, resulting from precipitation on impervious roofs in individual parts of the Palo Alto-Menlo Park area, ranges from zero to almost 100 percent of the rainfall.

For purposes of hydrologic design in the San Francisco Bay region, a set of percentage values of impervious area for various types of development is presented in column 4 of table 1 . The values are hydrologically representative, in a general way, of current development practices in the region, and are based on those used by Santa Clara County (1965) in its master drainage plan (columns 2 and 3 of table 1). The Santa Clara County values in column 3 are consistently lower than those used elsewhere. They have been subjectively adjusted upward in column 4 by percentages that are small relative to design factors used in most other parts of the Nation, to fit the author's concept of optimum design values for the region. Columns 5 and 6 of table 1 are discussed in a later section of this report.

It was mentioned earlier that coefficients to adjust natural storm runoff for the effect of various degrees of urban development were obtained from studies made elsewhere in the United States, and that those coefficients were then modified to make them more compatible with development practices currently followed in the region. The basis for that modification of coefficients was provided by the tabulation of percentages of impervious area in column 4 of table 1 . The coefficients themselves are of the "lumped" type--they reflect average overal1 characteristics of urban development in a region, and not the detailed characteristics of any particular urban development in that region. A discussion of those characteristics that have a major effect on storm runoff follows. 
TABLE 1.--Regional design values of percentage of impervious area and of $\mathrm{C}$ in the Rational Method

\begin{tabular}{|c|c|c|c|c|c|}
\hline \multirow[b]{2}{*}{$\begin{array}{c}\text { Type of development } \\
\text { (1) }\end{array}$} & \multirow{2}{*}{$\begin{array}{c}\text { Density, } \\
\text { in units } \\
\text { per acre } \\
(2)\end{array}$} & \multicolumn{2}{|c|}{ Percent impervious } & \multicolumn{2}{|c|}{$C$, in Rational Method } \\
\hline & & \begin{tabular}{|c|} 
Santa Clara \\
County \\
$(3)$
\end{tabular} & \begin{tabular}{|c|c|}
$\begin{array}{c}\text { San Francisco } \\
\text { Bay Region } \\
(4)\end{array}$ \\
\end{tabular} & $\begin{array}{r}\text { ASCE } \\
(5) \\
\end{array}$ & $\begin{array}{c}\begin{array}{c}\text { San Francisco } \\
\text { Bay Region } \\
(6)\end{array} \\
\end{array}$ \\
\hline \multicolumn{6}{|l|}{ Residential: } \\
\hline $\begin{array}{l}\text { Hill areas } \\
\text { Low urbanization }\end{array}$ & $0.5-2$ & 6 & 8 & -- & $0.11-0.30$ \\
\hline $\begin{array}{l}\text { Low urbanization } \\
\text { Medium urbanization }\end{array}$ & $3-6$ & 10 & 15 & $0.25-0.40$ & $.21-.38$ \\
\hline $\begin{array}{l}\text { Medium urbanization } \\
\text { Heavy urbanization }\end{array}$ & $\begin{array}{ll}7 & -10\end{array}$ & 20 & 25 & $.30-.50$ & $.32-.52$ \\
\hline $\begin{array}{l}\text { Heavy urbanization } \\
\text { (apartments) }\end{array}$ & $11-20$ & 32 & 40 & $.50-.70$ & $.45-.70$ \\
\hline \multicolumn{6}{|l|}{ Industrial: } \\
\hline $\begin{array}{l}\text { Nonmanufacturing } \\
\text { Manufacturing }\end{array}$ & & 50 & 60 & $.60-.90$ & $.58-.88$ \\
\hline $\begin{array}{l}\text { Manufacturing } \\
\text { Reserve }\end{array}$ & & 40 & 50 & $.50-.80$ & $\begin{array}{r}.52-.79 \\
32-.52\end{array}$ \\
\hline Commercial & & 20 & 20 & & $.02-02$ \\
\hline & & 50 & 60 & $.50-.95$ & $.58-.88$ \\
\hline Transporation & & 70 & 75 & $.70-.95$ & $.60-.90$ \\
\hline Public buildings & & 40 & 50 & -- & $.52-.79$ \\
\hline Public parks & & 12 & 12 & $.10-.25$ & $.16-.32$ \\
\hline Agricultural & & 4 & 4 & -- & $.10-.30$ \\
\hline Natural watersheds & & 2 & 2 & -- & $.10-.30$ \\
\hline
\end{tabular}

\section{Characteristics of Urban Development that Affect Storm Runoff}

Location of impervious areas.--The specific location of an urban development within a watershed affects the runoff at the mouth of the watershed. For example, let us assume that one-third of the area of a natural watershed has been urbanized. If the 33 percent of developed area is near the mouth of the basin, the reduction in time response of runoff to rainfall in the urbanized lower basin may result in its heavy runoff leaving the basin before the peak flows from the headwater areas arrive at the mouth. The net result--possibly smaller peak flows in the downstream reaches of the main channel as a result of the urbanization. Conversely, if the 33 percent of development is in headwater areas, the reduction of time response of runoff to rainfall in the urbanized headwaters will result in an increased discharge in the lower reaches of the main channel. If the 33 percent of development is scattered throughout the basin, the result can be anything, depending on the configuration of the development with respect to drainage channels. 
The above statement concerning development in the lower part of the basin is a generality, and physical and climatic conditions may be decisive factors. As an example, we refer again to the Palo AltoMenlo Park area. The subhumid flatlands south of Palo Alto are now almost completely urbanized. Prior to urbanization those areas were occupied by orchards. The hilly and more humid headwater areas of the small streams that drain the flatlands are still largely in their natural forested state. The orchards were furrowed to reduce runoff and thereby conserve as much as possible of the 15 inches of mean annual rainfall. Consequently, before urbanization the flatlands contributed insignificantly to main channel streamflow. Since urbanization, their contribution is significant.

Hydraulic characteristics of impervious areas.--We have already seen how greatly building practices can affect the runoff rate of roof drainage (p. 6). The design of the sewer system itself--the location and number of storm-sewer connections--also has a significant effect on flow rates. Peak flows in a main, for example, are affected by the timing of peak flows in the tributary laterals. There is wide variation, however, in the design of sewer systems within a region, and this is attested to in a study made by the University of Wisconsin (Ardis and others, 1969).

Furthermore, modern drainage design often incorporates storage into the storm-sewer system. Greenways and other detention basins that serve a secondary recreation function are sometimes built into the system. Street drain-inlets are commonly designed for relatively small peak discharges (3- to 5-year recurrence interval), thereby assuring storage of runoff in the streets when storms of unusually large magnitude occur. The effect of this built-in storage is to reduce the magnitude of flood peaks associated with infrequent major storms, and thereby counteract, to at least a degree, the strong tendency of peak discharge to increase with urbanization.

Adjustment of natural peak discharges for effect of urbanization.-The most feasible method of treating the individual characteristics of urban development in an analysis of storm discharge is by runoff simulation using a distributive hydrologic basin model. Such models are discussed briefly later in this paper. The other three methods of storm-runoff analysis discussed in this report--flood-frequency analysis, Rational Method, and unit-hydrograph method--do not have that capability of treating individual urban characteristics. Those three methods require the use of lumped regional coefficients that grossly adjust natural discharge for the combined effect of all pertinent urbanization characteristics. 
Because the location of the development in a partly urbanized basin is a critical factor (p. 7-8), it is normally considered inadvisable to use lumped coefficients in adjusting natural runoff for the effect of partial urbanization. Partly urbanized basins are commonplace in the San Francisco Bay region--the hilly upper part of such basins remain in their natural state, while the flatter lands downstream are developed. Ideally, the discharges from the urbanized and unurbanized subareas should be computed independently and combined by a routing procedure. However, two of the methods discussed--flood-frequency analysis and Rational Method--do not provide the complete discharge hydrographs required for routing. Furthermore, as mentioned earlier, there are virtually no data for the region on which to base coefficients for adjusting natural discharge for the effect of urbanization, either partial or complete. The coefficients that will be suggested in this report have been borrowed from the work of investigators elsewhere in the Nation. In view of the uncertainty concerning the coefficients and in the interest of expediency, coefficients will be given for use with partly, as well as completely, developed basins. The use of these coefficients is recommended only until such time when data become available for a more scientific study of the effect of urbanization on streamflow.

FLOOD-FREQUENCY ANALYSIS

Natura1 Conditions

Regional flood-frequency relations were prepared on the basis of records for 40 gaging stations within or just outside the study area. The stations, listed in table 2 and shown with identifying number in figure 2, are those with 10 or more years of record of momentary peak discharge not seriously affected by regulation or diversion. None of the 40 watersheds are urbanized to any significant degree. Some fairly large watersheds were included in the analysis because of the dearth of small gaged watersheds with long-term records, and also to ensure a smooth floodfrequency relation in the transition from small to large streams. 
TABLE 2.--Data used in derivation of flood-frequency relations

\begin{tabular}{|c|c|c|c|c|c|c|c|c|c|}
\hline \multicolumn{2}{|c|}{ Gaging station } & \multirow{2}{*}{$\begin{array}{l}\text { Drainage } \\
\text { area } \\
(\mathrm{sq} \mathrm{mi})\end{array}$} & \multirow{2}{*}{\begin{tabular}{|c}
\multicolumn{1}{c}{ Mean } \\
annual \\
precip- \\
itation \\
(inches)
\end{tabular}} & \multirow{2}{*}{$\mid \begin{array}{c}\text { Main } \\
\text { channe1 } \\
\text { slope } \\
\text { (feet } \\
\text { per mile) }\end{array}$} & \multicolumn{5}{|c|}{$\begin{array}{c}\text { Discharge, in efs, for recurrence intervals } \\
\text { indicated below }\end{array}$} \\
\hline $\begin{array}{c}\text { Number } \\
\text { (fig. 2) }\end{array}$ & Name & & & & $\begin{array}{c}2 \text { years } \\
\left(Q_{2}\right)\end{array}$ & $\begin{array}{c}5 \text { years } \\
\left(Q_{5}\right)\end{array}$ & $\begin{array}{c}10 \text { years } \\
\left(Q_{10}\right)\end{array}$ & $\begin{array}{c}25 \text { years } \\
\left(Q_{25}\right)\end{array}$ & $\begin{array}{c}50 \text { years } \\
\left(Q_{50)}\right.\end{array}$ \\
\hline 1591.5 & $\begin{array}{l}\text { Corralitos Creek } \\
\text { near Corralitos }\end{array}$ & 10.6 & 35 & 284.0 & 727 & 1,580 & 2,060 & 2,500 & 2,730 \\
\hline 1592 & $\begin{array}{l}\text { Corralitos Creek } \\
\text { at Freedom }\end{array}$ & 27.8 & 35 & 80.3 & 1,250 & 2,550 & 3,220 & 3,800 & 4,080 \\
\hline 1600 & $\begin{array}{l}\text { Soque1 Creek } \\
\text { at Soquel }\end{array}$ & 40.2 & 40 & 121 & 3,090 & 6,730 & 9,070 & 11,600 & 13,200 \\
\hline 1603 & $\begin{array}{l}\text { Zayante Creek } \\
\text { at Zayante }\end{array}$ & 11.1 & 50 & 200 & 988 & 2,650 & 3,860 & 5,240 & 6,100 \\
\hline 1605 & $\begin{array}{l}\text { San Lorenzo River } \\
\text { at Big Trees }\end{array}$ & 111 & 48 & 40.8 & 5,990 & 13,600 & 20,000 & 29,200 & 36,700 \\
\hline 1615 & $\begin{array}{l}\text { Branciforte Creek } \\
\text { at Santa Cruz }\end{array}$ & 17.3 & 40 & 81.0 & 1,610 & 3,290 & 4,670 & 6,660 & 8,290 \\
\hline 1625 & $\begin{array}{l}\text { Pescadero Creek } \\
\text { near Pescadero }\end{array}$ & 45.9 & 38 & 46.0 & 1,980 & 4,720 & 7,150 & 10,800 & 13,800 \\
\hline 1645 & $\begin{array}{l}\text { San Francisquito } \\
\text { Creek at Stanford } \\
\text { University }\end{array}$ & 37.5 & 29 & 154 & 1,980 & 3,280 & 4,100 & 5,100 & 5,900 \\
\hline 1660 & $\begin{array}{l}\text { Matadero Creek } \\
\text { at Palo Alto }\end{array}$ & 7.24 & 19 & 89.1 & 268 & 610 & 861 & 1,170 & 1,390 \\
\hline 1695 & $\begin{array}{l}\text { Saratoga Creek } \\
\text { at Saratoga }\end{array}$ & 9.22 & 45 & 335 & 391 & 856 & 1,320 & 2,150 & 2,980 \\
\hline 1700 & $\begin{array}{l}\text { Coyote Creek } \\
\text { near Madrone }\end{array}$ & 196 & 25 & 38.6 & 5,110 & 9,810 & 11,300 & 13,000 & 14,600 \\
\hline 1735.5 & $\begin{array}{l}\text { Alameda Creek } \\
\text { tributary No. } 2 \\
\text { near Warm Springs }\end{array}$ & .47 & 20 & 1030 & 5 & 16 & 30 & 56 & -- \\
\hline 1740 & $\begin{array}{l}\text { San Antonio Creek } \\
\text { near Suno1 }\end{array}$ & 37.0 & 23 & 166 & 270 & 1,300 & 3,150 & 7,700 & -- \\
\hline 1760 & $\begin{array}{l}\text { Arroyo Mocho } \\
\text { near Livermore }\end{array}$ & 38.2 & 16 & 88.6 & 116 & 600 & 1,280 & 2,370 & -- \\
\hline 1765 & $\begin{array}{l}\text { Arroyo Valle } \\
\text { near Livermore }\end{array}$ & 147 & 16 & 31.7 & 2,790 & 10,400 & 16,700 & 24,100 & 28,700 \\
\hline 1810 & $\begin{array}{l}\text { San Lorenzo Creek } \\
\text { at Hayward }\end{array}$ & 37.5 & 24 & 67.7 & 732 & 1,960 & 3,320 & 5,870 & 8,530 \\
\hline 1821 & $\begin{array}{l}\text { Pinole Creek } \\
\text { at Pinole }\end{array}$ & 10.0 & 22 & 83.0 & 388 & 889 & 1,200 & 1,500 & 1,670 \\
\hline 1825 & $\begin{array}{l}\text { San Ramon Creek } \\
\text { at San Ramon }\end{array}$ & 5.89 & 23 & 102.5 & 304 & 787 & 1,260 & 2,020 & 2,720 \\
\hline 1830 & $\begin{array}{l}\text { San Ramon Creek } \\
\text { at Walnut Creek }\end{array}$ & 50.8 & 20 & 47.4 & 1,380 & 4,320 & 7,230 & 11,800 & 15,800 \\
\hline 1835 & $\begin{array}{l}\text { Walnut Creek } \\
\text { at Walnut Creek }\end{array}$ & 79.2 & 20 & 43.6 & 2,530 & 6,610 & 10,700 & 17,700 & 24,300 \\
\hline 1851.5 & $\begin{array}{l}\text { Horse Creek } \\
\text { near Clayton }\end{array}$ & .20 & 17 & 1730 & 6 & 22 & 35 & -- & -- \\
\hline
\end{tabular}


TABLE 2.--Data used in derivation of flood-frequency relations--Continued

\begin{tabular}{|c|c|c|c|c|c|c|c|c|c|}
\hline \multicolumn{2}{|r|}{ Gaging station } & \multirow{2}{*}{$\begin{array}{c}\text { Drainage } \\
\text { area } \\
(\mathrm{sq} \mathrm{mi})\end{array}$} & \multirow{2}{*}{\begin{tabular}{|c|} 
Mean \\
annual \\
precip- \\
itation \\
(inches) \\
\end{tabular}} & \multirow{2}{*}{\begin{tabular}{|c|} 
Main \\
channel \\
slope \\
(feet \\
per mile)
\end{tabular}} & \multicolumn{5}{|c|}{$\begin{array}{c}\text { Discharge, in cfs, for recurrence intervals } \\
\text { indicated below }\end{array}$} \\
\hline $\begin{array}{l}\text { Number } \\
\text { (fig. 2) }\end{array}$ & Name & & & & $\begin{array}{c}2 \text { years } \\
\left(Q_{2}\right)\end{array}$ & $\begin{array}{c}5 \text { years } \\
\left(Q_{5}\right)\end{array}$ & $\begin{array}{c}10 \text { years } \\
\left(Q_{10}\right)\end{array}$ & $\begin{array}{c}25 \text { years } \\
\left(Q_{25}\right)\end{array}$ & $\begin{array}{c}50 \text { years } \\
\left(Q_{50}\right)\end{array}$ \\
\hline 2630 & $\begin{array}{l}\text { San Luis Creek } \\
\text { near Los Banos }{ }^{2}\end{array}$ & 84.6 & 13 & 52.0 & 370 & 2,700 & 4,100 & 5,300 & -- \\
\hline 2745 & $\begin{array}{l}\text { Orestimba Creek } \\
\text { near Newman }\end{array}$ & 134 & 16 & 43.0 & 1,130 & 3,900 & 6,600 & 10,300 & 13,400 \\
\hline 3375 & $\begin{array}{l}\text { Marsh Creek } \\
\text { near Byron }\end{array}$ & 42.6 & 16 & 63.7 & 538 & 1,940 & 3,700 & 7,240 & 11,100 \\
\hline 4531.5 & $\begin{array}{l}\text { Putah Creek } \\
\text { tributary near } \\
\text { Whispering Pines }\end{array}$ & .24 & 55 & 917 & 33 & 44 & 51 & -- & - \\
\hline 4535 & $\begin{array}{l}\text { Putah Creek } \\
\text { near Guenoc }\end{array}$ & 113 & 52 & 55.1 & 13,300 & 21,300 & 25,700 & 30,200 & 32,800 \\
\hline 4537 & $\begin{array}{l}\text { Cape11 Creek } \\
\text { tributary near } \\
\text { Wooden Valley }{ }^{1}\end{array}$ & .87 & 33 & 476 & 126 & 270 & 400 & -- & -- \\
\hline 4559.5 & $\begin{array}{l}\text { Sulphur Creek } \\
\text { near St. Helena }{ }^{1}\end{array}$ & 4.50 & 40 & 373 & 566 & 801 & 946 & -- & -- \\
\hline 4560 & $\begin{array}{l}\text { Napa River near } \\
\text { St. Helena }\end{array}$ & 81.4 & 48 & 45.7 & 6,470 & 10,200 & 12,100 & 13,800 & 14,700 \\
\hline 4564 & $\begin{array}{l}\text { Lake Hennessey } \\
\text { tributary near } \\
\text { Rutherford }\end{array}$ & 1.04 & 35 & 575 & 59 & 122 & 160 & -- & - \\
\hline 4565 & $\begin{array}{l}\text { Conn Creek near } \\
\text { St. Helena }\end{array}$ & 52.1 & 35 & 140 & 2,540 & 5,250 & 6,900 & 8,610 & 9,610 \\
\hline 4570 & $\begin{array}{l}\text { Dry Creek } \\
\text { near Napa }\end{array}$ & 17.4 & 35 & 71.8 & 1,490 & 2,570 & 3,140 & 3,690 & 3,990 \\
\hline 4585 & $\begin{array}{l}\text { Sonoma Creek } \\
\text { at Agua Caliente }\end{array}$ & 58.3 & 35 & 82.4 & 5,780 & 8,010 & 8,950 & 9,720 & 10,800 \\
\hline 4590 & $\begin{array}{l}\text { Petaluma River } \\
\text { at Petaluma }\end{array}$ & 30.9 & 28 & 95.0 & 1,240 & 1,630 & 1,800 & 2,020 & 2,200 \\
\hline 4600 & $\begin{array}{l}\text { Corte Madera } \\
\text { Creek at Ross }\end{array}$ & 18.1 & 42 & 125 & 2,070 & 3,260 & 3,920 & 4,600 & 5,010 \\
\hline 4632 & $\begin{array}{l}\text { Big Sulphur Creek } \\
\text { near Cloverdale }\end{array}$ & 82.3 & 54 & 147 & 8,790 & 12,400 & 15,400 & 20,000 & 24,000 \\
\hline 4640.5 & $\begin{array}{l}\text { Dry Creek tributary } \\
\text { near Hopland }\end{array}$ & 1.27 & 40 & 722 & 122 & 194 & 267 & -- & -- \\
\hline 4645 & $\begin{array}{l}\text { Dry Creek near } \\
\text { Cloverdale }\end{array}$ & 87.8 & 44 & 31.2 & 8,350 & 13,500 & 17,000 & 20,000 & 23,000 \\
\hline 4650.5 & $\begin{array}{l}\text { Dutcher Creek } \\
\text { near Asti }\end{array}$ & 2.24 & 41 & 184 & 245 & 327 & 365 & -- & -- \\
\hline 4675 & $\begin{array}{l}\text { South Fork } \\
\text { Gualala River } \\
\text { near Annapolis }\end{array}$ & 161 & 60 & 26.2 & 27,100 & 39,800 & 47,000 & 54,900 & 59,900 \\
\hline
\end{tabular}

${ }^{1}$ Also used in regional unit-hydrograph derivation.

${ }^{2}$ Station is located outside area shown in figure 2. 


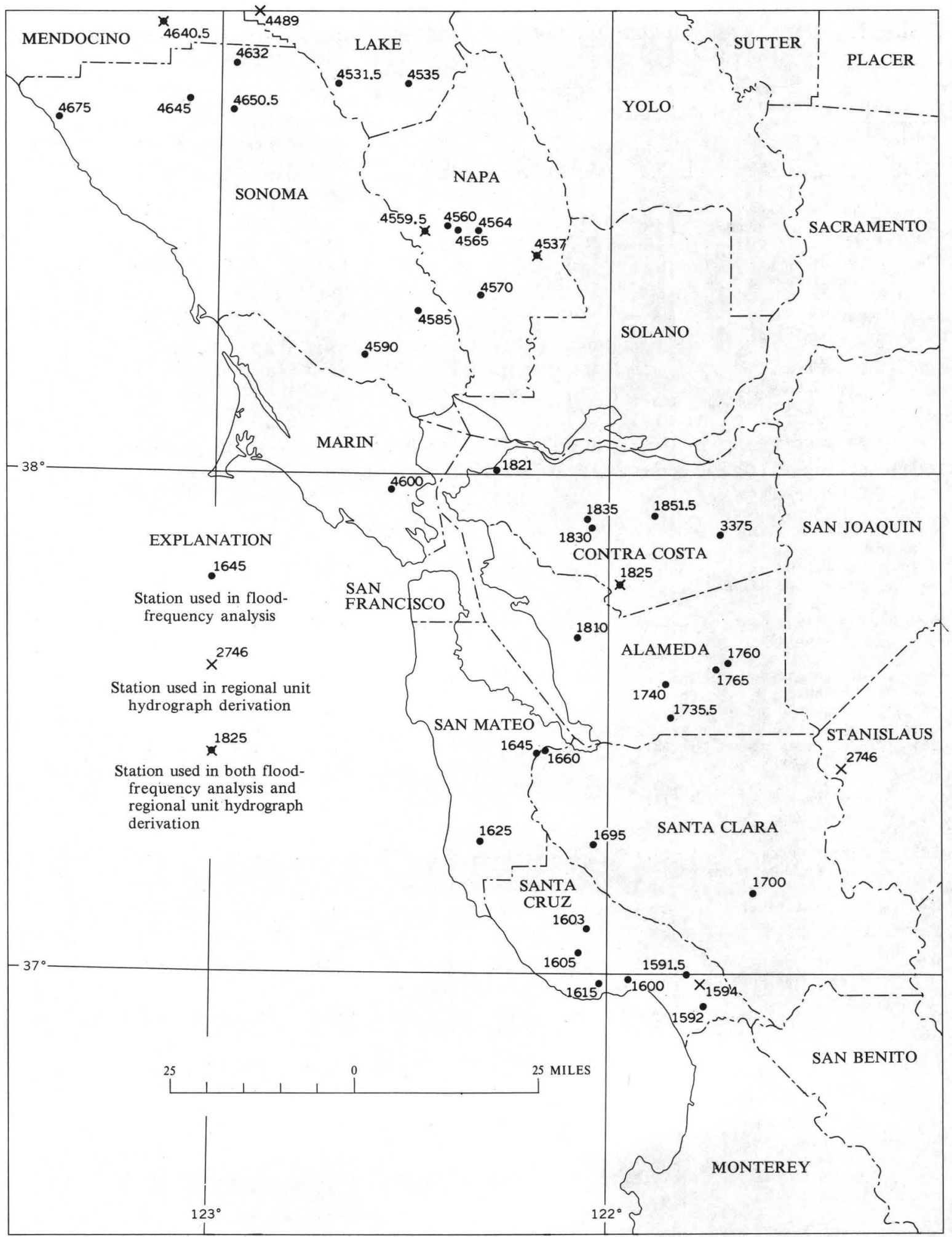

FIGURE 2.--Stream-gaging stations used in flood-frequency analysis and in derivation of regional unit hydrograph. 
At each station the peak discharges for recurrence intervals of 2 , $5,10,25$, and 50 years were computed by fitting a logarithmic Pearson Type III distribution to observed annual peak flows. That procedure is in accordance with the practice recommended by the U.S. Water Resources Council (1967). Because peak discharges were not computed for recurrence intervals that exceeded twice the length of station record, there are gaps in table 2 for peak discharges corresponding to the larger recurrence intervals at small-stream gaging stations. Those stations had short-term records. To obtain regional flood-frequency relations, the peak discharges for each of the five recurrence intervals were correlated with climatologic and topographic parameters, a separate relation being computed for each of the five recurrence intervals.

The only parameters found to have a significant effect on peak discharge were size of drainage area and mean annual basinwide precipitation. Drainage area size was planimetered from topographic maps, and values of mean annual precipitation were obtained from the isohyetal map prepared by Rantz (1971). A basin slope index, commonly used by the Geological Survey, is also shown in table 2. Although not found to be statistically significant in the flood-frequency analysis, the slope index was used later in the unit-hydrograph analysis and is discussed in that section of the report.

The relation between peak discharge and drainage area is obvious--in almost all humid environments, the greater the area contributing runoff, the greater the peak flow. The relation between peak discharge and mean annual basinwide precipitation is less obvious, but it can be explained rationally. Mean annual precipitation is an excellent index of the relative magnitude of storms of any frequency in the region, because the bulk of the annual precipitation occurs there during several general storms each year and the same number of general storms occur at all stations in any given year. Other physiographic, geologic, and climatic parameters undoubtedly affect the flood-frequency relations, but interaction among those parameters obscures their individual effects.

Table 2 shows the ranges in data used to derive the regional floodfrequency relations to be as follows:

Size of drainage area (square miles) 0.2 to 196

Mean annual basinwide precipitation (inches)-_...- 13 to 60

$Q_{2}$ (peak discharge for a 2-year recurrence interval, in cubic feet per second)

$Q_{50}$ (peak discharge for a 50 year recurrence interval, in cubic feet per second) 
The regional relations obtained by multiple regression for streams having natural flow were of the form $Q_{T}=K A_{P}{ }^{b}$; where $Q_{T}$ is the peak discharge, in cfs (cubic feet per second), for a recurrence interval of $T$ years; $A$ is drainage area, in square miles; $P$ is mean annual basinwide precipitation, in inches; and $K, a$, and $b$ are constants. The five regression equations are listed in table 3 , along with their standard errors of estimate. An interesting characteristic of the derived equations is that they show the flood-frequency relations to be much flatter for the humid areas than they are for the drier areas. For example, the ratio of the 50-year peak discharge to the 2-year peak discharge is much smaller for an area whose mean annual precipitation is 60 inches than it is for an area whose mean annual precipitation is 20 inches. That is to be expected, it being almost axiomatic that the more humid the area, the less variability there is in the precipitation and runoff.

To estimate the peak discharge for a given recurrence interval at any site, we first use the equations to compute discharge values for the five recurrence intervals--2, 5, 10, 25, and 50 years. We next plot the five computed discharges at their respective recurrence intervals on probability graph paper. We then fit a smooth curve by eye to the plotted points and extrapolate that curve to the 100 -year recurrence interval. The smooth curve, and not the plotted points, is used to estimate the peak discharge for any desired recurrence interval between 2 and 100 years.

TABLE 3.--Results of flood-frequency analysis--multiple regression equations and associated statistics for peak discharges at selected recurrence intervals

\begin{tabular}{|c|c|c|c|c|c|c|c|}
\hline \multirow{3}{*}{$\begin{array}{l}\text { Recurrence } \\
\text { interval } \\
\text { (years) }\end{array}$} & \multirow{3}{*}{\multicolumn{2}{|c|}{ Multiple regression equation }} & \multirow{3}{*}{$\begin{array}{c}\text { Coefficient of } \\
\text { multiple } \\
\text { correlation }\end{array}$} & \multicolumn{4}{|c|}{ Standard error of estimate } \\
\hline & & & & \multirow{2}{*}{$\begin{array}{c}\text { Logarithmic } \\
\text { units }\end{array}$} & \multicolumn{3}{|c|}{ Percent } \\
\hline & & & & & Plus & Minus & Mean \\
\hline 2 & $Q_{2}=0.069$ & $A^{0.913} P^{1.965}$ & 0.964 & 0.226 & 68.3 & 40.5 & 54.4 \\
\hline 5 & $Q_{5}=2.00$ & $\mathrm{~A}^{0.925} \mathrm{P}^{1.206}$ & .976 & .175 & 49.6 & 33.2 & 41.4 \\
\hline 10 & $Q_{10}=7.38$ & $A^{0.922} P^{0.928}$ & .977 & .168 & 47.2 & 32.1 & 39.6 \\
\hline 25 & $Q_{25}=16.5$ & $A^{0.912} P^{0.797}$ & .950 & .178 & 50.7 & 33.6 & 42.2 \\
\hline 50 & $Q_{50}=69.6$ & $A^{0.847} P^{0.511}$ & .902 & .192 & 55.6 & 35.7 & 45.6 \\
\hline
\end{tabular}

Note.--Q = discharge, in cubic feet per second; $A=$ drainage area, in square miles; and $P=$ mean annual basinwide precipitation, in inches. 


\section{Urbanized Conditions}

As mentioned earlier, peak discharges are usually increased when a basin becomes urbanized. It was also shown earlier that the effect of urbanization depends not only on the degree of urbanization, but also on the characteristics of the urban development. In view of the difficulty of predicting the precise form that development will take when a rural area becomes urbanized, there is little to be gained by becoming deeply involved in general empirical formulas for adjusting flood-frequency curves for the effect of future urbanization, especially since data demonstrating the quantitative effect of urbanization on flood peaks are not available for the study area. After review of the methods used in other parts of the United States for making such adjustments, figure 3 was prepared for use in the San Francisco Bay region. Figure 3 was adapted from a model study by James (1965) for the basin of Morrison Creek in Sacramento County, Calif. If, for example, we compare figure 3 with the results of Anderson's study for northern Virginia (1970), we find fairly close agreement in the two studies, provided we assume from table 1 of our study, that James' "100 percent of the basin developed" is equivalent to Anderson's "50 percent imperviousness."

Sample Problem 1--Flood-Frequency Analysis

To illustrate the procedure for computing peak discharge by the flood-frequency method, we solve the following hypothetical problem.

Given:

Drainage area- $-5.0 \mathrm{sq} \mathrm{mi}$

Mean annual precipitation--40 inches

Degree of development--70 percent of basin urbanized; 70 percent of channels sewered or lined

Required:

Peak discharge for a 25-year recurrence interval

Solution:

The first step is to prepare a flood-frequency curve for the basin under natural conditions.

1. Substitute the given values of drainage area and mean annual precipitation in the equations in table 3 . The discharge values, so computed, will be

$$
\begin{aligned}
& Q_{2}=422 \mathrm{cfs} \\
& Q_{5}=758 \mathrm{cfs} \\
& Q_{10}=998 \mathrm{cfs} \\
& Q_{25}=1,350 \mathrm{cfs} \\
& Q_{50}=1,800 \mathrm{cfs}
\end{aligned}
$$



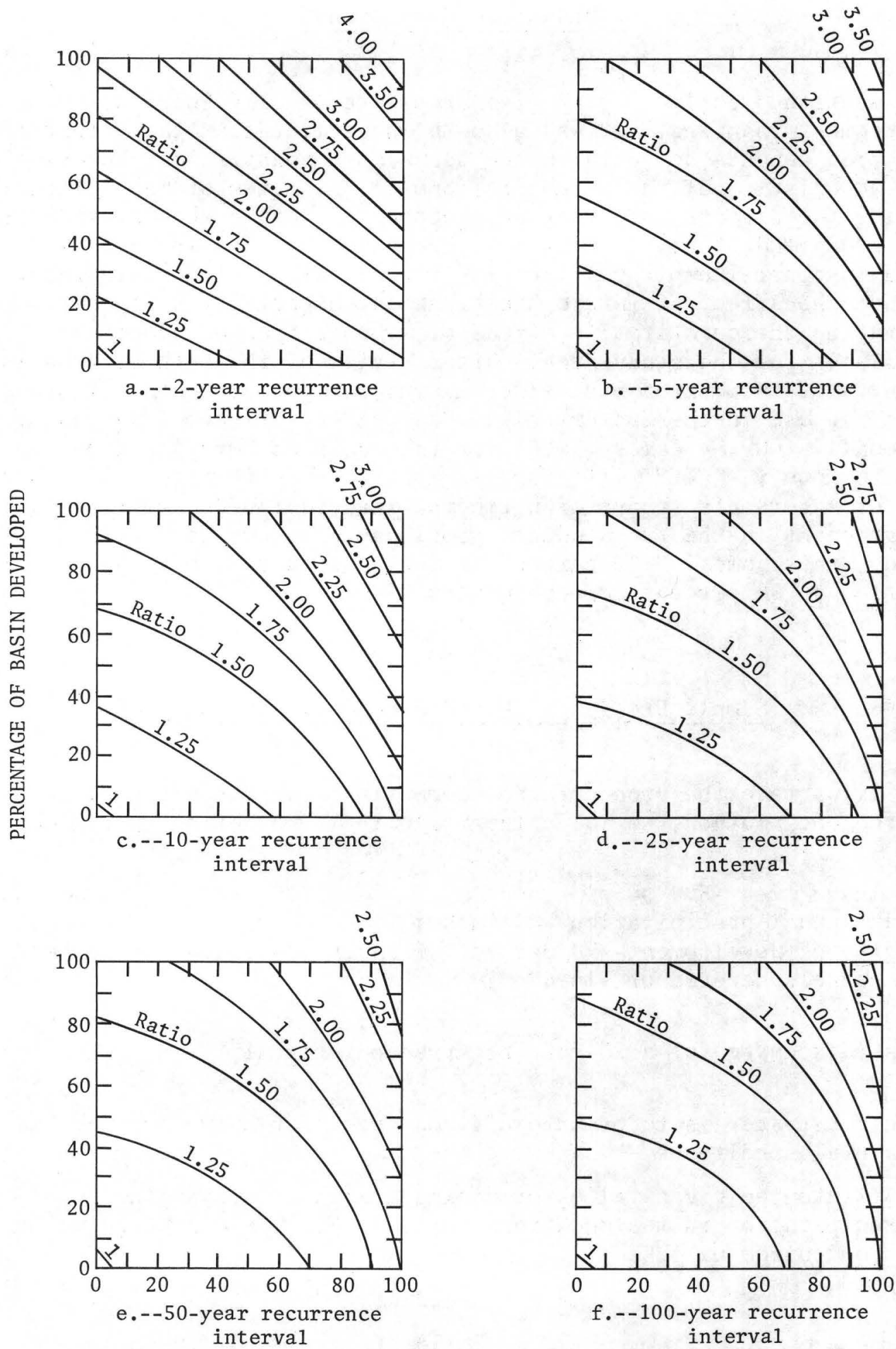

PERCENTAGE OF CHANNELS SEWERED

FIGURE 3.--Ratios of flood-peak magnitude for urbanized basins to that for unurbanized basins--for use with flood-frequency method. 
2. Plot the computed discharge values on probability graph paper (fig. 4).

3. Fit a smooth curve, by eye, to the plotted points.

4. Enter the curve with the required recurrence interval--25 years--and obtain the corresponding discharge under natural conditions-1,390 cfs.

The next step is to adjust the natural discharge for the effect of urbanization.

5. Enter figure $3 d$ with the given degree of development--70 percent urbanized, 70 percent of channels sewered--and obtain the corresponding adjustment coefficient--1.90

6. Multiply the discharge from step 4 by the coefficient from step 5 to obtain the required discharge--2,640 cfs.

$$
1,390 \mathrm{cfs} \times 1.90=2,640 \mathrm{cfs} \text {. }
$$

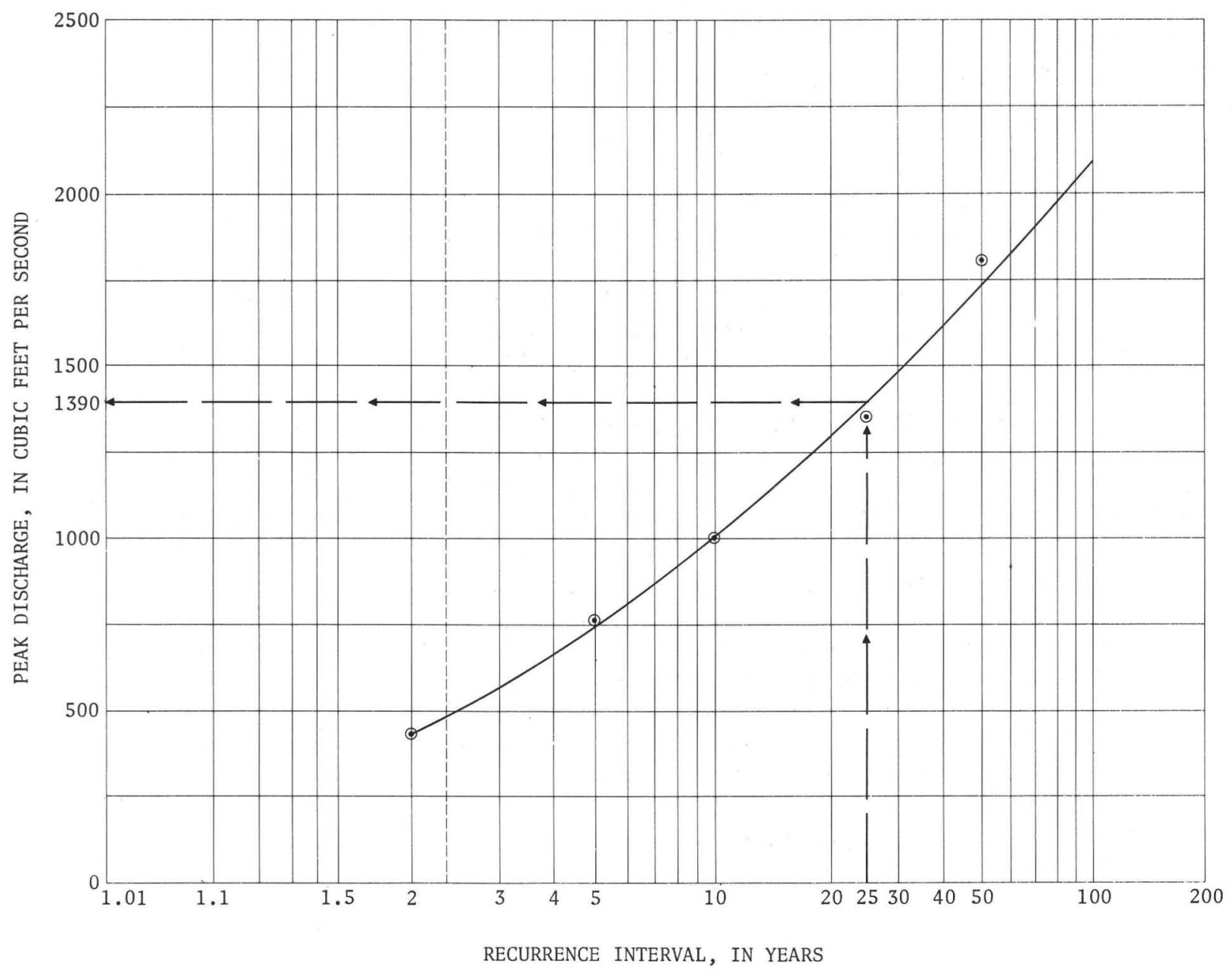

FIGURE 4.--Flood-frequency relation for unurbanized hypothetical watershed of sample problem 1. 


\section{Appraisal of Method}

The flood-frequency method is very simple to apply, but because it gives peak discharges only, it is not satisfactory for use where complete flood hydrographs are also required. The regression equations on which the method is based were derived primarily from data for watersheds larger than 5 square miles; therefore peak discharges determined for large and medium-size watersheds under natural conditions are fairly reliable.

Because of the paucity of data for very small watersheds, the reliability of results obtained for basins smaller than 5 square miles is uncertain. The lack of regional data concerning the quantitative effect of urbanization on flood discharge makes it impossible to evaluate the reliability of figure 3 for predicting that effect.

\section{RATIONAL METHOD}

The Rational Method of computing peak discharge, despite its many shortcomings, is commonly used for small areas because of its simplicity. The equation used in the method is:

$$
Q=C i A,
$$

where $Q$ is the peak runoff rate, in cubic feet per second

$C$ is a dimensionless coefficient whose magnitude depends on basin characteristics

$i$ is the average precipitation intensity, in inches per hour, for a duration equal to time of concentration, and

$A$ is the drainage area, in acres.

The equation is not homogeneous dimensionally, but for all practical purposes the dimensions of the various factors are satisfactory because they are in common use, and the conversion factor that would be needed to provide dimensional homogeneity is nearly unity. (A runoff rate of 1 acre-inch per hour equals $1.008 \mathrm{cfs}-$-the use of a conversion factor of $1 / 1.008$ is unwarranted in so approximate a relation.) Although the Rational Method is commonly applied to areas as large as 5 square miles, it has been recommended that it not be applied to areas any larger than 200 acres (Wright-McLaughlin Engineers, 1969).

The Rational Method is based on the following two assumptions (American Society of Civil Engineers, 1969):

1. The frequencies of peak discharge and peak precipitation rate are identical. 
2. The peak rate of runoff at any site is a direct function of the average precipitation intensity during the time of concentration. Time of concentration is defined as the time required for the runoff to become established, so that flow from the most remote part of the drainage area reaches the site under consideration.

The first assumption is generally true in California. The most intense rainfall usually occurs during general winter storms when antecedent conditions are most favorable for heavy runoff. This is in contrast to many other regions, such as northeastern United States, where the most intense rainfall comes in the summer when in rural areas, at least, antecedent conditions are usually not optimum for heavy runoff. In that part of the country the heaviest runoff generally occurs in late winter or early spring, when storm precipitation is generally less intense, but antecedent conditions are more favorable for heavy runoff.

The second assumption is less satisfactory. The use of average precipitation intensity is generally unsatisfactory because precipitation does not occur at an average rate, and on small areas it is the short intense bursts of precipitation that greatly influence the magnitude of peak discharge. However, the lack of refinement in the use of precipitation data is overshadowed by the uncertainties in selecting appropriate values of the runoff coefficient $C$ for use.

\section{Determination of Coefficient, $C$}

The value of the coefficient $C$ includes the effect of many variables including infiltration, ground slope, ground cover, surface and depression storage, antecedent precipitation and soil moisture, and shape of drainage basin. The coefficient $C$ is commonly assumed to be a constant for any basin, but that obviously cannot be true. Runoff is not a constant percentage of the precipitation, but is the residual quantity of precipitation that remains after such abstractions ("losses") as interception, depression storage, and infiltration. Those losses increase with precipitation increase in minor storms, but at a less than proportionate rate, and tend to remain relatively constant in major storms. Therefore the ratio of runoff to precipitation increases as storm intensity increases, which means that $C$ will be larger for the infrequent major storms than it will be for the more frequent minor storms.

The previously cited ASCE (American Society of Civil Engineers) publication (1969) tabulates suggested ranges of $C$ values for use in drainage design, and those values, with some adjustment to fit the types of development shown in table 1, are listed in column 5 of table 1 . As we would expect, a close relation exists between percentage of impervious area (column 4 of table 1 ) and values of $C$. The percentages of impervious area are plotted against upper and lower values of $C$ in figure 5 and smooth curves (solid lines) have been fitted to the plotted points. Values of $C$ taken from the solid-line curves are tabulated in column 6 of table 1 for use as regional design values. 
In the light of the preceding discussion, where it was shown that values of $C$ increase with recurrence interval, the following method of selecting $C$-values is suggested. From column 4 of table 1 select a percentage of impervious area that is appropriate for the watershed being studied. Enter figure 5 with that percentage to obtain the corresponding $C$-value. For recurrence intervals between 2 and 25 years use a $C$-value between the two solid-line curves, the actual value being based on personal judgment with regard to extent and character of land surfaces. Two broken-line curves have been arbitrarily added to figure 5 to provide values of $C$ for recurrence intervals greater than 25 years. The dotted curve, labeled $C_{50}$, is used for a recurrence interval of 50 years; the dashed curve, labeled $C_{100}$, is used for a recurrence interval of 100 years.

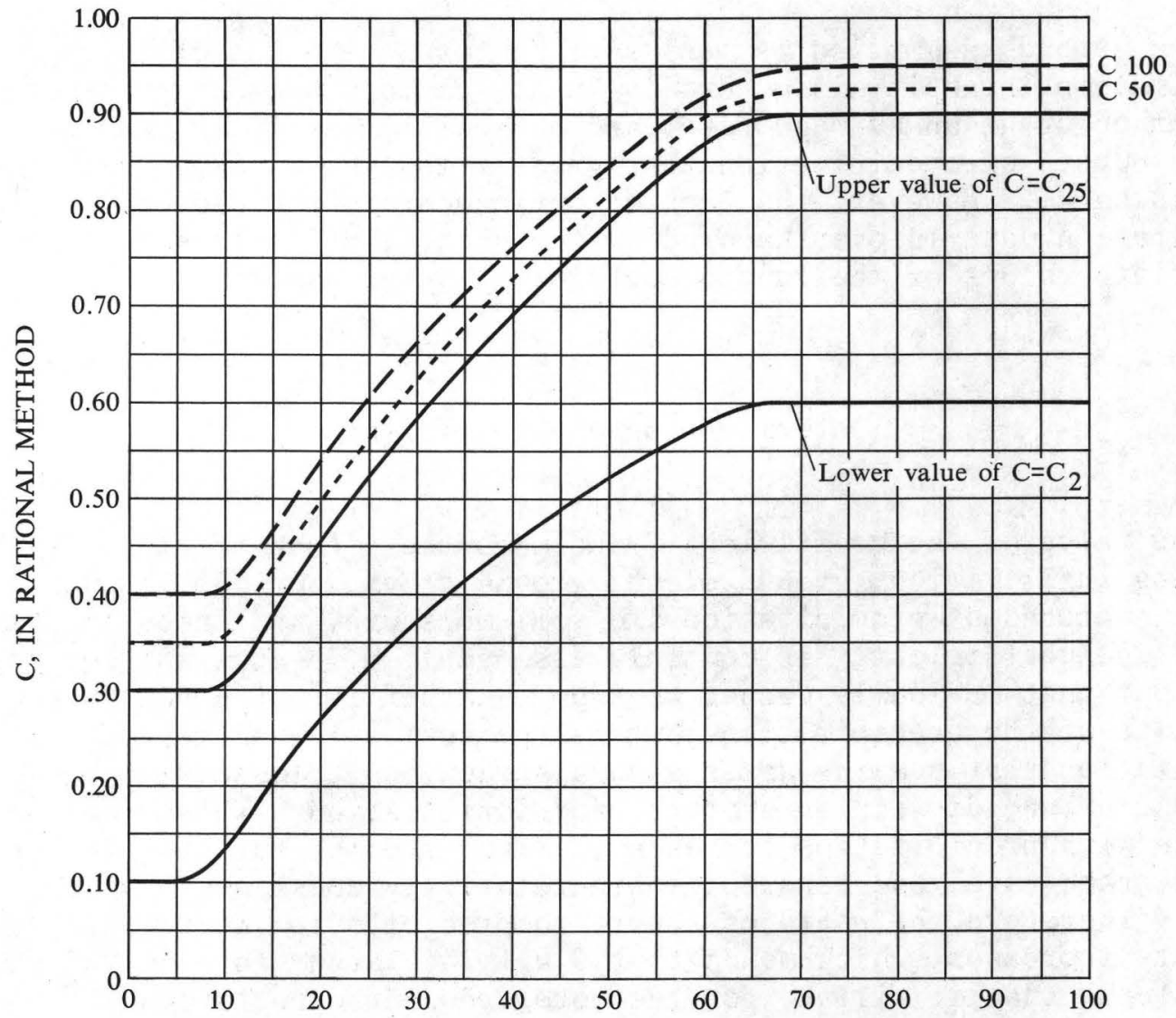

PERCENTAGE OF IMPERVIOUS AREA (FROM COLUMN 4, TABLE 1)

FIGURE 5.--Relation of $C$ to percentage of impervious area--for use in Rational Method. 
As a guide in selecting $C$-values between the two solid-line curves of figure 5 for recurrence intervals of between 2 and 25 years, use may be made of the following list of coefficients that are in current use by drainage designers (American Society of Civil Engineers, 1969).

Character of surface

Runoff coefficient

Pavement :

Asphaltic and concrete-10 0.95

Brick-1..85

Lawns, sandy soil:

F1at (2 percent)

Average (2 to 7 percent)

Steep (7 percent)

Lawns, heavy soil:

F1at (2 percent)

Average (2 to 7 percent)

Steep (7 percent)

\section{Determination of Precipitation Intensity}

In a prior study, Rantz (1971) prepared an isohyetal map and table that give precipitation depth-duration-frequency values for any site in the San Francisco Bay region. The map is used to determine the mean annual precipitation for the site under consideration; the table, a part of which is reproduced here as table 4, is entered with the appropriate value of mean annual precipitation to obtain the storm precipitation corresponding to the desired duration and frequency. The durations given in table 4 range from 5 minutes to 12 hours; the recurrence intervals range from 2 to 100 years. With that information available, all that remains to complete the precipitation aspect of the Rational Method is to determine a methodology for selecting the appropriate duration (time of concentration) and appropriate recurrence interval for use in a given design situation. Selection of the appropriate recurrence interval is left to the designer who must consider the economic, as well as hydraulic, aspect of the design in making his decisions. The American Society of Civil Engineers (1969) reports that the range of recurrence intervals commonly used in engineering offices is as follows:

1. For storm sewers in residential areas, 2 to 15 years (5 years was most common1y reported).

2. For storm sewers in commercial and high-value districts, 10 to 50 years, depending on economic justification.

3. For flood protection works, 50 years or more. 
TABLE 4.--Precipitation depth-duration-frequency data for the San Francisco Bay region

\begin{tabular}{|c|c|c|c|c|c|c|c|c|c|c|c|c|c|}
\hline \multirow{2}{*}{ Duration } & \multirow{2}{*}{$\begin{array}{l}\text { Recur- } \\
\text { rence } \\
\text { interva1 } \\
\text { (years) }\end{array}$} & \multicolumn{12}{|c|}{$\begin{array}{l}\text { Storm precipitation, in inches, corresponding to indicated values of } \\
\text { mean annual precipitation }\left(\mathrm{P}_{\mathrm{MA}}\right) \text {, in inches }\end{array}$} \\
\hline & & 10 & 12 & 14 & 16 & 18 & 20 & 30 & 40 & 50 & 60 & 70 & 80 \\
\hline 5 minutes & $\begin{array}{r}2 \\
5 \\
10 \\
25 \\
50 \\
100\end{array}$ & $\begin{array}{l}0.08 \\
.12 \\
.15 \\
.17 \\
.19 \\
.21\end{array}$ & $\begin{array}{r}0.10 \\
.14 \\
.17 \\
.19 \\
.21 \\
.23\end{array}$ & $\begin{array}{l}0.11 \\
.15 \\
.18 \\
.21 \\
.23 \\
.25\end{array}$ & $\begin{array}{r}0.12 \\
.16 \\
.19 \\
.23 \\
.24 \\
.26\end{array}$ & $\begin{array}{r}0.13 \\
.17 \\
.20 \\
.24 \\
.26 \\
.28\end{array}$ & $\begin{array}{r}0.14 \\
.18 \\
.21 \\
.25 \\
.27 \\
.29\end{array}$ & $\begin{array}{l}0.16 \\
.21 \\
.24 \\
.29 \\
.31 \\
.33\end{array}$ & $\begin{array}{l}0.19 \\
.24 \\
.28 \\
.32 \\
.35 \\
.38\end{array}$ & $\begin{array}{c}0.21 \\
.27 \\
.31 \\
.36 \\
.39 \\
.42\end{array}$ & $\begin{array}{r}0.23 \\
.30 \\
.35 \\
.40 \\
.43 \\
.46\end{array}$ & $\begin{array}{l}0.26 \\
.33 \\
.38 \\
.44 \\
.47 \\
.51\end{array}$ & $\begin{array}{r}0.28 \\
.36 \\
.41 \\
.48 \\
.51 \\
.55\end{array}$ \\
\hline 10 minutes & $\begin{array}{r}2 \\
5 \\
10 \\
25 \\
50 \\
100\end{array}$ & $\begin{array}{l}.13 \\
.19 \\
.23 \\
.27 \\
.30 \\
.32\end{array}$ & $\begin{array}{l}.15 \\
.21 \\
.26 \\
.30 \\
.33 \\
.36\end{array}$ & $\begin{array}{l}.17 \\
.23 \\
.28 \\
.33 \\
.36 \\
.38\end{array}$ & $\begin{array}{l}.18 \\
.25 \\
.30 \\
.35 \\
.38 \\
.41\end{array}$ & $\begin{array}{l}.20 \\
.26 \\
.32 \\
.37 \\
.40 \\
.43\end{array}$ & $\begin{array}{l}.22 \\
.27 \\
.33 \\
.39 \\
.42 \\
.45\end{array}$ & $\begin{array}{l}.25 \\
.32 \\
.38 \\
.45 \\
.48 \\
.52\end{array}$ & $\begin{array}{l}.29 \\
.37 \\
.43 \\
.50 \\
.54 \\
.58\end{array}$ & $\begin{array}{l}.32 \\
.41 \\
.49 \\
.56 \\
.61 \\
.65\end{array}$ & $\begin{array}{l}.36 \\
.46 \\
.54 \\
.62 \\
.67 \\
.72\end{array}$ & $\begin{array}{l}.40 \\
.51 \\
.58 \\
.68 \\
.73 \\
.79\end{array}$ & $\begin{array}{l}.43 \\
.56 \\
.64 \\
.74 \\
.80 \\
.86\end{array}$ \\
\hline 15 minutes & $\begin{array}{r}2 \\
5 \\
10 \\
25 \\
50 \\
100\end{array}$ & $\begin{array}{l}.16 \\
.25 \\
.30 \\
.34 \\
.38 \\
.41\end{array}$ & $\begin{array}{l}.19 \\
.27 \\
.32 \\
.38 \\
.42 \\
.45\end{array}$ & $\begin{array}{l}.21 \\
.29 \\
.35 \\
.42 \\
.45 \\
.48\end{array}$ & $\begin{array}{l}.23 \\
.31 \\
.38 \\
.44 \\
.48 \\
.52\end{array}$ & $\begin{array}{l}.26 \\
.33 \\
.40 \\
.47 \\
.51 \\
.55\end{array}$ & $\begin{array}{l}.27 \\
.35 \\
.42 \\
.49 \\
.53 \\
.57\end{array}$ & $\begin{array}{l}.32 \\
.41 \\
.48 \\
.56 \\
.61 \\
.66\end{array}$ & $\begin{array}{l}.36 \\
.47 \\
.55 \\
.64 \\
.69 \\
.74\end{array}$ & $\begin{array}{l}.41 \\
.52 \\
.62 \\
.71 \\
.77 \\
.83\end{array}$ & $\begin{array}{l}.46 \\
.59 \\
.68 \\
.79 \\
.85 \\
.91\end{array}$ & $\begin{array}{r}.50 \\
.65 \\
.74 \\
.86 \\
.93 \\
1.00\end{array}$ & $\begin{array}{r}.55 \\
.71 \\
.81 \\
.93 \\
1.01 \\
1.08\end{array}$ \\
\hline 30 minutes & $\begin{array}{r}2 \\
5 \\
10 \\
25 \\
50 \\
100\end{array}$ & $\begin{array}{l}.22 \\
.34 \\
.41 \\
.47 \\
.52 \\
.57\end{array}$ & $\begin{array}{l}.26 \\
.37 \\
.45 \\
.53 \\
.58 \\
.62\end{array}$ & $\begin{array}{l}.29 \\
.40 \\
.49 \\
.58 \\
.62 \\
.67\end{array}$ & $\begin{array}{l}.32 \\
.43 \\
.52 \\
.62 \\
.66 \\
.72\end{array}$ & $\begin{array}{l}.36 \\
.46 \\
.55 \\
.65 \\
.70 \\
.76\end{array}$ & $\begin{array}{l}.38 \\
.48 \\
.58 \\
.68 \\
.73 \\
.79\end{array}$ & $\begin{array}{l}.44 \\
.57 \\
.66 \\
.78 \\
.85 \\
.91\end{array}$ & $\begin{array}{r}.51 \\
.65 \\
.76 \\
.88 \\
.96 \\
1.03\end{array}$ & $\begin{array}{r}.57 \\
.73 \\
.85 \\
.99 \\
1.07 \\
1.15\end{array}$ & $\begin{array}{r}.63 \\
.81 \\
.94 \\
1.09 \\
1.18 \\
1.26\end{array}$ & $\begin{array}{r}.70 \\
.90 \\
1.03 \\
1.19 \\
1.29 \\
1.38\end{array}$ & $\begin{array}{r}.76 \\
.98 \\
1.12 \\
1.30 \\
1.40 \\
1.50\end{array}$ \\
\hline 1 hour & $\begin{array}{r}2 \\
5 \\
10 \\
25 \\
50 \\
100\end{array}$ & $\begin{array}{l}.28 \\
.43 \\
.52 \\
.60 \\
.66 \\
.72\end{array}$ & $\begin{array}{l}.33 \\
.47 \\
.57 \\
.67 \\
.73 \\
.79\end{array}$ & $\begin{array}{l}.37 \\
.51 \\
.62 \\
.73 \\
.79 \\
.85\end{array}$ & $\begin{array}{l}.41 \\
.55 \\
.66 \\
.78 \\
.84 \\
.91\end{array}$ & $\begin{array}{l}.45 \\
.58 \\
.70 \\
.82 \\
.89 \\
.96\end{array}$ & $\begin{array}{r}.48 \\
.61 \\
.73 \\
.86 \\
.93 \\
1.00\end{array}$ & $\begin{array}{r}.56 \\
.72 \\
.84 \\
.99 \\
1.07 \\
1.15\end{array}$ & $\begin{array}{r}.64 \\
.82 \\
.96 \\
1.12 \\
1.21 \\
1.30\end{array}$ & $\begin{array}{r}.72 \\
.92 \\
1.08 \\
1.25 \\
1.35 \\
1.45\end{array}$ & $\begin{array}{r}.80 \\
1.03 \\
1.19 \\
1.38 \\
1.49 \\
1.60\end{array}$ & $\begin{array}{l}.88 \\
1.14 \\
1.30 \\
1.51 \\
1.63 \\
1.75\end{array}$ & $\begin{array}{r}.96 \\
1.24 \\
1.42 \\
1.64 \\
1.77 \\
1.90\end{array}$ \\
\hline 2 hours & $\begin{array}{r}2 \\
5 \\
10 \\
25 \\
50 \\
100\end{array}$ & $\begin{array}{r}.45 \\
.67 \\
.74 \\
.90 \\
.98 \\
1.05\end{array}$ & $\begin{array}{r}.51 \\
.72 \\
.79 \\
.94 \\
1.03 \\
1.10\end{array}$ & $\begin{array}{r}.56 \\
.76 \\
.84 \\
.99 \\
1.07 \\
1.15\end{array}$ & $\begin{array}{r}.61 \\
.80 \\
.89 \\
1.03 \\
1.12 \\
1.20\end{array}$ & $\begin{array}{r}.66 \\
.84 \\
.93 \\
1.08 \\
1.16 \\
1.25\end{array}$ & $\begin{array}{r}.70 \\
.88 \\
.97 \\
1.12 \\
1.21 \\
1.30\end{array}$ & $\begin{array}{r}.85 \\
1.07 \\
1.18 \\
1.34 \\
1.44 \\
1.55\end{array}$ & $\begin{array}{l}1.00 \\
1.26 \\
1.39 \\
1.56 \\
1.67 \\
1.80\end{array}$ & $\begin{array}{l}1.15 \\
1.45 \\
1.60 \\
1.78 \\
1.90 \\
2.05\end{array}$ & $\begin{array}{l}1.30 \\
1.64 \\
1.81 \\
2.00 \\
2.13 \\
2.30\end{array}$ & $\begin{array}{l}1.45 \\
1.83 \\
2.02 \\
2.22 \\
2.36 \\
2.55\end{array}$ & $\begin{array}{l}1.60 \\
2.02 \\
2.23 \\
2.44 \\
2.59 \\
2.80\end{array}$ \\
\hline 3 hours & $\begin{array}{r}2 \\
5 \\
10 \\
25 \\
50 \\
100\end{array}$ & $\begin{array}{r}.63 \\
.78 \\
.91 \\
1.03 \\
1.14 \\
1.25\end{array}$ & $\begin{array}{r}.68 \\
.84 \\
.97 \\
1.10 \\
1.21 \\
1.32\end{array}$ & $\begin{array}{r}.72 \\
.89 \\
1.03 \\
1.16 \\
1.28 \\
1.39\end{array}$ & $\begin{array}{r}.77 \\
.95 \\
1.10 \\
1.23 \\
1.34 \\
1.46\end{array}$ & $\begin{array}{r}.81 \\
1.00 \\
1.16 \\
1.29 \\
1.41 \\
1.53\end{array}$ & $\begin{array}{r}.86 \\
1.06 \\
1.22 \\
1.36 \\
1.48 \\
1.60\end{array}$ & $\begin{array}{l}1.09 \\
1.34 \\
1.53 \\
1.69 \\
1.82 \\
1.95\end{array}$ & $\begin{array}{l}1.32 \\
1.62 \\
1.84 \\
2.02 \\
2.16 \\
2.30\end{array}$ & $\begin{array}{l}1.55 \\
1.90 \\
2.15 \\
2.35 \\
2.50 \\
2.65\end{array}$ & $\begin{array}{l}1.78 \\
2.18 \\
2.46 \\
2.68 \\
2.84 \\
3.00\end{array}$ & $\begin{array}{l}2.01 \\
2.46 \\
2.77 \\
3.01 \\
3.18 \\
3.35\end{array}$ & $\begin{array}{l}2.24 \\
2.74 \\
3.08 \\
3.34 \\
3.52 \\
3.70\end{array}$ \\
\hline 6 hours & $\begin{array}{r}2 \\
5 \\
10 \\
25 \\
50 \\
100\end{array}$ & $\begin{array}{r}.91 \\
1.14 \\
1.30 \\
1.46 \\
1.60 \\
1.73\end{array}$ & $\begin{array}{r}.99 \\
1.25 \\
1.42 \\
1.59 \\
1.74 \\
1.88\end{array}$ & $\begin{array}{l}1.07 \\
1.36 \\
1.54 \\
1.72 \\
1.88 \\
2.02\end{array}$ & $\begin{array}{l}1.16 \\
1.46 \\
1.66 \\
1.86 \\
2.02 \\
2.17\end{array}$ & $\begin{array}{l}1.24 \\
1.57 \\
1.78 \\
1.99 \\
2.16 \\
2.31\end{array}$ & $\begin{array}{l}1.32 \\
1.68 \\
1.90 \\
2.12 \\
2.30 \\
2.46\end{array}$ & $\begin{array}{l}1.73 \\
2.22 \\
2.50 \\
2.78 \\
3.00 \\
3.19\end{array}$ & $\begin{array}{l}2.14 \\
2.76 \\
3.10 \\
3.44 \\
3.70 \\
3.92\end{array}$ & $\begin{array}{l}2.55 \\
3.30 \\
3.70 \\
4.10 \\
4.40 \\
4.65\end{array}$ & $\begin{array}{l}2.96 \\
3.84 \\
4.30 \\
4.76 \\
5.10 \\
5.38\end{array}$ & $\begin{array}{l}3.37 \\
4.38 \\
4.90 \\
5.42 \\
5.80 \\
6.11\end{array}$ & $\begin{array}{l}3.78 \\
4.92 \\
5.50 \\
6.08 \\
6.50 \\
6.84\end{array}$ \\
\hline 12 hours & $\begin{array}{r}2 \\
5 \\
10 \\
25 \\
50 \\
100 \\
\end{array}$ & $\begin{array}{l}1.04 \\
1.44 \\
1.70 \\
1.90 \\
2.15 \\
2.35 \\
\end{array}$ & $\begin{array}{l}1.18 \\
1.61 \\
1.88 \\
2.10 \\
2.36 \\
2.57 \\
\end{array}$ & $\begin{array}{l}1.33 \\
1.78 \\
2.06 \\
2.30 \\
2.57 \\
2.79 \\
\end{array}$ & $\begin{array}{l}1.47 \\
1.94 \\
2.24 \\
2.50 \\
2.78 \\
3.01 \\
\end{array}$ & $\begin{array}{l}1.62 \\
2.11 \\
2.42 \\
2.70 \\
2.99 \\
3.23 \\
\end{array}$ & $\begin{array}{l}1.76 \\
2.28 \\
2.60 \\
2.90 \\
3.20 \\
3.45 \\
\end{array}$ & $\begin{array}{l}2.48 \\
3.12 \\
3.50 \\
3.90 \\
4.25 \\
4.55\end{array}$ & $\begin{array}{l}3.20 \\
3.96 \\
4.40 \\
4.90 \\
5.30 \\
5.65\end{array}$ & $\begin{array}{l}3.92 \\
4.80 \\
5.30 \\
5.90 \\
6.35 \\
6.75\end{array}$ & $\begin{array}{l}4.64 \\
5.64 \\
6.20 \\
6.90 \\
7.40 \\
7.85\end{array}$ & $\begin{array}{l}5.36 \\
6.48 \\
7.10 \\
7.90 \\
8.45 \\
8.95\end{array}$ & $\begin{array}{r}6.08 \\
7.32 \\
8.00 \\
8.90 \\
9.50 \\
10.05\end{array}$ \\
\hline
\end{tabular}


The appropriate storm duration to be used for any watershed is equal to the time of concentration, or the time required for water to flow from the most remote part of the basin--from the standpoint of traveltime--to the site under consideration. Time of concentration consists, therefore, of the time required for overland flow from the most remote part of the basin to reach a stream channel or sewer, plus the time required for subsequent channel flow to reach the site under consideration. The latter time can be estimated from the hydraulic properties of the channel by using the Manning equation to first compute channel velocity. In the Manning equation,

$$
V=\frac{1.49}{n} R^{2 / 3} S^{1 / 2}
$$

where $V=$ velocity, in feet per second,

$n=$ Manning roughness coefficient,

$R=$ hydraulic radius at bankfull depth or with pipe flowing full-i.e., area, in square feet, divided by wetted perimeter, in feet, and

$S=$ average streambed slope.

After channel velocity $V$, is determined, the time required for channel flow is computed by dividing channel length, in feet, by channel velocity.

The Manning roughness coefficient, a tabulation of which is found in every handbook used by drainage designers, reflects the condition of the channel. Typical values, showing the range of the coefficient, are as follows :

$$
\begin{array}{ll}
0.013 & \text { Vitreous sewer pipe } \\
0.015 & \text { Concrete-lined channel } \\
0.030 & \text { Natural channel in good condition } \\
0.100 & \text { Weed-choked natural channel. }
\end{array}
$$

To computed time of channel flow must be added the time required for overland flow. The traveltime of overland flow is usually considered to be solely a function of (1) length of overland travel path from the most remote part of the watershed to the intercepting channel or sewer, and (2) average slope of the overland travel path (difference in altitude between highest and lowest points on the overland travel path divided by the length of the overland travel path). However, a recent report by Wright-McLaughlin Engineers (1969) correctly includes the effect of basin characteristics--an index of which is the runoff coefficient $C$--in determining overland time of travel. It is therefore suggested that a graphical relation, adapted and extended from that given in the WrightMcLaughlin report, be used for that purpose. The graph, shown here as figure 6, was produced from the original Wright-McLaughlin version by linear extrapolation of the family of $C$ curves, and semilogarithmic extrapolation of the family of slope curves. 


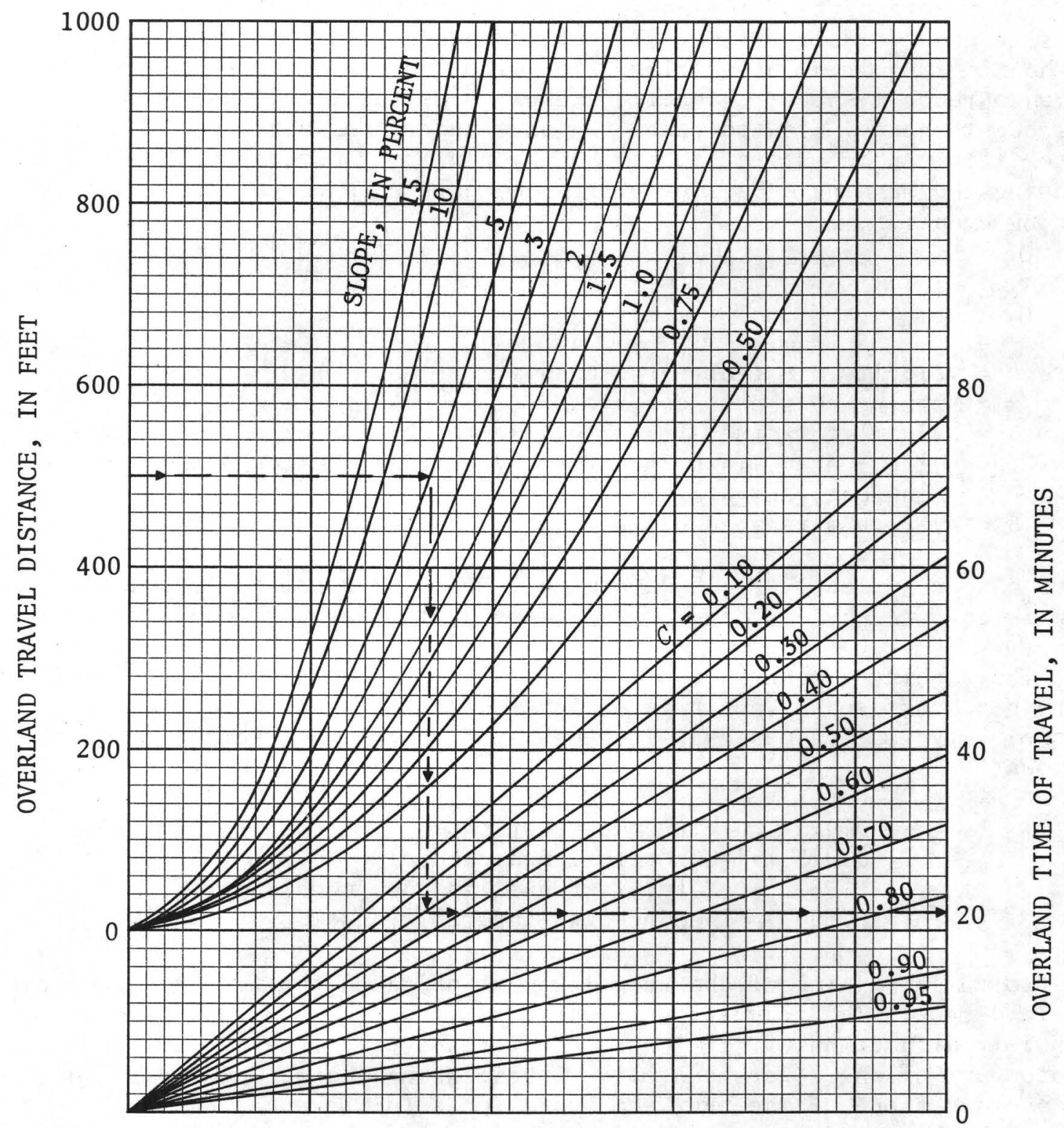

FIGURE 6.--Relation of overland time of travel to overland travel distance, average overland slope, and coefficient $C$--for use in Rational Method. (Based on fig. 3-1, Wright-McLaughlin Engineers, 1969. Adapted and extended by S. E. Rantz.) 
Sample Problem 2--Rational Method

To illustrate the procedure for computing peak discharge by the Rational Method, we solve the following hypothetical problem.

Given:

Drainage area--5.0 sq $\mathrm{mi}(3,200$ acres $)$

Mean annual precipitation--40 inches

Degree of development--Medium density residential development on

70 percent of the watershed; the remaining 30 percent in natural condition.

Overland travel path characteristics

Overland travel distance--500 ft in undeveloped part of watershed Average slope of overland travel path--5 percent

Average channel characteristics downstream from overland travel path Length $(L)--30,000 \mathrm{ft}$

Slope $(S)--4$ percent

Roughness coefficient $(n)--0.030$

Cross-sectional area $(A)--200 \mathrm{sq}$ ft (40 ft wide; $5 \mathrm{ft}$ deep)

Wetted perimeter (WP) $--50 \mathrm{ft}$

Required:

Peak discharge for a 25-year recurrence interva1

Solution:

1. Computation of overland traveltime

(a) According to column 4 of table 1, a natural area has 2 percent of its area impervious.

(b) Enter figure 5 with an impervious area of 2 percent and a 25-year recurrence interval, and read $C=0.30$.

(c) Enter figure 6 with a length of 500 feet, a slope of 5 percent, and a $C$ value of 0.30 , and read overland time of trave 1

$=22$ minutes

2. Computation of channel traveltime

(a) Substitute average channel dimensions and roughness coefficient in formula,

$$
V=\frac{1.49}{n}\left|\frac{A}{W P}\right|^{2 / 3} S^{1 / 2}
$$

Therefore, $V=\frac{1.49}{0.030}\left|\frac{200}{50}\right|^{2 / 3}(0.04)^{1 / 2}$ or

$$
\begin{aligned}
V & =50(4)^{2 / 3}(0.2) \\
& =25.2 \text { feet per second }
\end{aligned}
$$

Note that the computed velocity is inordinately high as a result of simply averaging channel dimensions, but because a flood wave generally travels 1.3 to 1.9 times faster than the water particles, the high value of velocity is acceptable. 
(b) Channel traveltime (minutes) $=\frac{L}{60 \mathrm{~V}}$

$$
\begin{aligned}
& =\frac{30,000}{60 \times 25.2} \\
& =20 \text { minutes }
\end{aligned}
$$

3. Computation of time of concentration $\left(t_{c}\right)$

$t_{c}=$ overland traveltime plus channel traveltime

$=22+20$

$=42$ minutes

4. Computation of coefficient, $C$

(a) According to column 4 of table 1 , a medium density residential development has 25 percent of its area impervious.

(b) Enter figure 5 with an impervious area of 25 percent and a 25-year recurrence interval, and read $C=0.52$. That value of $C$ pertains to the 70 percent of the watershed that is urbanized.

(c) The value of $C$ for the 30 percent of unurbanized watershed is 0.30 (from step $1 \mathrm{~b}$, above).

(d) The weighted value of $C$ for the entire watershed is therefore,

$$
(0.7 \times 0.52)+(0.3 \times 0.30) \text {, or } 0.45
$$

5. Computation of precipitation intensity (i)

(a) We require the precipitation intensity corresponding to a recurrence interval of 25 years and a duration equal to the time of concentration, 42 minutes.

(b) Table 4 shows that in an area whose mean annual precipitation is 40 inches, the 25-year precipitation for 30 minutes is 0.88 inch, and that for 60 minutes is 1.12 inches.

(c) By interpolation between those two values, the 42-minute precipitation depth is,

$$
0.88+0.24\left(\frac{12}{30}\right)=0.98 \text { inch }
$$

(d) Expressed in inches per hour, 0.98 inch in 42 minutes equals

$$
0.98 \times \frac{60}{42}=1.40 \text { inches per hour }
$$

6. Computation of peak discharge (Q)

$$
\begin{aligned}
Q & =C i A \\
& =0.45 \times 1.40 \times 3,200 \text { acres } \\
& =2,020 \mathrm{cfs} .
\end{aligned}
$$


7. Discussion of results: In the sample problem above, we used a drainage area of 5 square miles, a mean annual precipitation of 40 inches, and a degree of watershed urbanization of 70 percent, for consistency with the data used in sample problem 1 to illustrate the use of flood-frequency analysis. Although the results obtained by the two methods agree fairly well, they actually are not comparable. Our flood-frequency method uses only the parameters of drainage area, mean annual precipitation, and percentage of developed area, with the tacit assumption that all other parameters affecting peak discharge in the San Francisco Bay region are related to those three. The Rational Method uses many more parameters, as we have seen, all of which have a direct bearing on the results obtained. This is not to imply that the Rational Method is the superior one, but merely to point out that the peak discharges for a watershed computed by the two methods may differ considerably.

\section{Appraisal of Method}

The Rational Method is a more subjective procedure than the floodfrequency method, but it too is simple to apply. Like the flood-frequency method, it provides a value of peak discharge only, and therefore it is not satisfactory for use where complete flood hydrographs are also required. The Rational Method is intended for use with small simple watersheds, no larger than 5 square miles and preferably no larger than 0.5 square mile. Even a small watershed offers complications if its mainstream has one or more tributaries of significant size, because ideally, the Rational Method should be applied separately to each tributary stream, and the tributary flows then routed down the main channe1. The Rational Method, however, as mentioned above, provides no complete hydrographs for direct routing to the site under consideration.

Although the Rational Method is perhaps the most widely used method for designing storm drainage for small watersheds, there is virtually no way of objectively testing the reliability of the method. Other theoretical shortcomings of the method, with regard to the use of average precipitation intensity and the use of a proportional runoff coefficient $(C)$, were briefly discussed earlier. 
The unit hydrograph is a widely used device for relating runoff to storm precipitation and is described in all standard hydrology texts (for example, Linsley, Kohler, and Paulhus, 1949, p. 444-459). The unit hydrograph shows the time distribution of surface runoff resulting from a storm that produces 1 inch of rainfall excess over the watershed in some selected interval of time. Rainfall excess is defined as that part of the rainfall that is available to produce surface runoff, after the demands of infiltration and surface retention have been met. That part of the precipitation that infiltrates into the ground or is retained above ground is collectively known as water loss. The time interval or duration used for the 1 inch of rainfall excess varies with basin size and with the time response of runoff to rainfall. It may be as short as 1 minute for a sma11 experimental plot or as 1 ong as 24 hours for a large slow-rising river, but in practice it generally ranges between 5 minutes and 6 hours. Given the unit hydrograph for a watershed and the precipitation distribution for a given storm, the hydrologist can produce the resulting hydrograph of surface runoff.

The unit hydrograph for a gaged watershed can be derived with relative ease from observed hydrographs and the record from a recording raingage in the basin. From the characteristics of the unit hydrographs for several gaged watersheds in a region, it is then possible to derive synthetic unit hydrographs for use with ungaged watersheds in the region. The principal characteristic that distinguishes one unit hydrograph from another is lag, which is a measure of the time response of runoff to rainfa11. Lag will be discussed shortly.

The brief introduction above gives some insight into the approach that was taken for this part of the study, the principal elements of which are as follows:

1. Derive synthetic unit hydrographs for use with ungaged unurbanized watersheds in the San Francisco Bay region. (Virtually no data are available for urbanized watersheds in the region.)

2. Derive storm sequences of various recurrence intervals for use with watersheds having various values of $1 \mathrm{ag}$.

3. Derive rates of water loss from design storms for use with unurbanized watersheds.

4. Determine base flow for various recurrence intervals.

With the above four elements, design hydrographs for various recurrence intervals can be computed for any unurbanized watershed in the region. The final phase of the unit-hydrograph study involved the development of adjustments to the synthetic unit hydrograph and to the water-1oss rates for the effect of various degrees of urbanization. 
Synthetic Unit Hydrographs for Unurbanized Watersheds

The streamflow and precipitation records required for constructing unit hydrographs were available for seven stream-gaging stations and for a total of 53 storms. The stations, shown with identifying number in figure 2, are listed in table 5 along with their pertinent basin characteristics. The streamflow records for four of the stations are sufficiently long for them to have been used in the flood-frequency analysis described earlier; the remaining three stations had records for less than 5 years.

For the purpose of simplifying computations it was decided early in the study to construct all unit hydrographs as triangles. That is not a new procedure; the U.S. Soil Conservation Service (1957) has for many years used a synthetic triangular unit hydrograph whose relative dimensions are unvarying for any basin in the Nation. Rather than use so generalized an approach for this study, our planned procedure was to first compute triangular unit hydrographs for all storms at the seven gaging stations. The next step was to average the unit hydrographs at each station. The final step was to use the characteristics of the average unit hydrographs to derive the dimensions of triangular synthetic unit hydrographs for use with ungaged unurbanized watersheds in the San Francisco Bay region.

TABLE 5.--Basin characteristics and IUH properties of watersheds used in the unit-hydrograph study

\begin{tabular}{|c|c|c|c|c|c|c|c|c|c|}
\hline \multicolumn{2}{|r|}{ Gaging station } & \multirow{2}{*}{$\begin{array}{l}\text { Drainage } \\
\text { area, A } \\
(\mathrm{sq} \mathrm{mi})\end{array}$} & \multirow{2}{*}{$\begin{array}{l}\text { Main } \\
\text { channe1 } \\
\begin{array}{c}\text { length, L } \\
(\mathrm{mi})\end{array}\end{array}$} & \multirow{2}{*}{$\begin{array}{c}\text { Main } \\
\text { channel } \\
\text { slope, S } \\
\text { (feet per } \\
\text { mi) }\end{array}$} & \multirow[b]{2}{*}{$\mathrm{A} / \mathrm{S} \frac{1}{2}$} & \multicolumn{4}{|c|}{ Properties of IUH } \\
\hline $\begin{array}{l}\text { Number } \\
\text { (fig. 2) }\end{array}$ & Name & & & & & $\begin{array}{l}\text { Lag } \\
(\mathrm{hr})\end{array}$ & $\begin{array}{c}{ }^{\mathrm{T}} \mathrm{B}_{\mathrm{I}} \\
(\mathrm{hr})\end{array}$ & ${ }^{\mathrm{T}_{\mathrm{P}}}{ }_{\mathrm{I}}$ & $\begin{array}{l}\text { Peak } \\
\text { discharge } \\
\quad \text { (cfs) }\end{array}$ \\
\hline 1594 & $\begin{array}{l}\text { Green Valley Creek } \\
\text { near Corralitos }\end{array}$ & 7.05 & 6.95 & 104.3 & 0.690 & 2.625 & 6.75 & 1.125 & 1,348 \\
\hline 1825 & $\begin{array}{l}\text { San Ramon Creek } \\
\text { at San Ramon }\end{array}$ & 5.89 & 5.72 & 102.5 & .582 & 1.542 & 4.00 & .625 & 1,850 \\
\hline 2746 & $\begin{array}{c}\text { De1 Puerto Creek } \\
\text { tributary No. } 1 \\
\text { near Patterson }\end{array}$ & .71 & 1.55 & 787 & .025 & 1.125 & 3.15 & .225 & 291 \\
\hline 4489 & $\begin{array}{l}\text { Highland Creek above } \\
\text { Highland Creek Dam }\end{array}$ & 11.9 & 5.30 & 114.2 & 1.113 & 3.250 & 8.75 & 1.000 & 1,755 \\
\hline 4537 & $\begin{array}{c}\text { Capell Creek tributary } \\
\text { near Wooden Valley }\end{array}$ & .87 & 1.96 & 476 & .040 & 1.375 & 3.75 & .375 & 300 \\
\hline 4559.5 & $\begin{array}{l}\text { Sulphur Creek near } \\
\text { St. Helena }\end{array}$ & 4.50 & 4.19 & 373 & .233 & 2.358 & 6.20 & .875 & 937 \\
\hline 4640.5 & $\begin{array}{l}\text { Dry Creek tributary } \\
\text { near Hopland }\end{array}$ & 1.27 & 1.92 & 722 & .047 & 1.708 & 4.50 & .625 & 364 \\
\hline
\end{tabular}


As mentioned earlier, the principal distinguishing characteristic of a unit hydrograph is lag, which is a measure of the time response of runoff to rainfa11. Lag may be measured in several ways, but the most conservative or unvarying value of lag for a watershed is that measured from the center of gravity of the runoff-producing rainfall to the center of gravity of the hydrograph of surface runoff. If the unit hydrograph is a triangle, the computation of lag is simplified, because the properties of a triangle are such that the time from the start of surface runoff to the center of gravity of the hydrograph is equal to $\left(T_{P}+T_{B}\right) / 3$ (figure 7 ). Lag is therefore equal to $\left(T_{P}+T_{B}\right) / 3-(d / 2)$. Furthermore, the area of the triangular unit hydrograph is equivalent to 1 inch of runoff over the basin, which expressed in cfs-hours, equals 645.336 times drainage area $(A)$ in square miles. Therefore the peak of the unit hydrograph, in cfs, equals

$$
\frac{1290.67 \times A(\mathrm{sq} \mathrm{mi})}{T_{B}(\mathrm{hrs})}
$$

Triangular unit hydrographs were derived for all storms at each station using a value of 15 minutes for $d$, the time increment of precipitation. It is not uncommon to find some watersheds where peak discharge of the unit hydrograph and lag vary systematically with stormprecipitation volume or intensity. No such relation was found at any of the seven watersheds studied, and therefore at each station the derived unit hydrographs were simply averaged.

In applying a unit hydrograph to storm rainfall, the magnitude of the time increment of rainfal1, $d$, that is used for a basin, will depend on the magnitude of $T_{P}$, $d$ being greater for the greater values of $T_{P}$. Because of the variability of $d$, it was considered expedient to convert the average 15-minute unit hydrographs (TUH) at each station to instantaneous unit hydrographs (IUH) before deriving triangular synthetic unit hydrographs. (The IUH, actually a hydrologic abstraction wherein 1 inch of rainfall excess occurs in an infinitessimal time period, $d$, is a convenient hydrologic tool for the purpose used here.) The transformation from 15-minute TUH to IUH is made by subtracting $d$ (15 minutes) from ${ }_{B}$, and subtracting $d / 2$ (7.5 minutes) from $T_{P}$. The resulting unit hydrograph is not the true IUH, but for small values of $d$ (less than 1 hour), it very closely approximates the true IUH. The value of lag remains unchanged, as it should, in the transformation. The properties of the average instantaneous triangular unit hydrographs, so computed for each of the seven stations, are listed in table 5 . 
The next step in deriving synthetic unit hydrographs for the region is to relate lag to basin characteristics for the seven stations. Lag, being a reflection of basin storage and basin traveltime, is a function of such parameters as basin size, shape, slope, and drainage pattern. Nevertheless it is customary in hydrologic studies to simply relate lag to basin length (measured along the main channel) and to the square root of an index of basin slope. A slope index is used for convenience because of the tediousness of computing basin slope itself. The slope index customarily used by the Geological Survey is the average slope of the main channel, expressed in feet per mile, between points 10 percent and 85 percent of the distance from the gaging site or study site to the basin divide. It is obvious that the use of only channel length and slope provides an index of basin traveltime, but may reflect poorly the effect of basin storage. Because data for only seven stations were available for relating lag to basin characteristics, the number of characteristics that could be used in a correlation was limited. Two correlations were investigated--lag versus the quotient of basin length divided by the square root of the slope index $\left(L / S^{\frac{1}{2}}\right)$, and lag versus the quotient of drainage area divided by the square root of the slope index $\left(A / S^{\frac{1}{2}}\right)$. The relationship using $A / S^{\frac{1}{2}}$ was significantly the better of the two, and was adopted for determining lag for ungaged unurbanized watersheds.

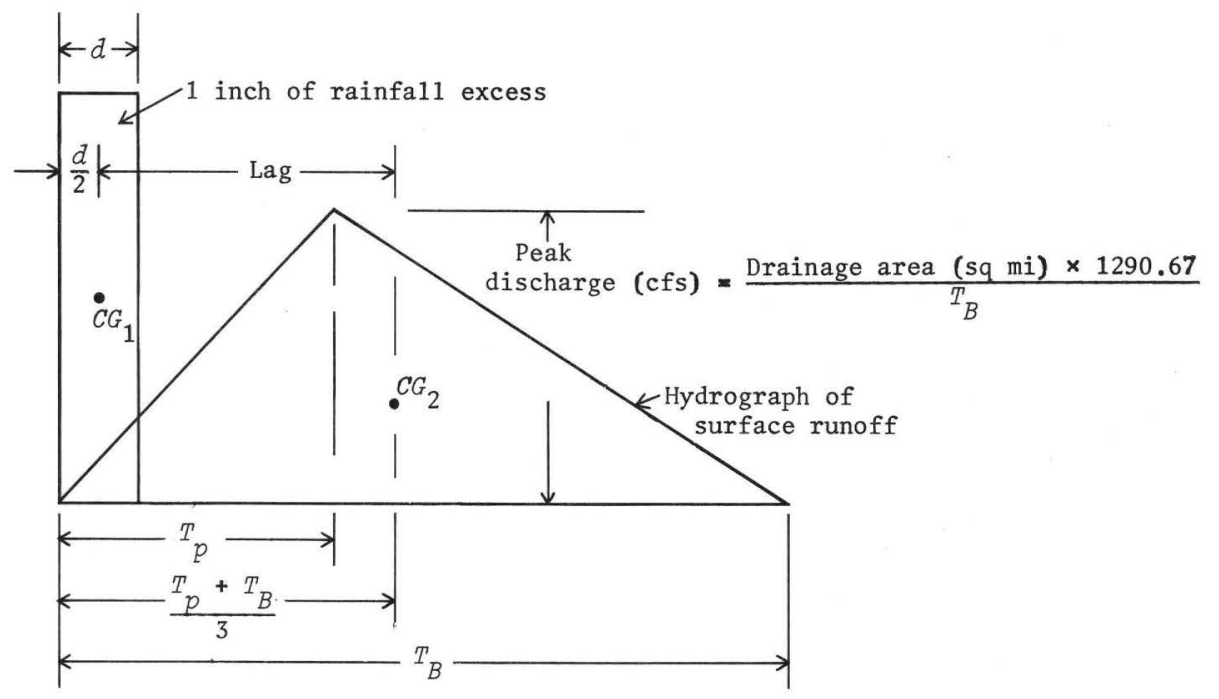

TIME, IN HOURS $\longrightarrow$

EXPLANATION

\footnotetext{
$d=$ time increment, in hours, during which 1 inch of rainfall excess occurs

$C G_{1}=$ center of gravity of time increment, $d$

$C G_{2}=$ center of gravity of triangular unit hydrograph

$T_{p}=$ time, in hours, from start of rainfall excess to unithydrograph peak

$T_{B}=$ base of unit hydrograph, in hours
}

FIGURE 7.--Basic triangular unit hydrograph. 
Figure $8(a)$ shows the equation and line of relation between lag and $A / S^{\frac{1}{2}}$. More often than not, in deriving a regional synthetic unit hydrograph, $T_{B}$ and $T_{P}$ are found to be directly proportional to the basin lag. Such was not the case in this study, and figure $8(\mathrm{~b})$ shows the equation and line of relation between $T_{B_{I}}$ (subscript $I$ refers to IUH) and $A / S^{\frac{1}{2}}$. With lag and $T_{B_{I}}$ determined from figure 8 , it is a simple matter to compute ${ }^{T} P_{I}$ from the basic equation for lag,

$$
\text { Lag }=\left(T_{P_{I}}+T_{B_{I}}\right) / 3
$$

Table 6 summarizes the equations for computing the dimensions of the synthetic triangular unit hydrograph for an unurbanized watershed, whose drainage area and slope index are either known or can be determined from a topographic map.

In applying the unit hydrograph to storm precipitation, the time increment of rainfall excess, $d$, to be used is one whose value is between $1 / 5$ and $1 / 3$ of $T_{P}$. The equations for $T_{B}$ and $T_{P}$ then become

$$
\begin{aligned}
& T_{B}=T_{B}+d \text {, and } \\
& T_{P}=T_{P_{I}}+d / 2 .
\end{aligned}
$$

TABLE 6.--Equations for computing dimensions of triangular unit hydrographs for use with unurbanized watersheds in the San Francisco Bay region

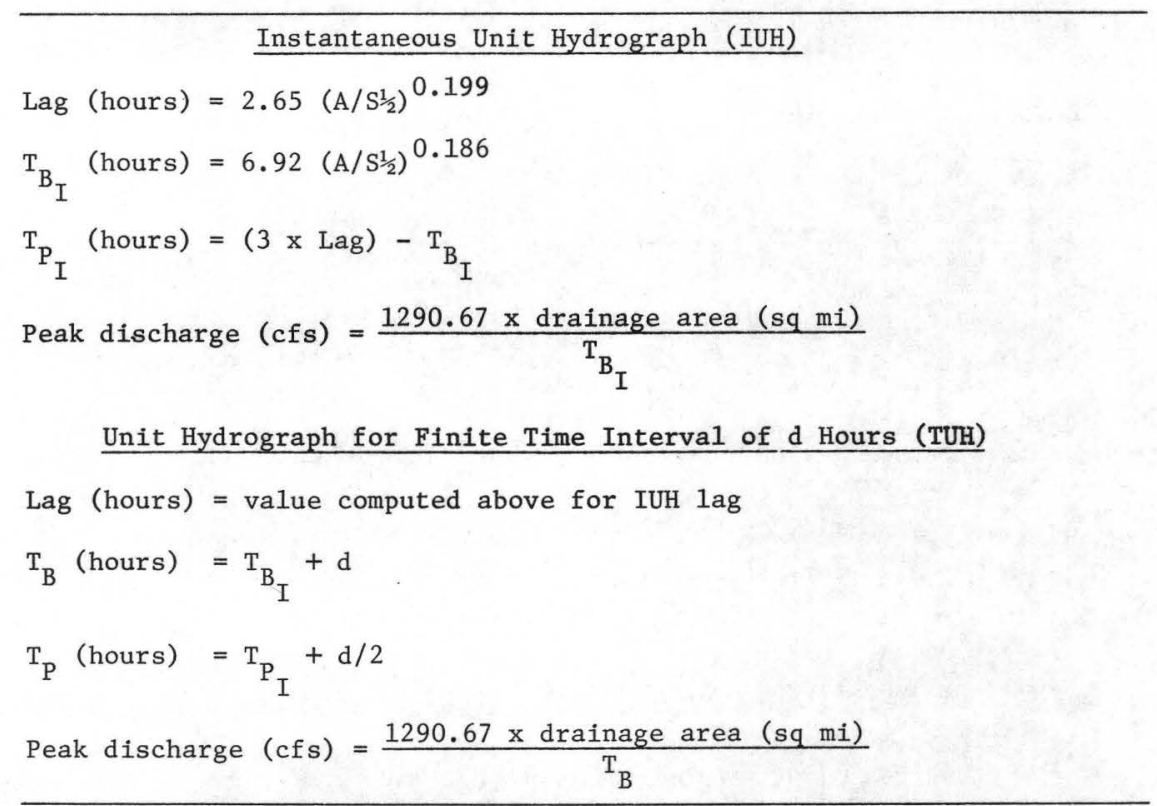




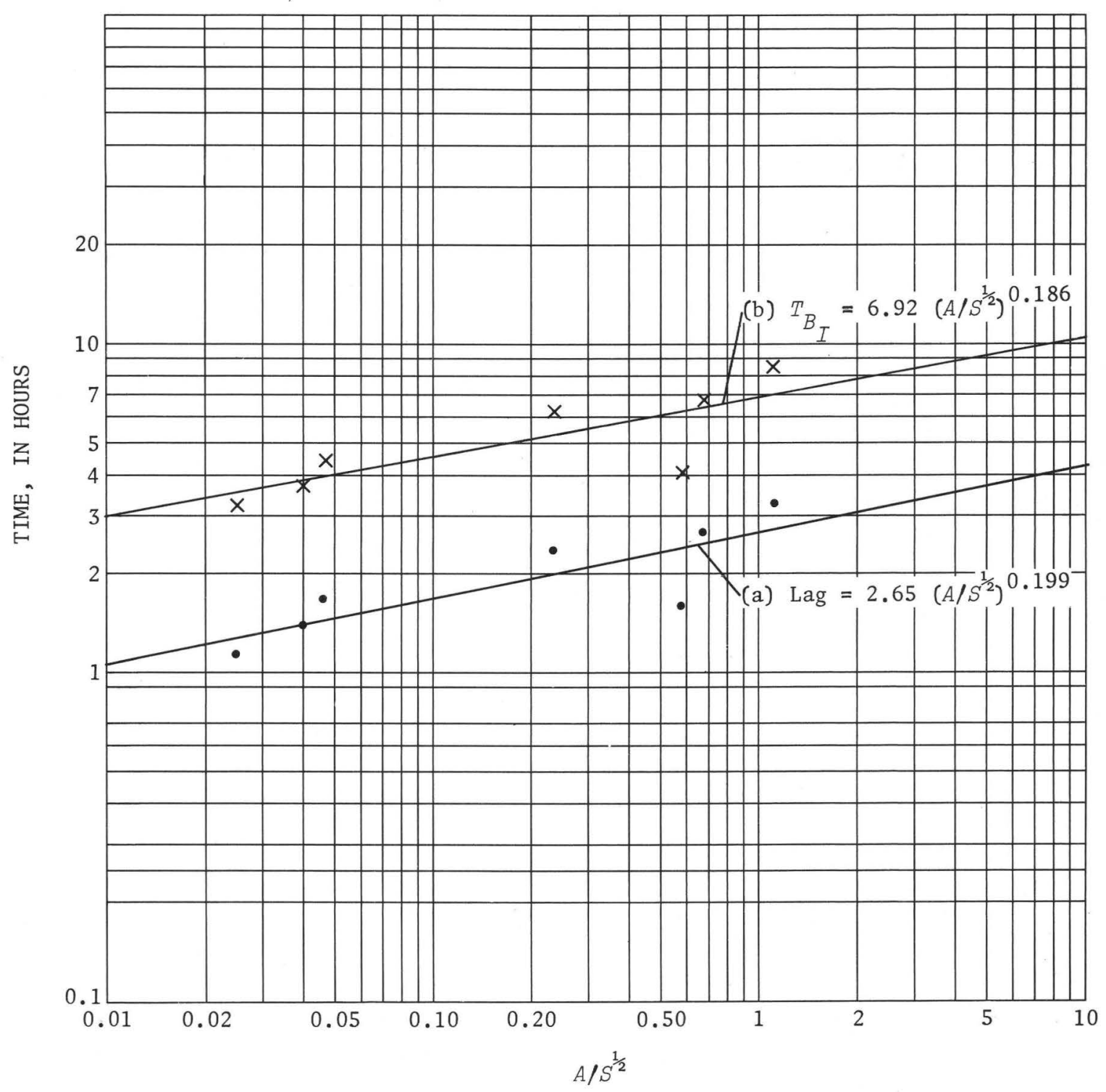

FIGURE 8.--Instantaneous unit-hydrograph relations for unurbanized watersheds: (a) Lag versus $A / S^{\frac{1}{2}}$; (b) $T_{B_{I}}$ versus $A / S^{\frac{1}{2}}$. 


\section{Design Storms for Various Recurrence Intervals}

After the synthetic triangular unit hydrograph (TUH) has been computed for a watershed, the next step is to determine the design storms for various recurrence intervals, to which the unit hydrograph will be applied. This involves use of the isohyetal map for the San Francisco Bay region and table 4. The isohyetal map shows mean annual precipitation for the watershed under consideration; table 4 gives the storm precipitation for various recurrence intervals and durations corresponding to that value of mean annual precipitation. A11 that remains then is to determine the appropriate storm duration for use, and the time distribution of storm precipitation during that duration period.

Peak discharges in any year invariably occur during prolonged storms as a direct result of relatively short periods of intense rainfall. Channels are generally carrying significant flow at the onset of the intense rainfall, and the resulting heavy runoff augments the flow already in the channels. This antecedent flow, which will hereafter be referred to as base flow, will be discussed quantitatively in a later section. At this point we are concerned generally with the short-period heavy runoff, and specifically with deciding on the critical storm duration to be used with our unit hydrograph. Experience indicates that the critical duration should be something greater than basin lag, and study of the rainfall and runoff data for the region suggests that the duration for use be the next hour larger than basin 1ag. For example, for values of lag smaller than 1 hour, use a storm duration, $D$, in table 4 , equal to one hour; for a lag between 1 and 2 hours, use $D=2$ hours; and so on. If the value of $1 \mathrm{ag}$ is exactly an even hour, or very nearly so, use a duration equal to the next larger hour--for example, for a value of lag between 2.90 and 3.00 hours, use $D=4$ hours.

After the appropriate duration, $D$, has been selected, we enter table 4 with that value of $D$ and the required recurrence interval, and read the corresponding value of total storm precipitation.

The next step is to distribute the total precipitation during the storm period by time increments equal to $d$. It will be recalled that the value of $d$ selected should be between $1 / 3$ and $1 / 5$ of the value of $T_{P}$ of the unit hydrograph. For example, if $T_{P}=1$ hour, a value of 15 minutes should be selected for $d$, although a value of 20 minutes would also be acceptable. Table 7 shows recommended cumulative time distributions of precipitation for storm durations, $D$, ranging from 1 to 6 hours. The table will be used for all recurrence intervals. Table 7 is based on a time distribution that is used by the U.S. Soil Conservation Service (1957, fig. 3.21-5). It can be seen in the table that distributions for various values of $D$ differ little from each other. The differences that do appear represent adjustments to the basic Soil Conservation Service distribution that were made to ensure consistency with table 4. For example, if table 4 showed the 15-minute precipitation for a 25-year recurrence interval to be $0.60 \mathrm{inch}$, we wish to make sure that within the 2-hour precipitation for a 25-year recurrence interval, no 15-minute periods had more than 0.60 inch of precipitation. 
TABLE 7.--Cumulative time distributions of precipitation for various storm durations

\begin{tabular}{|c|c|c|c|c|c|c|}
\hline \multirow{2}{*}{$\begin{array}{l}\text { mula- } \\
\text { tive } \\
\text { percentage } \\
\text { of time }\end{array}$} & \multicolumn{6}{|c|}{$\begin{array}{l}\text { Cumulative percentage of precipitation within } \\
\text { storms of indicated duration }(D) \text {, in hours }\end{array}$} \\
\hline & 1 & 2 & 3 & 4 & 5 & 6 \\
\hline 0 & 0 & 0 & 0 & 0 & 0 & 0 \\
\hline 10 & 5 & 5 & 6 & 6 & 7 & 7 \\
\hline 20 & 10 & 10 & 12 & 13 & 15 & 16 \\
\hline 25 & 14 & 14 & 16 & 18 & 20 & 22 \\
\hline 30 & 19 & 19 & 21 & 23 & 25 & 27 \\
\hline 35 & 35 & 35 & 36 & 37 & 38 & 39 \\
\hline 40 & 52 & 52 & 52 & 52 & 52 & 52 \\
\hline 45 & 61 & 61 & 61 & 60 & 60 & 59 \\
\hline 50 & 70 & 70 & 69 & 68 & 67 & 66 \\
\hline 55 & 75 & 75 & 73 & 72 & 71 & 70 \\
\hline 60 & 79 & 79 & 76 & 75 & 74 & 74 \\
\hline 70 & 85 & 85 & 82 & 82 & 81 & 80 \\
\hline 80 & 91 & 91 & 88 & 88 & 88 & 87 \\
\hline 90 & 96 & 96 & 94 & 94 & 94 & 94 \\
\hline 100 & 100 & 100 & 100 & 100 & 100 & 100 \\
\hline
\end{tabular}

To explain the use of table 7 with an example, assume that our analysis indicates the use of a storm duration, $D$, of 3 hours, and a time increment, $d$, of 15 minutes. Assume further that table 4 indicates the 3-hour storm total for the desired recurrence interval to be 2.02 inches. Because 15 minutes is 8.33 percent of 3 hours, we will use time increments of 8.33 percent, as shown in the tabulation below. The cumulative percentages of precipitation shown in that tabulation are obtained by interpolation of values in the fourth column $(D=3$ hours $)$ of table 7 . From the cumulative percentages of precipitation we obtain incremental percentages, which are then converted to inches of precipitation by multiplying each percentage by the total storm precipitation of 2.02 inches.

\section{Cumulative time increments precipitation
(hours) (percent) (hours)

$$
\text { (percent) }
$$ \\ Cumulative \\ (percent)}

0 .25

.50

.75

1.00

1.25

1.50

1.75

2.00

2.25

2.50

2.75

3.00
0

8.33

16.67

25.00

33.33

41.67

50.00

58.33

66.67

75.00

83.33

91.67

100.00

0
5
10
16
31
55
69
75
80
85
90
95
100

5

10

16

31

55

69

75

80

85

90

95

100

\section{Incremental precipitation (percent) (inches)}

\begin{tabular}{rr}
- & - \\
5 & 0.101 \\
5 & .101 \\
6 & .121 \\
15 & .303 \\
24 & .485 \\
14 & .283 \\
6 & .121 \\
5 & .101 \\
5 & .101 \\
5 & .101 \\
5 & .101 \\
5 & .101 \\
\hline 100 & 2.020
\end{tabular}


Rates of Water Loss from Design Storms for Unurbanized Watersheds

The design storms derived in the preceding section cannot be used directly with the unit hydrograph. As explained earlier, a part of the rainfall is unavailable for surface runoff because that part is "lost" in surface retention and infiltration. The time rate of water loss is greatest in the early part of a major storm and rapidly decreases to a rate that becomes nearly constant during the remainder of the storm. Because peak rates of runoff for the San Francisco Bay region generally occur well after the start of a major storm, water loss is assumed to occur at a constant rate during the short-term intense rainfall that is being considered here.

The rates of water loss, $\Phi$, to be used with design storms were determined by a trial-and-error procedure, using peak-discharge data for all watersheds listed in table 2 that are smaller than 100 square miles. (The triangular unit hydrograph is intended for use with small basins, and 100 square miles was arbitrarily chosen as the upper-size limit.) In a preliminary step, a value for base flow--base flow is discussed in the next section of this report--was subtracted from the peak discharges listed in table 2 to obtain peak discharges for the hydrographs of surface runoff. A unit hydrograph was then computed for each of the stations, using the equations of table 6 . The next step was to derive design storms for each watershed for each of the recurrence intervals using the procedure described in the preceding section of this report. Trial values of $\Phi$ (water-loss rate) were then subtracted from the design storms. The resulting values of rainfall excess were used with the appropriate unit hydrographs to obtain hydrographs of surface runoff. Two trials were generally sufficient to provide $\Phi$-values that gave agreement between hydrograph peak and the adjusted peak discharge obtained from either table 2 or from the preceding flood-frequency study.

The $\Phi$-values finally obtained were grouped according to recurrence interval and each group was individually examined. A generalized soils map of the region was first consulted with the expectation of finding a relation between $\Phi$-value and soil type. No such relation was found. However, further examination of the groups of $\Phi$-values revealed that while $\Phi$-values for the 5 -year recurrence interval, $\Phi_{5}$, were grouped randomly about a central value of 0.23 inch per hour, those for the other recurrence intervals varied with the mean annual precipitation for the watersheds used in the study. A separate graph for each recurrence interval was used in plotting watershed $\Phi$-values against the appropriate watershed values of mean annual precipitation. The plotted points scattered widely but a strong trend was clearly evident in each graph, other than that for the 5-year recurrence interval as noted above. A straight line was fitted by eye to each scatter diagram, in such position that half the plotted points were above the line and half were below. The graphs are not shown here but the equations of the lines that were fitted to the plotted points are given below. All values of $\Phi$ are expressed in inches per hour; mean annual precipitation $\left(P_{M A}\right)$ is expressed in inches; the subscript of $\Phi$ refers to recurrence interval, in years. 


$$
\begin{aligned}
& \Phi_{2}=0.500-0.0045 P_{M A} \\
& \Phi_{5}=0.230 \\
& \Phi_{10}=0.185+0.00075 P_{M A} \\
& \Phi_{25}=0.088+0.0024 P_{M A} \\
& \Phi_{50}=0.049+0.0029 P_{M A} \\
& \Phi_{100}=0.0035 P_{M A}
\end{aligned}
$$

For convenience, $\Phi$-values for selected values of mean annual precipitation and recurrence interval are given in table 8 . Values of $\Phi$ for other values of mean annual precipitation and recurrence interval can be obtained by interpolation in the table. As shown in table 8 , the $\Phi$-value for each recurrence interval is assumed to remain constant for values of mean annual precipitation greater than 60 inches.

Examination of the table also shows that $\Phi$-values corresponding to any value of mean annual precipitation decrease as recurrence interval

\begin{tabular}{|c|c|c|c|c|c|c|c|}
\hline \multirow{2}{*}{$\begin{array}{l}\text { Re- } \\
\text { currence } \\
\text { interval } \\
\text { (years) }\end{array}$} & \multicolumn{7}{|c|}{$\begin{array}{l}\Phi \text {-values, in inches per hour, corresponding to } \\
\text { indicated values of mean annual precipitation }\left(\mathrm{P}_{\mathrm{MA}}\right) \text {, } \\
\text { in inches }\end{array}$} \\
\hline & 10 & 20 & 30 & 40 & 50 & 60 & 80 \\
\hline 2 & 0.455 & 0.410 & 0.365 & 0.320 & 0.275 & 0.230 & 0.230 \\
\hline 5 & .230 & .230 & .230 & .230 & .230 & .230 & .230 \\
\hline 10 & .192 & .200 & .208 & .215 & .222 & .230 & .230 \\
\hline 25 & .112 & .136 & .160 & .184 & .208 & .230 & .230 \\
\hline 50 & .078 & .107 & .136 & .165 & .194 & .223 & .223 \\
\hline 100 & .035 & .070 & .105 & .140 & .175 & .210 & .210 \\
\hline
\end{tabular}
increases, and the range of $\Phi$-values over the six recurrence intervals decreases with increase in mean annual precipitation.

TABLE 8.--Design $\Phi-v a l u e s$ for selected values of mean annual precipitation and recurrence interval, for use with unurbanized watersheds 


\section{Base Flow for Design Floods}

It has been mentioned elsewhere that the runoff from the short-term storm bursts we have been considering, is superposed on the base flow already in the channels at the onset of the intense rainfall. Furthermore, the greater flood peaks are invariably associated not only with the more intense storm bursts, but also with the larger values of base flow. It became evident as this study progressed that the magnitude of base flow could be approximated by considering it to equal a percentage of the peak discharge of surface runoff. The percentages assigned for the various recurrence intervals are listed in table 9. They are assumed to be applicable to surface runoff from both urbanized and unurbanized watersheds.

\section{Results of Unit-Hydrograph Computations for Unurbanized Watersheds}

We have now derived all the relations needed to construct discharge hydrographs corresponding to the 2-, 5-, 10-, 25-, 50-, and 100-year floods, for unurbanized watersheds of less than 100 square miles. The mechanics of constructing the hydrographs are illustrated in the sample problem that follows. To get some idea of the reliability of results, the derived relations were used to compute hydrographs for the 34 stations listed in table 2 that have drainage areas of less than 100 square miles. The values of peak discharge so determined were compared with those listed in table 2, and percentage differences were computed. The mean percentage difference for each recurrence interval had a positive bias-that is, it was greater than zero. That bias is attributed to our basing the relations involving $\Phi$ on median values of that parameter rather than on mean values (see p. 36).

\begin{tabular}{c|c}
\hline \multicolumn{3}{|c}{ TABLE 9.--Base flow for design floods } \\
\hline $\begin{array}{c}\text { Recurrence } \\
\text { interval } \\
\text { (years) }\end{array}$ & $\begin{array}{r}\text { Base flow equals peak discharge of surface runoff } \\
\text { times the percentage listed below }\end{array}$ \\
\hline 2 & 5 \\
5 & 5 \\
10 & 10 \\
25 & 15 \\
50 & 20 \\
100 & 25 \\
\hline
\end{tabular}


In table 10 a comparison is made between the results of peakdischarge determinations by flood-frequency analysis and by the unithydrograph method. The percentage figures shown for the flood-frequency method in the third and fourth columns of table 10 were taken from table 3 . The index of error in the last column of table 10 is the algebraic sum of the mean error and the standard deviation of errors about the mean error. Although the values of the index of error obtained for the two methods are not precisely comparable, they provide a valid qualitative comparison. It is seen that the unit-hydrograph method we have designed gave better results overall than did the flood-frequency analysis.

TABLE 10--Comparison of results of peak-discharge determinations for unurbanized watersheds, by floodfrequency analysis and by unit-hydrograph method

\begin{tabular}{|c|c|c|c|c|}
\hline $\begin{array}{c}\text { Recurrence } \\
\text { interva1 } \\
\text { (years) }\end{array}$ & $\begin{array}{l}\text { Method of } \\
\text { analysis }\end{array}$ & $\begin{array}{c}\text { Mean } \\
\text { error } \\
\text { (percent) }\end{array}$ & $\begin{array}{l}\text { Standard } \\
\text { deviation } \\
\text { of errors } \\
\text { about the } \\
\text { mean error } \\
\text { (percent) }\end{array}$ & $\begin{array}{l}\text { Index of error } \\
\text { (percent) }\end{array}$ \\
\hline 2 & $\begin{array}{l}\text { Flood frequency } \\
\text { Unit hydrograph }\end{array}$ & $\begin{array}{c}0 \\
+15.0\end{array}$ & $\begin{array}{l}+68.3 \text { to }-40.5 \\
+45.9 \text { to }-45.9\end{array}$ & $\begin{array}{l}+68.3 \text { to }-40.5 \\
+60.9 \text { to }-30.9\end{array}$ \\
\hline 5 & $\begin{array}{l}\text { Flood frequency } \\
\text { Unit hydrograph }\end{array}$ & $\begin{array}{l}0 \\
+.4\end{array}$ & $\begin{array}{l}+49.6 \text { to }-33.2 \\
+22.4 \text { to }-22.4\end{array}$ & $\begin{array}{l}+49.6 \text { to }-33.2 \\
+22.8 \text { to }-22.0\end{array}$ \\
\hline 10 & $\begin{array}{l}\text { Flood frequency } \\
\text { Unit hydrograph }\end{array}$ & $\begin{array}{c}0 \\
+3.8\end{array}$ & $\begin{array}{l}+47.2 \text { to }-32.1 \\
+27.8 \text { to }-27.8\end{array}$ & $\begin{array}{l}+47.2 \text { to }-32.1 \\
+31.6 \text { to }-24.0\end{array}$ \\
\hline 25 & $\begin{array}{l}\text { Flood frequency } \\
\text { Unit hydrograph }\end{array}$ & $\begin{array}{c}0 \\
+5.2\end{array}$ & $\begin{array}{l}+50.7 \text { to }-33.6 \\
+27.4 \text { to }-27.4\end{array}$ & $\begin{array}{l}+50.7 \text { to }-33.6 \\
+32.6 \text { to }-22.2\end{array}$ \\
\hline 50 & $\begin{array}{l}\text { Flood frequency } \\
\text { Unit hydrograph }\end{array}$ & $\begin{array}{c}0 \\
+11.3\end{array}$ & $\begin{array}{l}+55.6 \text { to }-35.7 \\
+31.9 \text { to }-31.9\end{array}$ & $\begin{array}{l}+55.6 \text { to }-35.7 \\
+43.2 \text { to }-20.6\end{array}$ \\
\hline
\end{tabular}

Sample Problem 3--Unit-Hydrograph Method (Unurbanized Watersheds)

To illustrate the procedure for computing peak discharge for unurbanized watersheds by the unit-hydrograph method, we solve the following hypothetical problem.

Given:

Drainage area $(A)--5.0 \mathrm{sq} \mathrm{mi}$

Mean Annual precipitation--40 inches

Slope index $(S)--225$ feet per mile

Required:

Peak discharge for a 25-year recurrence interval 
Solution:

1. Computation of dimensions of instantaneous unit hydrograph (IUH)

(a) Use equations of table 6

$$
\text { (1) } \begin{aligned}
& \text { Lag }=2.65\left(\mathrm{~A} / \mathrm{S}^{\frac{1}{2}}\right)^{0.199} \\
&=2.65(5.0 / 15.0)^{0.199}=2.13 \text { hours } \\
& \text { (2) } \mathrm{T}_{B_{I}}=6.92\left(\mathrm{~A} / \mathrm{S}^{\frac{1}{2}}\right)^{0.186} \\
&=6.92(5.0 / 15.0)^{0.186}=5.64 \text { hours } \\
& \text { (3) } \mathrm{T}_{P_{I}}=(3 \times \mathrm{Lag})-T_{B_{I}} \\
&=(3 \times 2.13)-5.64=0.75 \text { hour }
\end{aligned}
$$

2. Computation of unit hydrograph (TUH) for unit rainfall of $d$ hours

(a) Value of $d$ should lie within the range of $T_{P} / 5$ and $T_{P} / 3$, where

$$
T_{P}=T_{P_{I}}+d / 2
$$

(b) ${ }^{T} P_{I}$ was computed to be 0.75 hour; use $d=0.25$ hour.

(c) $T_{P}={ }^{T_{P}}{ }_{I}+d / 2=0.75+0.25 / 2=0.875$ hour.

Use $T_{P}=0.75$ hour in order to make the ratio, $T_{P} / d$, an integer equal to 3,4 , or 5 . (A value of 1.00 hour for $T_{P}$ could just as we11 have been used.)

(d) $T_{B}=T_{B_{I}}+d=5.64+0.25=5.89$ hours.

Use $T_{B}=6.00$ hours in order to make the ratio, $T_{B} / d$, an integer. Note that our value of lag remains unchanged by the values of $T_{B}$ and $T_{P}$ that were selected-- $\frac{T_{B}+{ }^{T} P}{3}-d / 2=2.13$--and its value would not have been changed significantly had a value of 1.00 hour been selected for $T_{P}$. 
(e) Peak discharge of $\mathrm{TUH}=\frac{1290.67 \times \text { drainage area }(\mathrm{sq} \mathrm{mi})}{T_{B}}$

$$
=\frac{1290.67 \times 5}{6.00}=1,076 \mathrm{cfs}
$$

(f) We can now construct our TUH by interpolation between the values tabulated below, to obtain discharge ordinates at time intervals of 15 minutes (d).

$\begin{array}{cr}\text { Time (hours) } & \text { Discharge (cfs) } \\ 0.00 & 0 \\ 0.75\left(T_{P}\right) & 1,076 \\ 6.00\left(T_{B}\right) & 0\end{array}$

The unit-hydrograph ordinates are shown in column 2 of table 11.

3. Computation of design storm

(a) For storm duration, $D$, use the next hour larger than the value of lag. Lag equals 2.13 hours; use $D=3$ hours.

(b) Total precipitation for a storm of 3 hours and a recurrence interval of 25 years, occurring in an area having a mean annual precipitation of 40 inches, is obtained from table 4 . Storm precipitation $=2.02$ inches

(c) To obtain the values of storm precipitation at 15-minute intervals for a 3-hour storm totaling 2.02 inches of rain, we go through the steps shown on page 35. The incremental values of storm precipitation are retabulated in columns 1 and 2 of table 12 .

4. Determination of the design rate of water loss ( $\Phi$ )

(a) Water loss, in inches per hour, for a 25-year recurrence interva1, in an area having a mean annual precipitation of 40 inches, is obtained from table 8. $\Phi=0.184$ inch per hour, or 0.046 inch per 15 minutes.

5. Computation of precipitation excess for time intervals (d) of 15 minutes.

(a) Subtract 0.046 inch from each value of precipitation in column 2 of table 12, and enter results in column 4 of table 12. Transfer values of precipitation excess to the top row of table 11.

6. Computation of the hydrograph of surface runoff

(a) The hydrograph of surface runoff is computed as shown in table 11. Multiply the first value of precipitation excess (top value in column 3) by each ordinate of the unit hydrograph--the ordinates are listed in column 2. Tabulate the products in column 3. Then multiply the next value of precipitation excess (top value in column 4) by each ordinate of the unit hydrograph, but lag the products by one time unit before recording them in column 4 . Continue this procedure until all values of precipitation excess have been used.

(b) Add all products horizontally to obtain the design hydrograph of surface runoff. Tabulate the sums in column 15 of table 11. 
TABLE 11.--Computation of design discharge hydrograph--sample problem 3

\begin{tabular}{|c|c|c|c|c|c|c|c|c|c|c|c|c|c|c|c|c|}
\hline \multirow[b]{2}{*}{$\begin{array}{c}\begin{array}{c}\text { Time } \\
\text { (hours) }\end{array} \\
(1)\end{array}$} & \multirow[b]{2}{*}{$\begin{array}{c}\text { TUH } \\
(\mathrm{cfs}) \\
(2)\end{array}$} & \multicolumn{12}{|c|}{ Precipitation excess, in inches } & \multirow[b]{2}{*}{\begin{tabular}{|}
$\begin{array}{l}\text { Surface } \\
\text { runoff } \\
(\text { cfs })\end{array}$ \\
$(15)$
\end{tabular}} & \multirow[b]{2}{*}{$\begin{array}{l}\text { Base } \\
\text { flow } \\
(\mathrm{cfs}) \\
(16)\end{array}$} & \multirow[b]{2}{*}{$\begin{array}{l}\text { Total } \\
\text { runoff } \\
\text { (cfs) } \\
(17)\end{array}$} \\
\hline & & $\begin{array}{c}0.055 \\
(3)\end{array}$ & $\begin{array}{c}0.055 \\
(4) \\
\end{array}$ & $\begin{array}{c}0.075 \\
(5)\end{array}$ & $\begin{array}{c}0.257 \\
(6)\end{array}$ & $\begin{array}{c}0.439 \\
(7)\end{array}$ & $\begin{array}{c}0.237 \\
(8)\end{array}$ & $\begin{array}{c}0.075 \\
(9)\end{array}$ & $\begin{array}{r}0.055 \\
(10)\end{array}$ & $\begin{array}{r}0.055 \\
(11)\end{array}$ & $\begin{array}{r}0.055 \\
(12)\end{array}$ & $\begin{array}{r}0.055 \\
(13)\end{array}$ & $\begin{array}{l}0.055 \\
(14)\end{array}$ & & & \\
\hline $\begin{array}{l}0.00 \\
.25 \\
.50 \\
.75\end{array}$ & $\begin{array}{r}0 \\
359 \\
717 \\
1076\end{array}$ & $\begin{array}{c}0 \\
19.7 \\
39.4 \\
59.2\end{array}$ & $\begin{array}{c}0 \\
19.7 \\
39.4\end{array}$ & $\begin{array}{c}0 \\
26.9\end{array}$ & 0 & & & & & & & & & $\begin{array}{r}0 \\
19.7 \\
59.1 \\
125.5\end{array}$ & $\begin{array}{l}180 \\
180 \\
180 \\
180\end{array}$ & $\begin{array}{l}180 \\
200 \\
239 \\
306\end{array}$ \\
\hline $\begin{array}{l}1.00 \\
1.25 \\
1.50 \\
1.75\end{array}$ & $\begin{array}{r}1025 \\
974 \\
922 \\
871\end{array}$ & $\begin{array}{l}56.4 \\
53.6 \\
50.7 \\
47.9\end{array}$ & $\begin{array}{l}59.2 \\
56.4 \\
53.6 \\
50.7\end{array}$ & $\begin{array}{l}53.8 \\
80.7 \\
76.9 \\
73.0\end{array}$ & $\begin{array}{r}92.2 \\
184.3 \\
276.5 \\
263.4\end{array}$ & $\begin{array}{c}0 \\
157.6 \\
314.8 \\
472.4\end{array}$ & $\begin{array}{c}0 \\
85.1 \\
169.9\end{array}$ & $\begin{array}{c}0 \\
26.9\end{array}$ & 0 & & & & & $\begin{array}{r}261.6 \\
532.6 \\
857.6 \\
1104.2\end{array}$ & $\begin{array}{l}180 \\
180 \\
180 \\
180\end{array}$ & $\begin{array}{r}442 \\
713 \\
1038 \\
1284\end{array}$ \\
\hline $\begin{array}{l}2.00 \\
2.25 \\
2.50 \\
2.75\end{array}$ & $\begin{array}{l}820 \\
769 \\
717 \\
666\end{array}$ & $\begin{array}{l}45.1 \\
42.3 \\
39.4 \\
36.6\end{array}$ & $\begin{array}{l}47.9 \\
45.1 \\
42.3 \\
39.4\end{array}$ & $\begin{array}{l}69.2 \\
65.3 \\
61.5 \\
57.7\end{array}$ & $\begin{array}{l}250.3 \\
237.0 \\
223.8 \\
210.7\end{array}$ & $\begin{array}{l}450.0 \\
427.6 \\
404.8 \\
382.4\end{array}$ & $\begin{array}{l}255.0 \\
242.9 \\
230.8 \\
218.5\end{array}$ & $\begin{array}{l}53.8 \\
80.7 \\
76.9 \\
73.0\end{array}$ & $\begin{array}{l}19.7 \\
39.4 \\
59.2 \\
56.4\end{array}$ & $\begin{array}{c}0 \\
19.7 \\
39.4 \\
59.2\end{array}$ & $\begin{array}{c}0 \\
19.7 \\
39.4\end{array}$ & $\begin{array}{c}0 \\
19.7\end{array}$ & 0 & $\begin{array}{l}1191.0 \\
1200.0 \\
1197.8 \\
1193.0\end{array}$ & $\begin{array}{l}180 \\
180 \\
180 \\
180\end{array}$ & $\begin{array}{l}1371 \\
1380 \\
1378 \\
1373\end{array}$ \\
\hline $\begin{array}{l}3.00 \\
3.25 \\
3.50 \\
3.75\end{array}$ & $\begin{array}{l}615 \\
564 \\
512 \\
461\end{array}$ & $\begin{array}{l}33.8 \\
31.0 \\
28.2 \\
25.4\end{array}$ & $\begin{array}{l}36.6 \\
33.8 \\
31.0 \\
28.2\end{array}$ & $\begin{array}{l}53.8 \\
50.0 \\
46.2 \\
42.3\end{array}$ & $\begin{array}{l}197.6 \\
184.3 \\
171.2 \\
158.1\end{array}$ & $\begin{array}{l}360.0 \\
337.6 \\
314.8 \\
292.4\end{array}$ & $\begin{array}{l}206.4 \\
194.3 \\
182.3 \\
169.9\end{array}$ & $\begin{array}{l}69.2 \\
65.3 \\
61.5 \\
57.7\end{array}$ & $\begin{array}{l}53.6 \\
50.7 \\
47.9 \\
45.1\end{array}$ & $\begin{array}{l}56.4 \\
53.6 \\
50.7 \\
47.9\end{array}$ & $\begin{array}{l}59.2 \\
56.4 \\
53.6 \\
50.7\end{array}$ & $\begin{array}{l}39.4 \\
59.2 \\
56.4 \\
53.6\end{array}$ & $\begin{array}{l}19.7 \\
39.4 \\
59.2 \\
56.4\end{array}$ & $\begin{array}{l}1185.7 \\
1155.6 \\
1103.0 \\
1027.7\end{array}$ & $\begin{array}{l}180 \\
180 \\
180 \\
180\end{array}$ & $\begin{array}{l}1366 \\
1336 \\
1283 \\
1208\end{array}$ \\
\hline $\begin{array}{l}4.00 \\
4.25 \\
4.50 \\
4.75\end{array}$ & $\begin{array}{l}410 \\
359 \\
307 \\
256\end{array}$ & $\begin{array}{l}22.6 \\
19.7 \\
16.9 \\
14.1\end{array}$ & $\begin{array}{l}25.4 \\
22.6 \\
19.7 \\
16.9\end{array}$ & $\begin{array}{l}38.4 \\
34.6 \\
30.8 \\
26.9\end{array}$ & $\begin{array}{l}144.9 \\
131.6 \\
118.5 \\
105.4\end{array}$ & $\begin{array}{l}270.0 \\
247.6 \\
224.8 \\
202.4\end{array}$ & $\begin{array}{l}157.8 \\
145.8 \\
133.7 \\
121.3\end{array}$ & $\begin{array}{l}53.8 \\
50.0 \\
46.2 \\
42.3\end{array}$ & $\begin{array}{l}42.3 \\
39.4 \\
36.6 \\
33.8\end{array}$ & $\begin{array}{l}45.1 \\
42.3 \\
39.4 \\
36.6\end{array}$ & $\begin{array}{l}47.9 \\
45.1 \\
42.3 \\
39.4\end{array}$ & $\begin{array}{l}50.7 \\
47.9 \\
45.1 \\
42.3\end{array}$ & $\begin{array}{l}53.6 \\
50.7 \\
47.9 \\
45.1\end{array}$ & $\begin{array}{l}952.5 \\
877.3 \\
801.9 \\
726.5\end{array}$ & $\begin{array}{l}180 \\
180 \\
180 \\
180\end{array}$ & $\begin{array}{r}1132 \\
1057 \\
982 \\
906\end{array}$ \\
\hline $\begin{array}{l}5.00 \\
5.25 \\
5.50 \\
5.75\end{array}$ & $\begin{array}{r}205 \\
154 \\
102 \\
51\end{array}$ & $\begin{array}{r}11.3 \\
8.5 \\
5.6 \\
2.8\end{array}$ & $\begin{array}{r}14.1 \\
11.3 \\
8.5 \\
5.6\end{array}$ & $\begin{array}{l}23.0 \\
19.2 \\
15.4 \\
11.6\end{array}$ & $\begin{array}{l}92.3 \\
78.9 \\
65.8 \\
52.7\end{array}$ & $\begin{array}{l}180.0 \\
157.6 \\
134.8 \\
112.4\end{array}$ & $\begin{array}{r}109.3 \\
97.2 \\
85.1 \\
72.8\end{array}$ & $\begin{array}{l}38.4 \\
34.6 \\
30.8 \\
26.9\end{array}$ & $\begin{array}{l}31.0 \\
28.2 \\
25.4 \\
22.6\end{array}$ & $\begin{array}{l}33.8 \\
31.0 \\
28.2 \\
25.4\end{array}$ & $\begin{array}{l}36.6 \\
33.8 \\
31.0 \\
28.2\end{array}$ & $\begin{array}{l}39.4 \\
36.6 \\
33.8 \\
31.0\end{array}$ & $\begin{array}{l}42.3 \\
39.4 \\
36.6 \\
33.8\end{array}$ & $\begin{array}{l}651.5 \\
576.3 \\
501.0 \\
425.8\end{array}$ & $\begin{array}{l}180 \\
180 \\
180 \\
180\end{array}$ & $\begin{array}{l}832 \\
756 \\
681 \\
606\end{array}$ \\
\hline $\begin{array}{l}6.00 \\
6.25 \\
6.50 \\
6.75\end{array}$ & 0 & 0 & $\begin{array}{l}2.8 \\
0\end{array}$ & $\begin{array}{l}7.6 \\
3.8 \\
0\end{array}$ & $\begin{array}{c}39.6 \\
26.2 \\
13.1 \\
0\end{array}$ & $\begin{array}{l}90.0 \\
67.6 \\
44.8 \\
22.4\end{array}$ & $\begin{array}{l}60.7 \\
48.6 \\
36.5 \\
24.2\end{array}$ & $\begin{array}{l}23.0 \\
19.2 \\
15.4 \\
11.6\end{array}$ & $\begin{array}{l}19.7 \\
16.9 \\
14.1 \\
11.3^{\circ}\end{array}$ & $\begin{array}{l}22.6 \\
19.7 \\
16.9 \\
14.1\end{array}$ & $\begin{array}{l}25.4 \\
22.6 \\
19.7 \\
16.9\end{array}$ & $\begin{array}{l}28.2 \\
25.4 \\
22.6 \\
19.7\end{array}$ & $\begin{array}{l}31.0 \\
28.2 \\
25.4 \\
22.6\end{array}$ & $\begin{array}{l}350.6 \\
278.2 \\
208.5 \\
142.8\end{array}$ & $\begin{array}{l}180 \\
180 \\
180 \\
180\end{array}$ & $\begin{array}{l}531 \\
458 \\
388 \\
323\end{array}$ \\
\hline $\begin{array}{l}7.00 \\
7.25 \\
7.50 \\
7.75\end{array}$ & & & & & & 0 & $\begin{array}{c}12.1 \\
0\end{array}$ & $\begin{array}{l}7.6 \\
3.8 \\
0\end{array}$ & $\begin{array}{l}8.5 \\
5.6 \\
2.8 \\
0\end{array}$ & $\begin{array}{r}11.3 \\
8.5 \\
5.6 \\
2.8\end{array}$ & $\begin{array}{r}14.1 \\
11.3 \\
8.5 \\
5.6\end{array}$ & $\begin{array}{r}16.9 \\
14.1 \\
11.3 \\
8.5\end{array}$ & $\begin{array}{l}19.7 \\
16.9 \\
14.1 \\
11.3\end{array}$ & $\begin{array}{l}90.2 \\
60.2 \\
42.3 \\
28.2\end{array}$ & $\begin{array}{l}180 \\
180 \\
180 \\
180\end{array}$ & $\begin{array}{l}270 \\
240 \\
222 \\
208\end{array}$ \\
\hline $\begin{array}{l}8.00 \\
8.25 \\
8.50 \\
8.75\end{array}$ & & & & & & & & & & 0 & $\begin{array}{l}2.8 \\
0\end{array}$ & $\begin{array}{l}5.6 \\
2.8 \\
0\end{array}$ & $\begin{array}{l}8.5 \\
5.6 \\
2.8 \\
0\end{array}$ & $\begin{array}{r}16.9 \\
8.4 \\
2.8 \\
0\end{array}$ & $\begin{array}{l}180 \\
180 \\
180 \\
180\end{array}$ & $\begin{array}{l}197 \\
188 \\
183 \\
180\end{array}$ \\
\hline
\end{tabular}


TABLE 12.--Computation of design precipitation excess-sample problem 3

\begin{tabular}{c|c|c|c}
\hline $\begin{array}{c}\text { Time } \\
\text { (hours) }\end{array}$ & $\begin{array}{c}\text { Precipitation for } \\
\text { period ending at } \\
\text { time indicated in } \\
\text { column 1 (inches) }\end{array}$ & $\begin{array}{c}\text { Water loss } \\
\text { (inches per } \\
\text { 15 minutes) }\end{array}$ & $\begin{array}{c}\text { Precipitation excess } \\
\text { (inches) }\end{array}$ \\
\hline 0 & - & - & - \\
.25 & 0.101 & 0.046 & 0.055 \\
.50 & .101 & .046 & .055 \\
.75 & .121 & .046 & .075 \\
1.00 & .303 & .046 & .257 \\
1.25 & .485 & .046 & .439 \\
1.50 & .283 & .046 & .237 \\
1.75 & .121 & .046 & .075 \\
2.00 & .101 & .046 & .055 \\
2.25 & .101 & .046 & .055 \\
2.50 & .101 & .046 & .055 \\
2.75 & .101 & .046 & .055 \\
3.00 & .101 & .046 & .055 \\
Tota1 & 2.020 & .552 & 1.468 \\
\hline
\end{tabular}

7. Determination of base flow

(a) The design value of base flow is obtained from table 9. For a recurrence interval of 25 -years, table 9 shows base flow to equal 15 percent of the peak discharge of surface runoff. The peak value in column 15 of table 11 is $1,200 \mathrm{cfs}$; therefore base flow equals $0.15 \times 1,200$ or $180 \mathrm{cfs}$.

8. Computation of the hydrograph of total runoff

(a) Add the value of base flow, $180 \mathrm{cfs}$, to each ordinate of the hydrograph of surface runoff, as given in column 15 of table 11. The peak discharge of the hydrograph of total runoff becomes 1,380 cfs.

9. Discussion of results: It is interesting to compare the results obtained in the sample problem above with those obtained in sample problem 1, which was computed by the flood-frequency method. The same basic data were used in both problems, the only difference being that the unit-hydrograph method considers basin slope, whereas that parameter is not used in the flood-frequency analysis. However, slope affects only the dimensions of the unit-hydrograph, and the nature of the relations derived in the unit-hydrograph study is such that slope is a significant, but not critical, factor. For an unurbanized basin of 5 square miles, having a mean annual precipitation of 40 inches, the flood-frequency method gave a 25 -year flood peak of $1,390 \mathrm{cfs}$; the unit-hydrograph method gave 1,380 cfs. 
To continue the comparison of results by the two methods, complete flood-frequency curves were prepared for the hypothetical

5-square-mile area, assuming first that the mean annual precipitation was 20 inches, then 40 inches, and finally 60 inches. The three curves, as computed by the flood-frequency method, are shown in figure 9. Peak discharges for six recurrence intervals, computed by the unit-hydrograph method, are plotted on figure 9 for comparison. The agreement is surprisingly close.

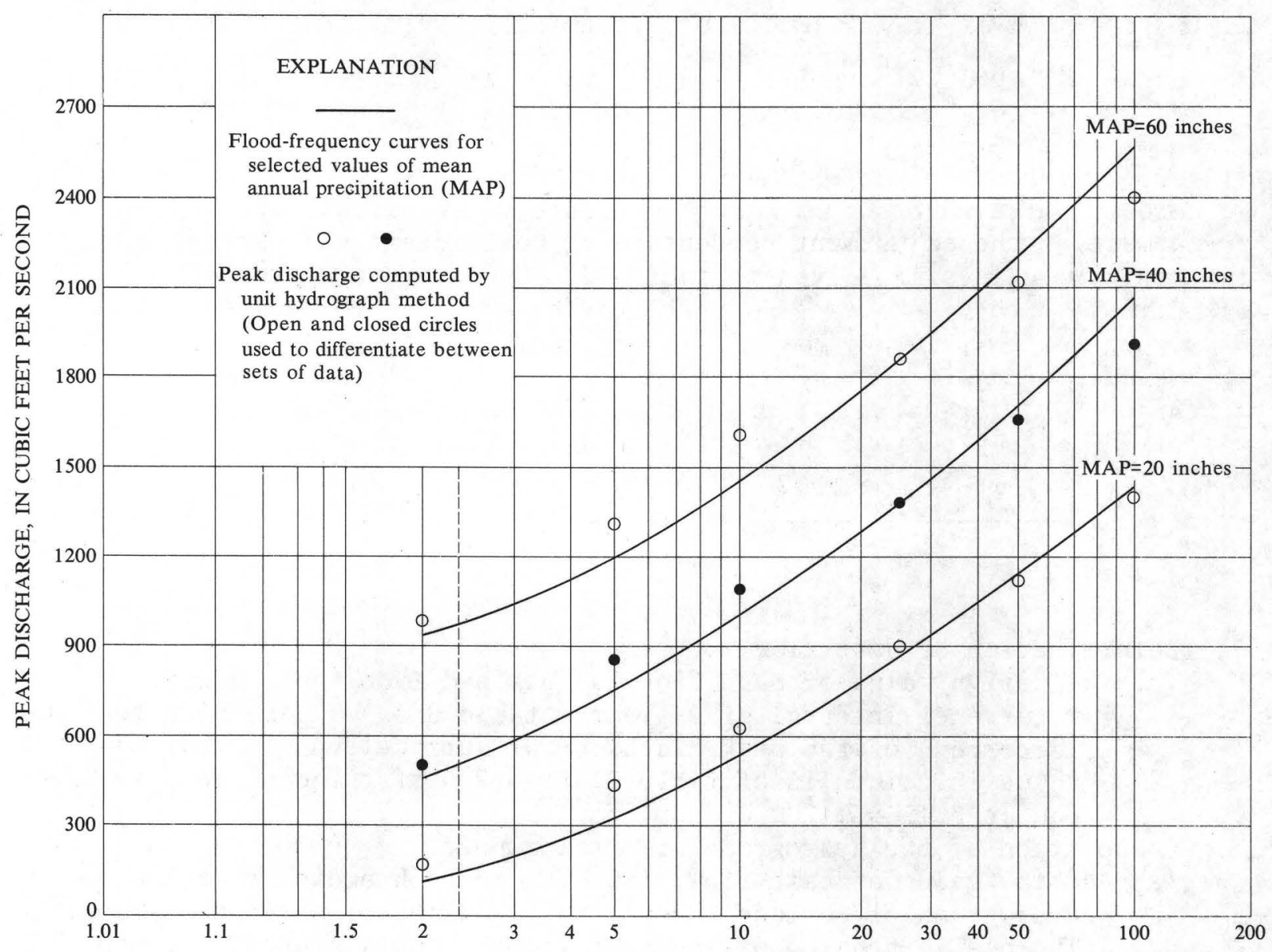

RECURRENCE INTERVAL, IN YEARS

FIGURE 9.--Comparison of design discharges for unurbanized watersheds computed by flood-frequency and unit-hydrograph methods. 
Synthetic Unit Hydrographs for Urbanized Watersheds

As mentioned earlier, data are not available for evaluating the effect of urbanization on storm discharge in the San Francisco Bay region. However, almost all studies in other parts of the Nation have shown basin 1 ag for completely urbanized watersheds to be from 10 to 50 percent of that for rural or unurbanized watersheds. For this study it was assumed that for a completely urbanized watershed, 1 ag was 25 percent of that for the watershed in its natural state. The time base of the instantaneous unit hydrograph $\left.\mid T_{B_{I}}\right)$ and the time-to-peak $\left|T_{P_{I}}\right|$ were also assumed to be 25 percent of their values for a watershed in its natural state.

For partly urbanized watersheds the adjustment percentage was linearly interpolated between 100 percent for a rural watershed and 25 percent for a watershed that was completely urbanized. No further refinement of the adjustment percentage or coefficient was warranted. Interpolated values are given in table 13. Once the characteristic dimensions of the instantaneous unit hydrograph (IUH) for an urbanized or partly urbanized watershed are computed, the dimensions of the unit hydrograph for a finite time interval, $d$, are obtained in the manner described for unurbanized watersheds. The value of $d$ selected is one that is between $1 / 5$ and $1 / 3$ of the value of $T_{p}$.

TABLE 13.--Coefficients to convert time dimensions-rag, $\mathrm{T}_{\mathrm{B}_{\mathrm{I}}}$, and $\mathrm{T}_{\mathrm{P}_{\mathrm{I}}}$-of the IUH for an unurbanized watershed to those of the IUH for an urbanized or partly urbanized watershed

\begin{tabular}{ccc}
\hline $\begin{array}{c}\text { Degree of urbanization } \\
\text { (percentage of total watershed) }\end{array}$ & Coefficient \\
\hline 0 (unurbanized) & 1.00 \\
10 & .92 \\
20 & .85 \\
30 & .78 \\
40 & .70 \\
50 & .62 \\
60 & .55 \\
70 & .48 \\
80 & .40 \\
90 & .32 \\
100 & .25 \\
\hline
\end{tabular}


Design Storms and Rates of Water Loss for Urbanized Watersheds

The degree of urbanization of a watershed has no effect on the method of selecting a design storm. Therefore the procedure used to determine the design storm is that described in the section of this report that deals with urbanized watersheds. Storm duration, $D$, equals the next hour larger than the lag computed for the urbanized watershed; table 4 gives the total storm precipitation for the selected value of $D$ and the desired recurrence interval; table 7 provides the percentages needed to distribute the total storm precipitation by time increments equal to $d$.

There were no data to provide a basis for determining rates of water loss for urbanized or partly urbanized basins. The method finally selected for making that determination was based on the following rationale:

1. A11 water loss occurs on the permeable areas of the watershed.

2. On the basis of table 1 , only half the urbanized area is made impervious.

3. Therefore the permeable area, expressed as a percentage of the total watershed area, equals 100 percent minus $1 / 2$ (percentage of watershed that is urbanized).

The percentages expressed as decimal coefficients, are computed and tabulated in table 14 for various degrees of urbanization. For obtaining design water losses, those coefficients are applied to the $\Phi$-values that are given in table 8 for unurbanized watersheds.

TABLE 14.--Coefficients to convert $\Phi$-values for an unurbanized watershed to those for an urbanized or partly urbanized watershed

\begin{tabular}{c|c|c}
\hline $\begin{array}{c}\text { Degree of urbanization } \\
\text { (percentage of total } \\
\text { watershed) }\end{array}$ & $\begin{array}{c}0.5 \text { times } \\
\text { decimal values } \\
\text { in column 1 }\end{array}$ & $\begin{array}{c}\text { Coefficient } \\
\text { (equals 1.00 minus } \\
\text { values in column 2) }\end{array}$ \\
\hline 0 (unurbanized) & 0 & 1.00 \\
10 & .05 & .95 \\
20 & .10 & .90 \\
30 & .15 & .85 \\
40 & .20 & .80 \\
50 & .25 & .75 \\
60 & .30 & .70 \\
70 & .35 & .65 \\
80 & .40 & .60 \\
90 & .45 & .55 \\
100 & .50 & .50 \\
\hline
\end{tabular}


Sample Problem 4--Unit-Hydrograph Method (Urbanized Watersheds)

To illustrate the procedure for computing peak discharge for urbanized watersheds by the unit-hydrograph method, we solve the following hypothetical problem. (Aside from the urbanization feature, the characteristics of our watershed and the peak discharge sought are those used in sample problem 3.)

Given:

Drainage area $(A)--5.0 \mathrm{sq} \mathrm{mi}$

Mean annual precipitation--40 inches

Slope index $(S)--225$ feet per mile

Degree of development--Residential development on 70 percent of the watershed; the remaining 30 percent in natural condition.

Required:

Peak discharge for a 25-year recurrence interval

Solution:

1. Computation of dimensions of instantaneous unit hydrograph (IUH)

(a) Use equations of table 6 , as in step 1 of sample problem 3, to obtain lag, $T_{B_{I}}$, and $T_{P_{I}}$ for an unurbanized basin. From sample problem 3, these values are $2.13,5.64$, and 0.75 hours, respectively.

(b) From table 13 obtain the coefficient, 0.48 , to convert the above time dimensions to those for a watershed that is 70 percent urbanized.

$$
\begin{aligned}
& \text { Lag }=0.48 \times 2.13=1.02 \text { hours } \\
& { }^{T_{B}}=0.48 \times 5.64=2.71 \text { hours } \\
& { }_{T_{I}}=0.48 \times 0.75=0.36 \text { hour }
\end{aligned}
$$

2. Compute unit hydrograph (TUH) for unit rainfa11 of $d$ hours

(a) Value of $d$ should lie within the range of $T_{P} / 5$ and $T_{P} / 3$, where

$$
T_{P}=T_{P_{I}}+d / 2
$$

(b) ${ }^{T} P_{I}$ was computed to be 0.36 hour; use $d=0.083$ hour, or 5 minutes

(c) ${ }^{T}{ }_{P}=T_{P_{I}}+d / 2=0.36+0.04=0.40$ hour

Use $T_{P}=0.42$ hour (25 minutes) in order to make the ratio, $T_{P} / d$, an integer equal to 3,4 , or 5 . 
(d) $T_{B}=T_{B_{I}}+d=2.71+.08=2.79$ hours

Use $T_{B}=2.75$ hours in order to make the ratio, $T_{B} / d$, an integer.

(e) Peak discharge of $\mathrm{TUH}=\frac{1290.67 \times \text { drainage area }(\mathrm{sq} \mathrm{mi})}{T_{B}}$

$$
=\frac{1290.67 \times 5}{2.75}=2,347 \mathrm{cfs}
$$

(f) We can now construct our TUH by interpolation between the values tabulated below, to obtain discharge ordinates at time intervals of 5 minutes (d)

$\begin{array}{cr}\text { Time (minutes) } & \text { Discharge (cfs) } \\ 25(0.42 \mathrm{hr}) & 0 \\ 165(2.75 \mathrm{hr}) & 0\end{array}$

The unit hydrograph ordinates and corresponding time ordinates are shown in table 15 .

TABLE 15.--Ordinates of 5-minute triangular unit hydrograph--sample problem 4

\begin{tabular}{cc|cc}
\hline $\begin{array}{c}\text { Time } \\
\text { (minutes) }\end{array}$ & $\begin{array}{c}\text { Discharge } \\
\text { (cfs) }\end{array}$ & $\begin{array}{c}\text { Time } \\
\text { (minutes) }\end{array}$ & $\begin{array}{c}\text { Discharge } \\
\text { (cfs) }\end{array}$ \\
\hline 0 & 0 & 85 & 1,341 \\
5 & 469 & 90 & 1,257 \\
10 & 939 & 95 & 1,173 \\
15 & 1,408 & 100 & 1,090 \\
20 & 1,878 & 105 & 1,006 \\
25 & 2,347 & 110 & 922 \\
30 & 2,263 & 115 & 838 \\
35 & 2,179 & 120 & 754 \\
40 & 2,096 & 125 & 671 \\
45 & 2,012 & 130 & 587 \\
50 & 1,928 & 135 & 503 \\
55 & 1,844 & 140 & 419 \\
60 & 1,760 & 145 & 335 \\
65 & 1,676 & 150 & 251 \\
70 & 1,593 & 155 & 168 \\
75 & 1,509 & 160 & 84 \\
80 & 1,425 & 165 & 0 \\
\hline & & &
\end{tabular}


3. Computation of design storm

(a) For storm duration, $D$, use next hour larger than the value of $1 \mathrm{ag}$. Lag $=1.02$ hours; use $D=2$ hours

(b) Total precipitation for a storm of 2 hours and a recurrence interval of 25 years, occurring in an area having a mean annual precipitation of 40 inches, is obtained from table 4 . Storm precipitation $=1.56$ inches

(c) To obtain the values of storm precipitation at 5-minute intervals we use table 7 , and perform the computations detailed in table 16.

TABLE 16.--Computation of storm precipitation in increments of 5 minutes--sample problem 4

\begin{tabular}{|c|c|c|c|c|}
\hline \multicolumn{2}{|c|}{ Cumulative time increments } & \multirow{2}{*}{$\begin{array}{l}\text { Cumulative } \\
\text { precipitation } \\
\text { (percent) }\end{array}$} & \multicolumn{2}{|c|}{$\begin{array}{c}\text { Incremental } \\
\text { precipitation }\end{array}$} \\
\hline Minutes & Percent & & Percent & Inches \\
\hline 0 & 0 & 0 & - & - \\
\hline 5 & 4.17 & 2 & 2 & 0.031 \\
\hline 10 & 8.33 & 4 & 2 & .031 \\
\hline 15 & 12.50 & 6 & 2 & .031 \\
\hline 20 & 16.67 & 8 & 2 & .031 \\
\hline 25 & 20.83 & 11 & 3 & .047 \\
\hline 30 & 25.00 & 14 & 3 & .047 \\
\hline 35 & 29.17 & 19 & 5 & .078 \\
\hline 40 & 33.33 & 29 & 10 & .156 \\
\hline 45 & 37.50 & 42 & 13 & .203 \\
\hline 50 & 41.67 & 55 & 13 & .203 \\
\hline 55 & 45.83 & 63 & 8 & .125 \\
\hline 60 & 50.00 & 70 & 7 & .109 \\
\hline 65 & 54.17 & 74 & 4 & .062 \\
\hline 70 & 58.33 & 78 & 4 & .062 \\
\hline 75 & 62.50 & 81 & 3 & .047 \\
\hline 80 & 66.67 & 84 & 3 & .047 \\
\hline 85 & 70.83 & 87 & 3 & .047 \\
\hline 90 & 75.00 & 90 & 3 & .047 \\
\hline 95 & 79.17 & 92 & 2 & .031 \\
\hline 100 & 83.33 & 94 & 2 & .031 \\
\hline 105 & 87.50 & 96 & 2 & .031 \\
\hline 110 & 91.67 & 98 & 2 & .031 \\
\hline 115 & 95.83 & 99 & 1 & .016 \\
\hline 120 & 100.00 & 100 & 1 & .016 \\
\hline Tota1 & & & 100 & 1.560 \\
\hline
\end{tabular}


4. Determination of the design rate of water loss, $\Phi$

(a) Water loss, in inches per hour, for a 25-year recurrence interval, in an unurbanized area having a mean annual precipitation of 40 inches, is obtained from table 8. That value is 0.184 inch per hour. The adjustment coefficient for 70 percent urbanization is found in table 14 to be $0.65 . \Phi$ is therefore equal to $0.65 \times 0.184--0.120$ inch per hour, or 0.010 inch per 5 minutes.

5. Computation of precipitation excess for time intervals (d) of 5 minutes

(a) Subtract 0.010 inch from each value of incremental precipitation in table 16 and tabulate the values obtained. (Tabulation not shown here.)

6. Computation of the hydrograph of surface runoff

(a) The detailed computation of the hydrograph of surface runoff is not shown here, but is similar to that shown in table 11. The ordinates of the unit hydrograph in table 15 are applied to the increments of precipitation excess obtained in step 5 above. The resulting ordinates of the hydrograph of surface runoff are given in table 17.

TABLE 17.--Ordinates of design hydrograph of surface runoff--sample problem 4

\begin{tabular}{ccccccc}
\hline $\begin{array}{c}\text { Time } \\
\text { (minutes) }\end{array}$ & $\begin{array}{c}\text { Discharge } \\
\text { (cfs) }\end{array}$ & $\begin{array}{c}\text { Time } \\
\text { (minutes) }\end{array}$ & $\begin{array}{c}\text { Discharge } \\
\text { (cfs) }\end{array}$ & $\begin{array}{c}\text { Time } \\
\text { (minutes) }\end{array}$ & $\begin{array}{c}\text { Discharge } \\
\text { (cfs) }\end{array}$ \\
\hline 0 & 0 & 95 & 2246 & 190 & 557 \\
5 & 10 & 100 & 2224 & 195 & 459 \\
10 & 30 & 105 & 2192 & 200 & 368 \\
15 & 59 & 110 & 2149 & 205 & 288 \\
20 & 99 & 115 & 2089 & 210 & 225 \\
25 & 155 & 120 & 2020 & 215 & 178 \\
30 & 218 & 125 & 1939 & 220 & 140 \\
35 & 301 & 130 & 1847 & 225 & 111 \\
40 & 440 & 135 & 1743 & 230 & 86 \\
45 & 659 & 140 & 1635 & 235 & 66 \\
50 & 948 & 145 & 1525 & 240 & 49 \\
55 & 1270 & 150 & 1414 & 245 & 34 \\
60 & 1602 & 155 & 1303 & 250 & 23 \\
65 & 1877 & 160 & 1193 & 255 & 15 \\
70 & 2069 & 165 & 1082 & 260 & 9 \\
75 & 2172 & 170 & 973 & 265 & 4 \\
80 & 2229 & 175 & 866 & 270 & 2 \\
85 & 2249 & 180 & 761 & 275 & 1 \\
90 & 2257 & 185 & 657 & 280 & 0 \\
\hline
\end{tabular}


7. Determination of base flow

(a) The design value of base flow is obtained from table 9. For a recurrence interval of 25-years, table 9 shows base flow to equal 15 percent of the peak discharge of surface runoff. The peak value in table 17 is 2,257 cfs; therefore base flow equals $0.15 \times 2,257 \mathrm{cfs}$ or $340 \mathrm{cfs}$.

8. Computation of the hydrograph of total runoff

(a) Add the value of base flow, $340 \mathrm{cfs}$, to each ordinate of the hydrograph of surface runoff, as given in table 17. (The addition is not shown here.) The peak discharge of the hydrograph of total runoff becomes 2,600 cfs.

9. Discussion of results: It is interesting to compare the results obtained in the sample problem above with those obtained in sample problem 1, which was computed by the flood-frequency method. The same basic data were used in both problems, the only difference being that basin slope, used as a parameter in the unit-hydrograph method, was not used in the flood-frequency method. For the basin of 5 square miles, that is 70 percent urbanized and has a mean annual precipitation of 40 inches, the flood-frequency method gave a 25 -year flood peak of 2,640 cfs; the unit-hydrograph method gave 2,600 cfs.

It was noted earlier (p. 44) that for unurbanized watersheds the two methods gave peak discharges that were in fairly close agreement. We now compare the adjustments for the effect of urbanization indicated by the two methods. If we assume that in all basins the percentage of watershed urbanized equals the percentage of channels sewered or lined, the six families of curves in figure 3 , that were used in the flood-frequency method, can be represented by a single adjustment curve for each of the six recurrence intervals. The adjustment curves so obtained are presented in. figures 10-12. Next we took the hypothetical watershed whose area and basin slope are given in sample problem 4, and by applying the unithydrograph method, computed peak discharges for the six recurrence intervals and for five different degrees of urbanization, ranging from 0 to 100 percent. That was done first assuming a mean annual precipitation of 20 inches, then 40 inches, and finally 60 inches. Then using the peak discharge for 0 percent urbanization as a base for each set of peak discharges, we computed the adjustment coefficients that would be required to convert the base discharges to the urban discharges obtained by the unit-hydrograph method. The computed adjustment coefficients, which are actually the ratios of flood-peak magnitude for urbanized watersheds to that for unurbanized watersheds, are also plotted in figures 10-12.

Inspection of figures 10-12 shows that the coefficients computed by the unit-hydrograph method vary inversely with both recurrence interval and mean annual precipitation. Mean annual precipitation, however, has a lesser effect at the larger recurrence intervals. The coefficients used with the flood-frequency method vary only with recurrence interval. The agreement between the coefficients or ratios used in the two methods is closest at the large recurrence intervals. 


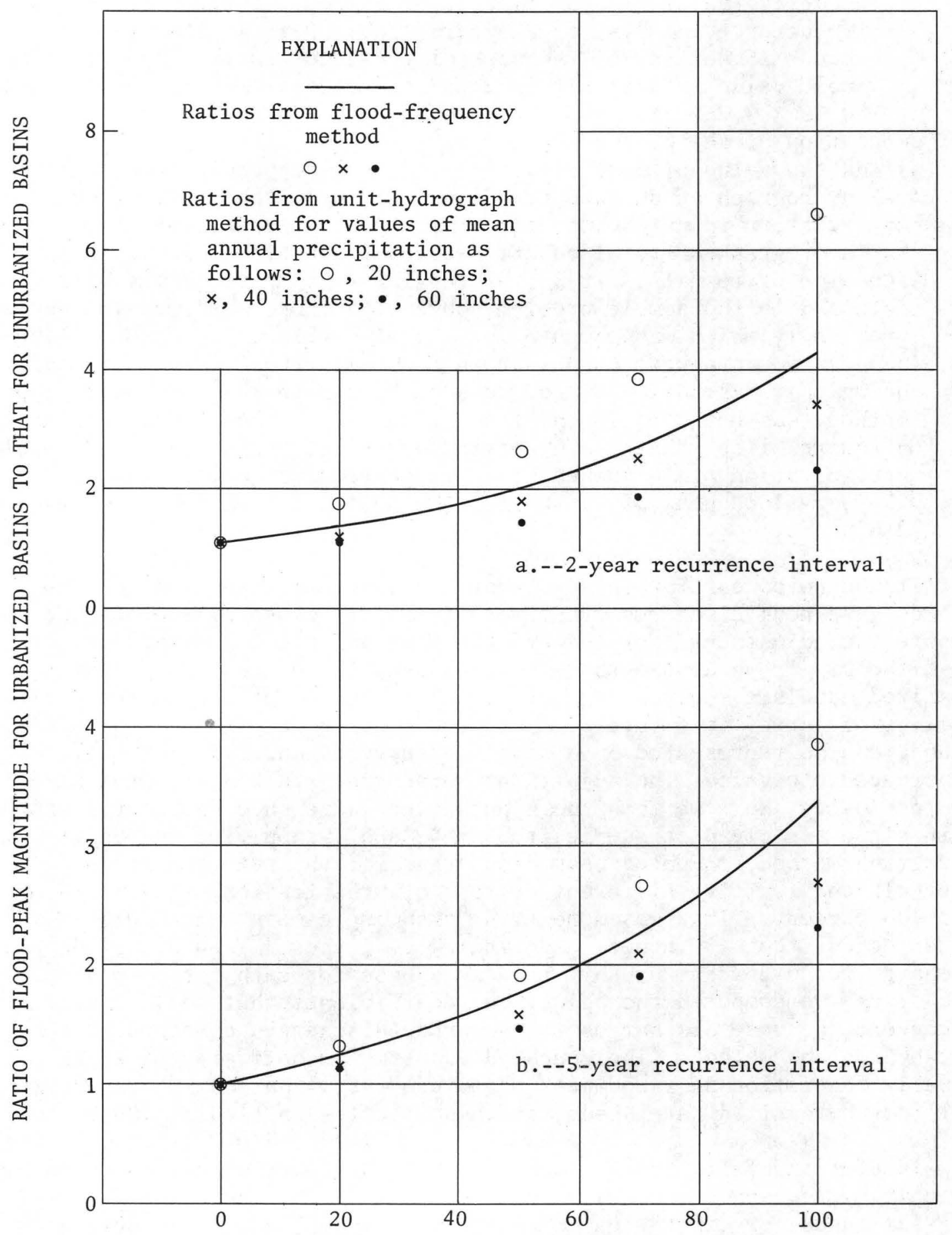

PERCENTAGE OF BASIN URBANIZED

FIGURE 10.--Comparison of ratios of flood-peak magnitude for urbanized basins to that for unurbanized basins, obtained by flood-frequency and unit-hydrograph methods, for 2- and 5-year recurrence intervals. 


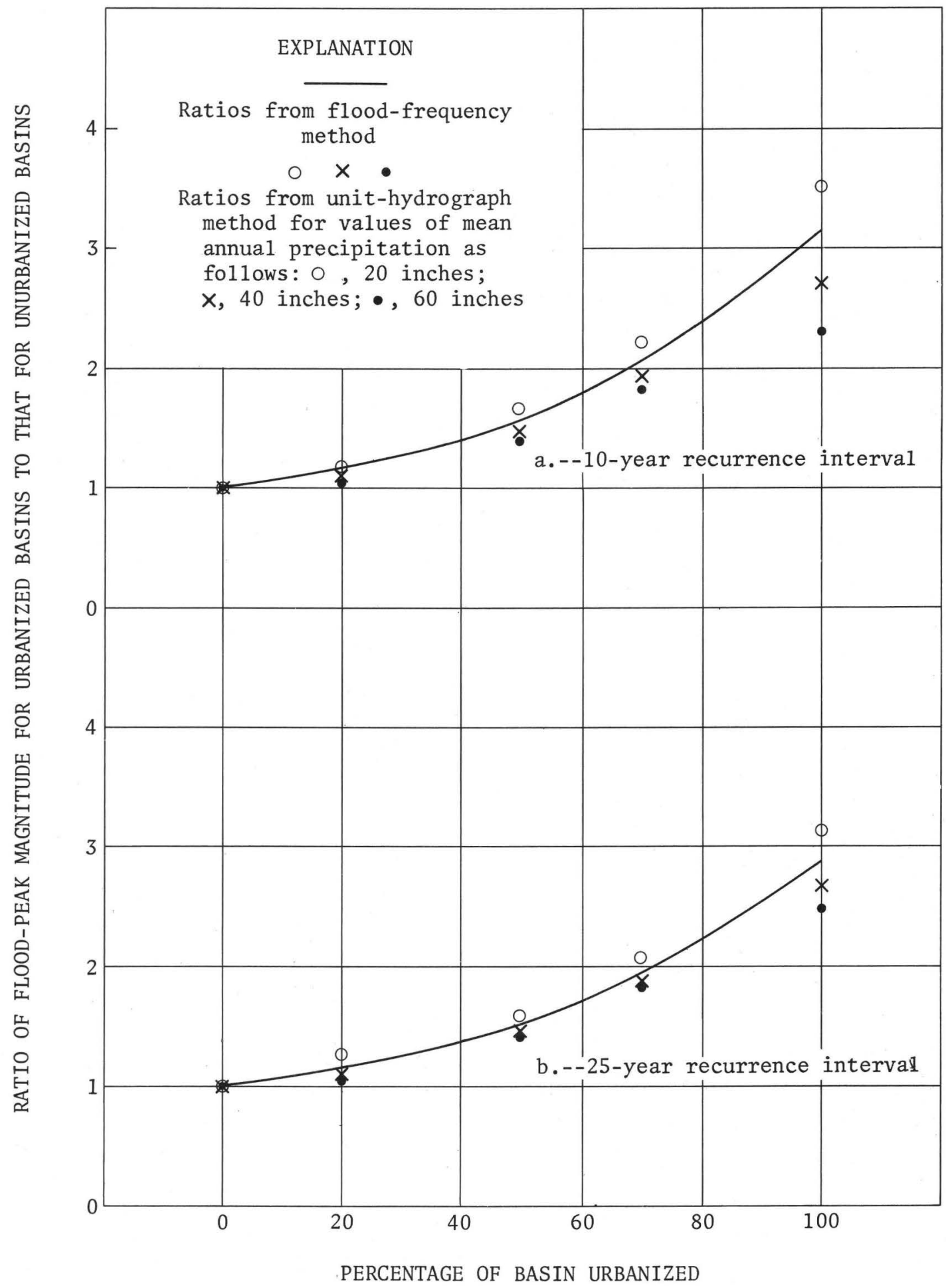

FIGURE 11.--Comparison of ratios of flood-peak magnitude for urbanized basins to that for unurbanized basins, obtained by flood-frequency and unit-hydrograph methods, for 10- and 25-year recurrence intervals. 


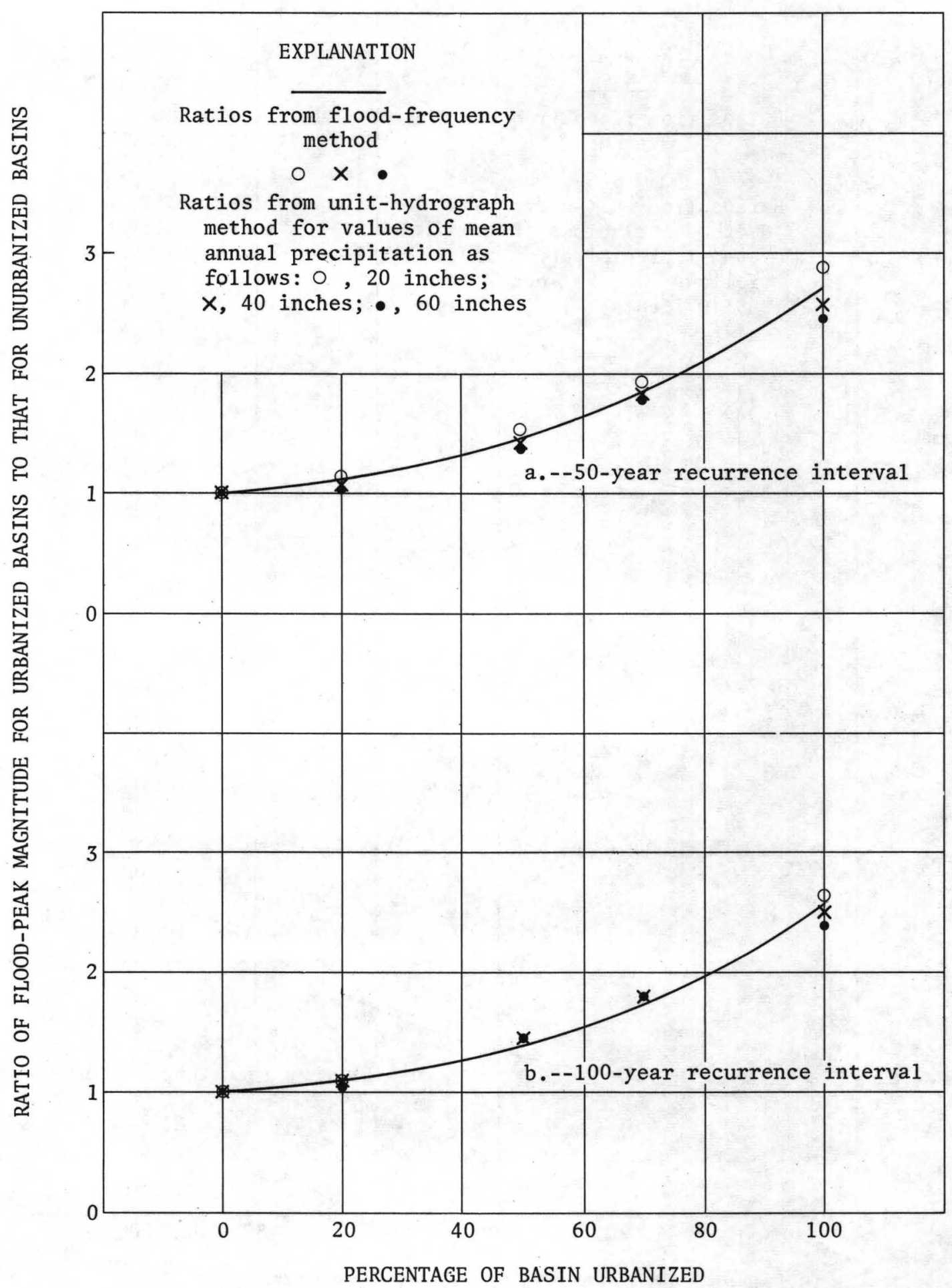

FIGURE 12.--Comparison of ratios of flood-peak magnitude for urbanized basins to that for unurbanized basins, obtained by flood-frequency and unit-hydrograph methods, for 50- and 100-year recurrence intervals. 


\section{Appraisal of Method}

The unit-hydrograph method, although more complex in application than the flood-frequency method or Rational Method, has the advantage of providing a complete storm hydrograph rather than just the peak discharge. Thus, in dealing with a complex watershed, the storm hydrograph for each simple subwatershed can be computed independently by the unit-hydrograph method, for subsequent routing down the main channe1. No such direct procedure for combining flood peaks from subwatersheds is possible with the other two methods. The complete storm hydrograph is also needed in studies involving water quality.

The unit-hydrograph method, like the Rational Method, assumes that the frequencies of peak discharge and peak precipitation rate are identical. This assumption is believed to be generally valid in the San Francisco Bay region, and support for that belief is found in the fairly close agreement of peak discharges computed by flood-frequency analysis and by the unit-hydrograph method. The chief weakness of the unit-hydrograph method, particularly in its application to ungaged watersheds, is in the determination of the all-important rate of infiltration loss. It was hoped that a relation could be found between the infiltration rate and soil type, as indicated by a generalized soils map of the region. Such was not the case, however. The relating of infiltration loss to storm precipitation or to mean annual precipitation, which was resorted to in this study, has some validity in that mean annual precipitation is related in a general way to many of the factors that influence infiltration rates. For example, heavy precipitation is associated with high altitude, which in turn is associated with steep slopes and shallow soil mantle.

Although there are uncertainties connected with the values of parameters used in the unit-hydrograph method, the reationale on which the method is based is more satisfactory, to the author at least, than that underlying either the flood-frequency method or the Rational Method. That, coupled with the fact that the unit-hydrograph method gave satisfactory results for the larger basins with long-term discharge records in the region, leads him to believe that the unit-hydrograph method will give better results for the small basins than either of the other two methods. It will be recalled that the discharge records for the small basins in the region are generally of inadequate length for satisfactory evaluation of any method of storm-discharge analysis.

The adjustments for the effect of urbanization used with the unithydrograph method are subject to the same uncertainties as those used with the flood-frequency method, because of the lack of basic data for defining the effects of urbanization on runoff parameters. 


\section{RUNOFF SIMULATION USING HYDROLOGIC BASIN MODELS}

The use of hydrologic basin modeling for simulating storm runoff is certainly the most rational approach to the study of the flood hydrology of sma11 watersheds. Application of the method has been made feasible by the widespread use of electronic computers. It is not possible to do justice to the method, even in a summary way, within the space limitations of this report, and the reader is referred, therefore, to the detailed discussions in the references cited below.

Many hydrologic basin models for use in runoff simulation are under investigation, but the only ones now (1971) operational for studies of storm runoff from sma11 watersheds are the USGS Watershed Mode1 (Dawdy and others, 1970) and various versions of the Stanford Watershed Mode 1 (Crawford and Linsley, 1966). Both the USGS and Stanford models use precipitation and pan evaporation as hydrometeorological inputs; both maintain a water budget that is balanced at short intervals (usually every 15 minutes during storm periods); both require only a short period of runoff record for model calibration. Neither model requires the assumption of identical frequencies for peak discharge and peak precipitation rates, because both require the use of historic sequences of storm precipitation over a period of years long enough to permit statistical frequency analysis of the derived discharge data. The precipitation data used must be those obtained from a recording gage, and because such data are comparatively scarce, storm data must often be transposed from a distant climatological station to the study basin. This has at times been a deterrent to the hydrologic modeling of small basins in regions of storm variability. In recognition of that difficulty, this section of the report deals primarily with a technique for transposing concurrent storm precipitation from one site to another.

\section{Transposition of Storm-Precipitation Data}

The assumption underlying the transposition of storm-precipitation data is that if a region is hydrologically homogeneous--as is the San Francisco Bay region--the time distribution of storm precipitation over a long period of years is similar for any two sites in the region, even though concurrent storms at the two sites may be dissimilar to varying degrees. On the basis of that assumption--a not unreasonable one--the storm precipitation recorded at the outlying site is applied to the basin model, and the required discharges are computed. For small study basins it is necessary to work with short time increments of storm precipitation, which are commonly in the range of from 5 to 15 minutes. 
If the total precipitation for months or years is consistently greater at site $A$ than it is at site B, individual storm totals will usually also be greater at site A. The converse is true if $\mathrm{A}$ is the drier site. Therefore it is necessary to adjust the magnitude of precipitation increments observed at site $A$ when they are transposed for use at site $B$. We know that when we consider precipitation increments of 1 day or longer, we can usually make the adjustment satisfactorily by assuming that the ratio of precipitation increments at the two sites equals the ratio of mean annual precipitation at those sites. That is the standard U.S. Weather Bureau method of filling in gaps in a "broken" record of precipitation, although the average of the ratios for three stations is genera11y used by the Weather Bureau. (It is assumed here that the values of mean annual precipitation for all sites are known or are available from an isohyetal map.) Also, if the mean annual precipitation at sites A and B differ little from each other, the assumption of equal ratios may be satisfactory for use with increments of precipitation for durations shorter than 1 day.

However, if site $A$ is much wetter (or drier) than site B, the assumption of equal ratios is seldom true for increments of precipitation of less than 1-day duration, and is rarely true for peak intensities whose duration is 1 hour or less. It is obvious then that we cannot use the same adjustment factor for all increments of precipitation throughout a storm. For example, assume that we have a 24-hour storm at site A that we wish to transpose to site B, and that the adjustment factor for total storm precipitation, on the basis of ratios of mean annual precipitation, is 1.50 . If we find that the peak hour of precipitation requires an adjustment factor of 1.25 , it means that in order for total storm precipitation at site $B$ to equal 1.50 times the storm precipitation at site $A$, we must apply varying factors to the remaining 1 -hour storm increments, including a factor in excess of 1.50 .

So much for generalities; we now turn our attention to the San Francisco Bay region. It is well known that not only does storm precipitation in the region increase with mean annual precipitation, but storm duration also increases to a degree with total precipitation. Therefore, the relation of storm precipitation to mean annual precipitation is not a direct one, although for durations of 3 days or more, the departure from a direct ratio could not be detected. In other words,

$$
P_{D T}=a+b P_{M A},
$$

where $P_{D T}=$ storm precipitation of duration $D$ hours or days and recurrence interval $T$ years,

$P_{M A}=$ mean annual precipitation, and $a$ and $b=$ constants.

For durations of three days or more, $a=0$. From these equations Rantz (1971) produced a table of precipitation depth-duration-frequency values, a part of which has been reproduced in this report as table 4 . 
The graphs shown as figures 13-18 were derived from the precipitation frequency data. Those graphs relate precipitation ratios for six precipitation durations--1, 2, 3, 6, 12, and 24 hours--to ratios of mean annual precipitation. For each value of mean annual precipitation used as a base for computing the ratios, we obtain an individual relation of ratios; recurrence interval has little effect on the individual relations. In each of the six figures are shown relations for three base values of mean annual precipitation--20, 40, and 60 inches. An example of the computations, that for deriving the dashed curve (40 inches) in figure 13, is shown in table 18 and should be self-explanatory. The upper half of table 18 has been copied from table 4. Points defining the dashed curve for 40 inches in figure 13 are obtained from table 18 by using the ratios shown in the last row as abscissa values, and those in the next-to-last row as ordinate values.

TABLE 18.--Derivation of curve for mean annual precipitation of 40 inches in figure 13

\begin{tabular}{|c|c|c|c|c|c|c|c|c|c|c|}
\hline \multirow{2}{*}{ Duration } & & \multicolumn{9}{|c|}{$\begin{array}{l}\text { Storm precipitation, in inches, corresponding to indicated } \\
\text { values of mean annual precipitation }\left(\mathrm{P}_{\mathrm{MA}}\right) \text {, in inches }\end{array}$} \\
\hline & $\begin{array}{r}\text { interval } \\
\text { (years) }\end{array}$ & 10 & 16 & 20 & 30 & 40 & 50 & 60 & 70 & 80 \\
\hline 1 hour & $\begin{array}{r}2 \\
5 \\
10 \\
25 \\
50 \\
100\end{array}$ & $\begin{array}{r}0.28 \\
.43 \\
.52 \\
.60 \\
.66 \\
.72\end{array}$ & $\begin{array}{r}0.41 \\
.55 \\
.66 \\
.78 \\
.84 \\
.91\end{array}$ & $\begin{array}{r}0.48 \\
.61 \\
.73 \\
.86 \\
.93 \\
1.00\end{array}$ & $\begin{array}{r}0.56 \\
.72 \\
.84 \\
.99 \\
1.07 \\
1.15\end{array}$ & $\begin{array}{r}0.64 \\
.82 \\
.96 \\
1.12 \\
1.21 \\
1.30\end{array}$ & $\begin{array}{r}0.72 \\
.92 \\
1.08 \\
1.25 \\
1.35 \\
1.45\end{array}$ & $\begin{array}{l}0.80 \\
1.03 \\
1.19 \\
1.38 \\
1.49 \\
1.60\end{array}$ & $\begin{array}{l}0.88 \\
1.14 \\
1.30 \\
1.51 \\
1.63 \\
1.75\end{array}$ & $\begin{array}{l}0.96 \\
1.24 \\
1.42 \\
1.64 \\
1.77 \\
1.90\end{array}$ \\
\hline
\end{tabular}

On each horizontal line of table above, divide each value of precipitation by the value in the column for 40 inches of mean annual precipitation. Ratios obtained are as follows :

\begin{tabular}{rrrrr|r|rrrrr}
2 & 0.43 & 0.64 & 0.75 & 0.87 & 1.00 & 1.12 & 1.25 & 1.37 & 1.50 \\
5 & .52 & .67 & .74 & .88 & 1.00 & 1.12 & 1.26 & 1.39 & 1.51 \\
10 & .54 & .69 & .76 & .88 & 1.00 & 1.12 & 1.24 & 1.35 & 1.48 \\
25 & .54 & .70 & .77 & .88 & 1.00 & 1.12 & 1.23 & 1.35 & 1.46 \\
50 & .54 & .69 & .77 & .88 & 1.00 & 1.12 & 1.23 & 1.35 & 1.46 \\
100 & .55 & .70 & .77 & .88 & 1.00 & 1.12 & 1.23 & 1.35 & 1.46 \\
\hline $\begin{array}{c}\text { Average storm } \\
\text { precipitation ratio }\end{array}$ & 0.54 & 0.68 & 0.76 & 0.88 & 1.00 & 1.12 & 1.24 & 1.35 & 1.46 \\
\hline $\begin{array}{c}\text { Mean annual } \\
\text { precipitation ratio }\end{array}$ & 0.25 & 0.40 & 0.50 & 0.75 & 1.00 & 1.25 & 1.50 & 1.75 & 2.00 \\
\hline
\end{tabular}




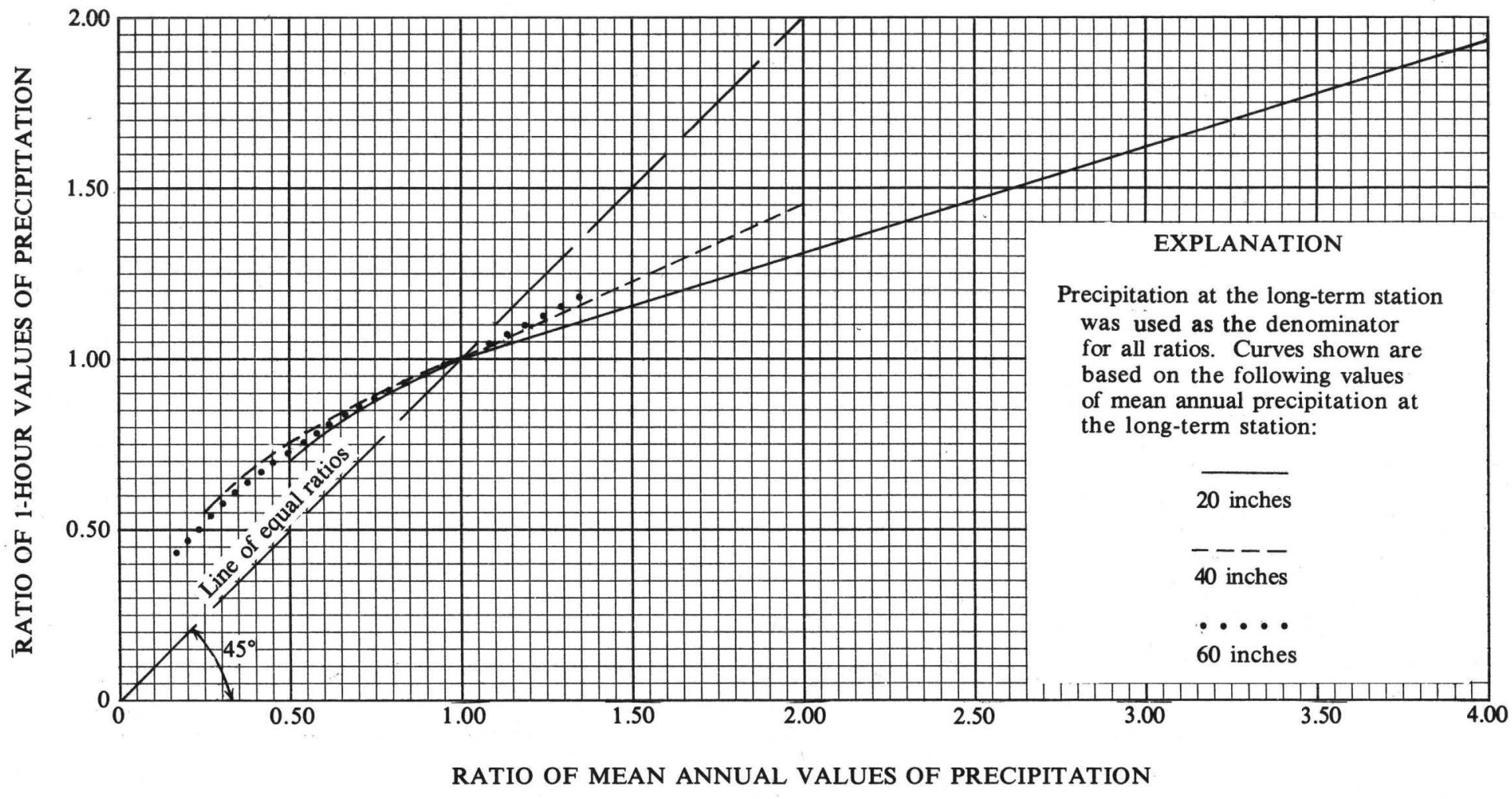

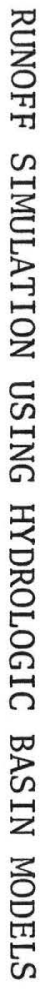

FIGURE 13.--Curves relating 1-hour precipitation ratios to mean annual precipitation ratios. 


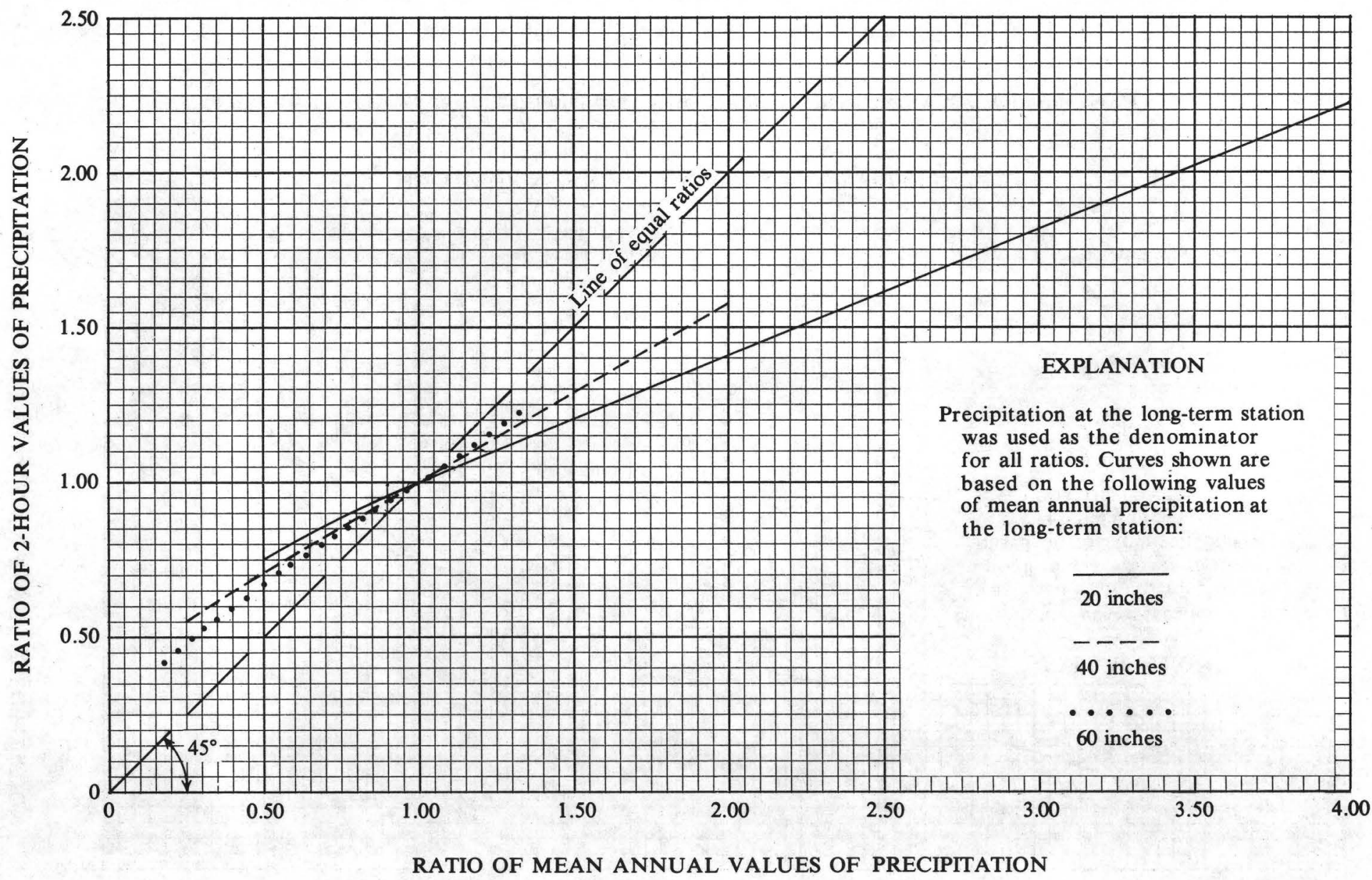

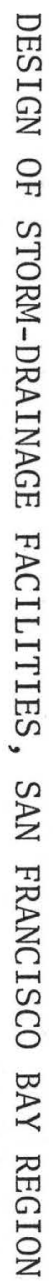

FIGURE 14.--Curves relating 2-hour precipitation ratios to mean annual precipitation ratios. 


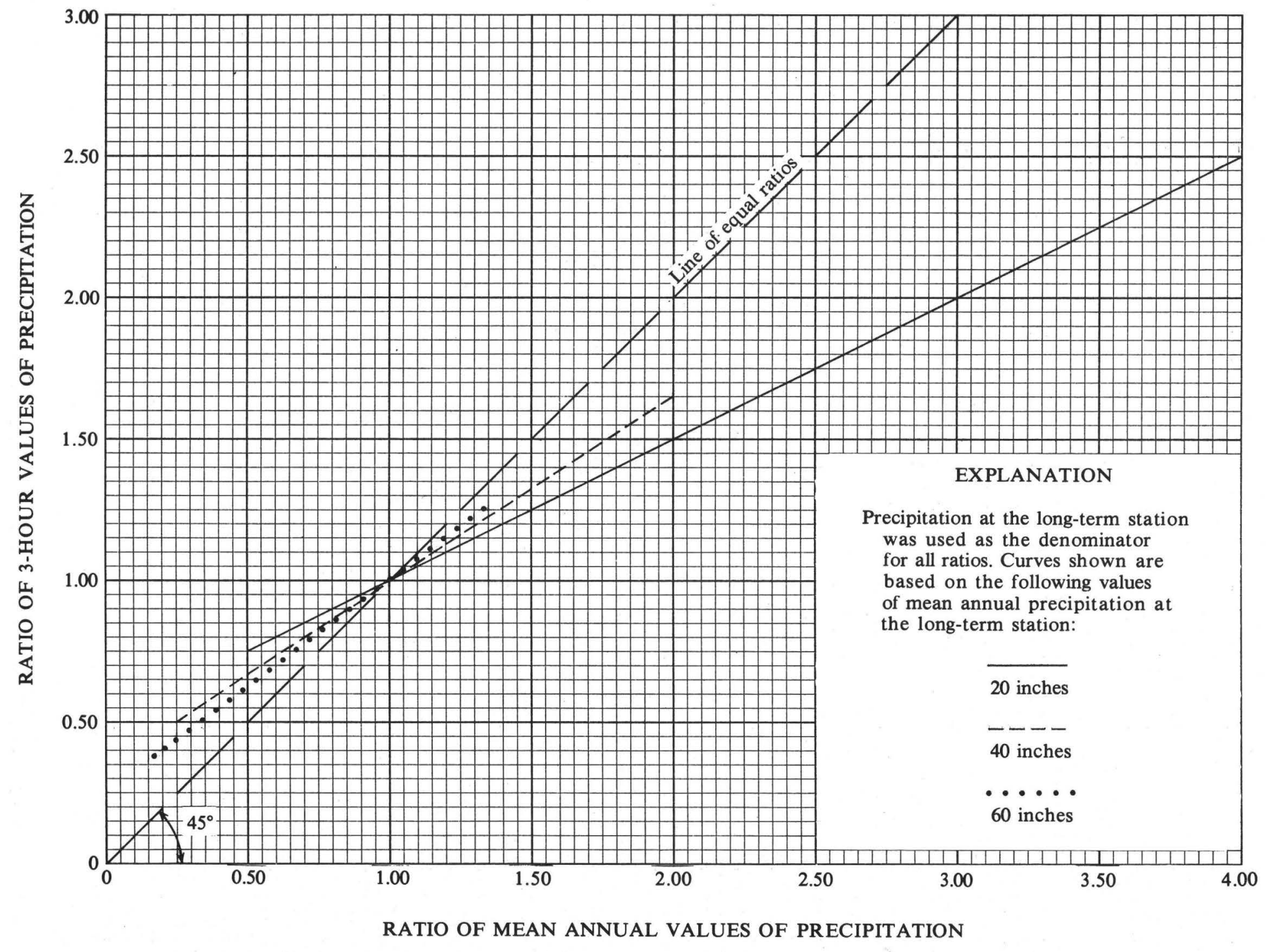

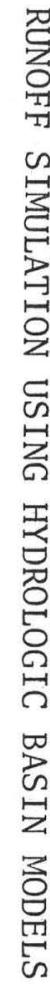

FIGURE 15.--Curves relating 3-hour precipitation ratios to mean annual precipitation ratios. 


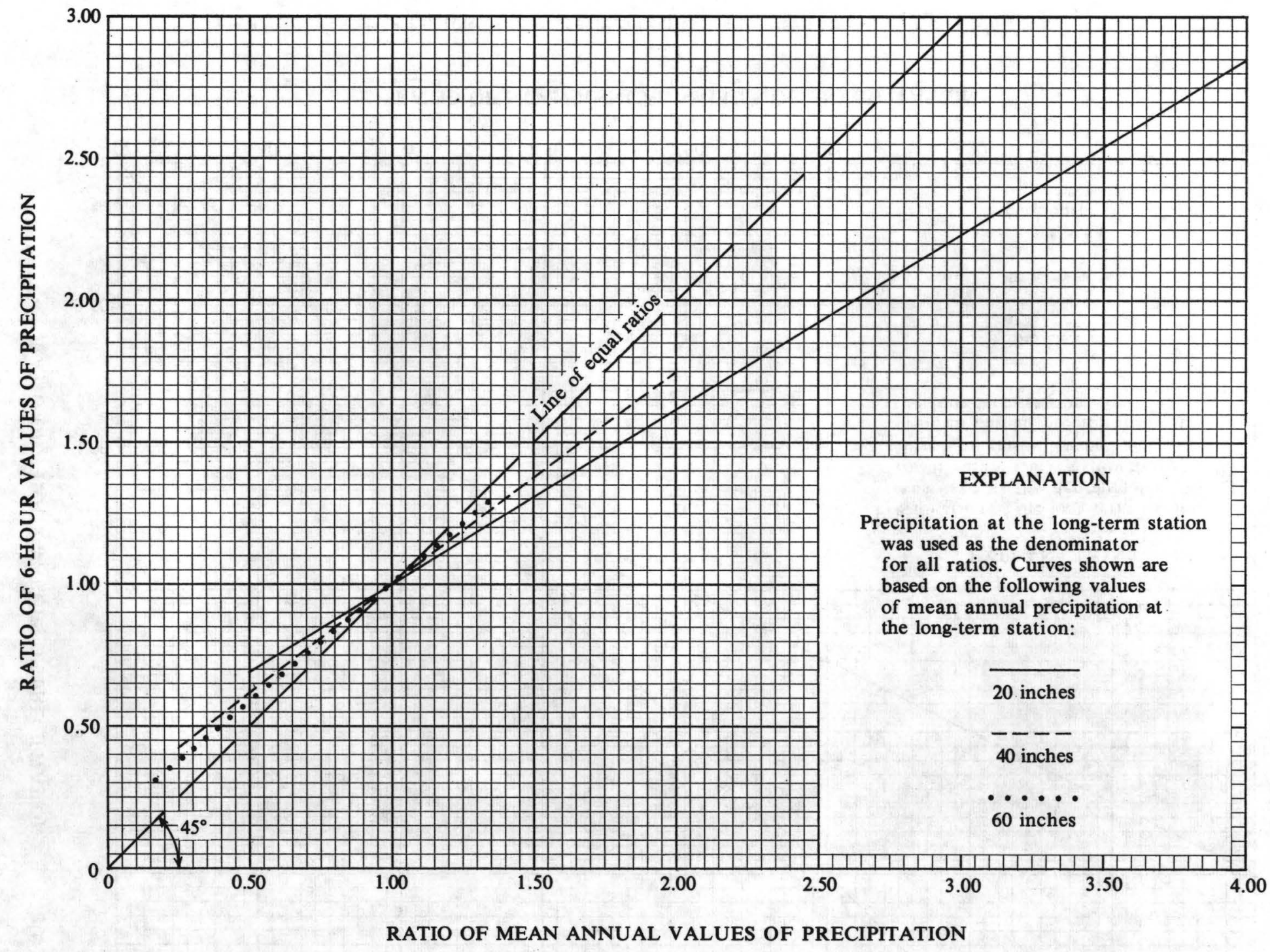

FIGURE 16.--Curves relating 6-hour precipitation ratios to mean annual precipitation ratios. 


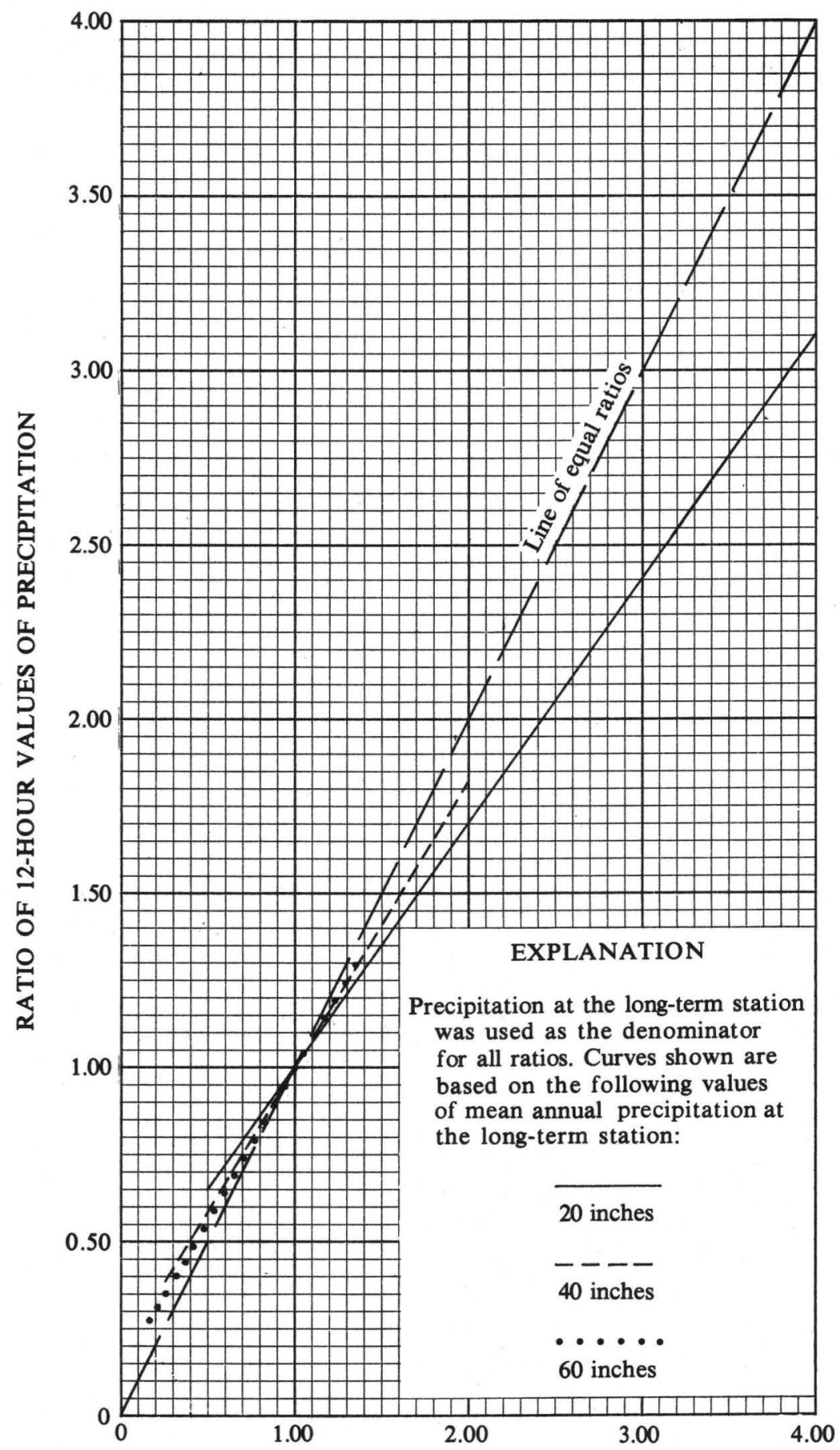

RATIO OF MEAN ANNUAL VALUES OF PRECIPITATION

FIGURE 17.--Curves relating 12-hour precipitation ratios to mean annual precipitation ratios. 


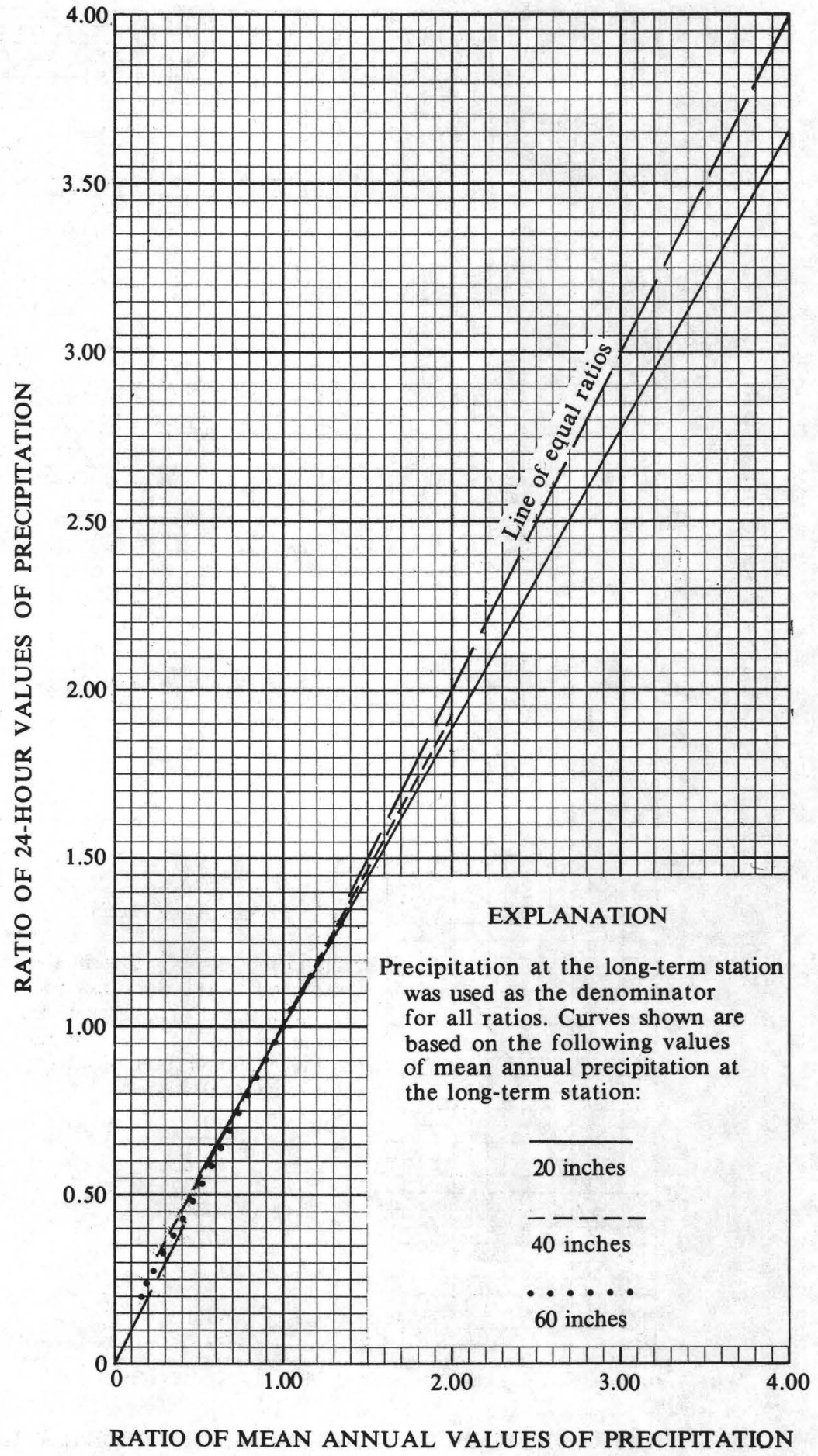

FIGURE 18.--Curves relating 24-hour precipitation ratios to mean annual precipitation ratios. 
The ratios of 24-hour precipitation values (fig. 18) differ very little from the ratios of mean annual precipitation. From a statement in the preceding paragraph we know that storm ratios for durations of 3 days or more are identical with ratios of mean annual precipitation. The relations in figures 13-18, although based on ranked data, can be used to transpose increments of storm precipitation from sjte A to site B in the San Francisco Bay region. The usual objections to relating ranked data do not apply here because all sites in the region have almost identical precipitation regimes and distributions, and furthermore the transposed data will not be used to simulate the runoff event for a given date. Instead, many years of transposed data will be used to determine the distribution of flood peaks. Furthermore, had figures 13-18 been derived from the ratios of concurrent precipitation data rather than from ranked data, the same curves undoubtedly would have resulted because of the hydrologic homogeneity of the region. There would have been a wide scatter of plotted points, however, instead of the close curve fit given by the use of ranked data.

\section{Application of Storm-Increment Ratios}

To illustrate the use of figures 13-18, let us assume that we wish to transpose precipitation increments of 15 minutes' duration from an outlying long-term recording precipitation station to our study basin. Assume further that mean annual precipitation for the station is 40 inches and that for the study basin is 60 inches. The ratio of mean annual precipitation, using the precipitation station record as a base, is 1.50 . From figure 13, using the curve for a mean annual precipitation of 40 inches, the adjustment factor for the peak hour of precipitation at the outlying precipitation station is 1.23 . The factor 1.23 would be applied to each of the four 15-minute intervals during the peak hour at the station. Figure 14 shows the adjustment factor for a 2-hour duration to be 1.28. We would select the period of maximum 2-hour precipitation at the precipitation station--a period that included the previously used 1-hour precipitation--and multiply precipitation for the four unused 15-minute periods by a factor such that the adjusted 2-hour precipitation for the basin equaled 1.28 times the 2 -hour precipitation recorded at the station. Using figures 15-18, a similar procedure would be followed for the remaining increments of precipitation during the peak 24 hours of rainfall at the precipitation station. Figure 18 indicates that the ratio of mean annual values, 1.50 in this case, can be used for durations of 24 hours or more.

The procedure just explained is somewhat involved, but its use should bring about procedural simplifications that will still reduce, to acceptable limits, the bias that would result from using mean annual ratios for all incremental precipitation values. 
It was mentioned on page 57 that because we use ratios less than the mean annual ratio at the height of the storm, when transposing precipitation data from a less humid to a more humid site, it will be necessary to use ratios greater than the mean annual ratio during the slack part of the storm, if our precipitation ratios for periods of one day or more are to equal the mean annual ratio. (The reverse is true when transposing data from a more humid to a less humid site.) Those statements require some elaboration. Because of the tendency of the more humid sites to have storms of greater duration than the less humid sites, there are actually more time increments of precipitation at the wetter sites. However, we do not attempt a time adjustment for the difference in storm duration at the two sites. Instead, we compensate by applying to the period of relatively light precipitation the adjustment needed to preserve the mean annual ratio of storm totals at the two sites. By making this adjustment during periods of 1 ight rainfall we eliminate bias in the computation of the heavier rates of runoff, and at the same time we do not seriously affect the accuracy of our total hydrograph.

\section{Appraisa1 of Method}

The method described for transposing storm precipitation from the site of an outlying recording precipitation gage to the watershed under study is practicable for use in the San Francisco Bay region. That is so because of the precipitation regime of the region wherein (1) the bulk of the annual precipitation occurs in several general storms each year;

(2) each storm usually covers the entire region; (3) severe convectional storms are virtually unknown in the region. There are two alternatives to using the proposed method of storm transposition. The first alternative would be to transpose incremental precipitation from the outlying precipitation station to the study basin, using the ratio of mean annual precipitation throughout the procedure. We have learned from experience that that procedure introduces a bias in the computed peak discharges if the magnitude of mean annual precipitation at the two sites differs significantly. The other alternative is to statistically generate a simulated sequence of precipitation events covering a long period of years. That alternative, at the present state of the art at least, does not give results as satisfactory as those that can be obtained by the proposed method of precipitation transposition. Therefore, rainfall simulation at present is to be considered only when no direct method of storm transposition is practicable. 
As for hydrologic basin modeling in general, it is the most reliable method of obtaining long-term storm-runoff data for watersheds with short-term discharge records. The basin water budget maintained in the modeling procedure enables the hydrologist to estimate abstractions from storm precipitation far better than can be done conventionally, using such empiricisms as an antecedent precipitation index. However, at the present state of the art, the advantage of hydrologic basin modeling for ungaged basins has not been clearly demonstrated because of the difficulty of estimating the numerical values of the many interacting parameters used in the models. Nevertheless, the complex distributive hydrologic basin models that are being developed by the Geological Survey and others are what is needed for the scientific design of storm drainage; only those models are capable of considering the individual characteristics of basins, both developed and undeveloped.

\section{SUGGESTED PRACTICES TO REDUCE PEAK DISCHARGES IN URBAN AREAS}

It seems appropriate to conclude this paper with a brief discussion of suggested practices to reduce peak discharges in urban areas. We have seen that urbanization may cause the flood peaks that result from a given storm to increase by a factor ranging from two to nearly seven (figs. 10-12). It is usually poor economics, however, to design drainage facilities on the scale needed to provide immediate rapid removal of those large concentrations of water, if temporary storage or ponding of the storm runoff can be incorporated in the urban design to achieve significant reduction in the peak rate of runoff. The measures that may be taken will be governed by local conditions.

The ponding of rainfall on source areas of runoff, such as roofs, parking lots, and elevated plazas, is an obvious means of reducing peak discharge. Mention was made early in this paper of the flat roofs used in many residential developments in the Palo Alto area. Whether or not that design was adopted for its effect on street drainage is immaterial; the fact remains that the roofs in those developments are effective in providing storage--their downspouts may discharge rainwater for as long as 24 hours after the cessation of a prolonged storm. Elevated plazas and parking lots can be designed with drains located at elevations to accommodate predetermined depths of storage on the paved surfaces. The occasional inconvenience to pedestrians that results can be minimized by careful selection of walkway and drain locations. The measures described above are not effective in areas of heaviest mean annual precipitation in the San Francisco Bay region because of the nature of the precipitation regime. Heavy runoff invariably results from prolonged general storms, and in the most humid areas the permissible storage surcharge on the flat surface may be reached before peak intensities of rainfall occur. In that case the drains would have to carry runoff at virtually the peak rainfall rate and no significant reduction in peak dishcarge would be achieved. 
In areas where subsurface conditions are favorable, the use of dry wells to conduct some of the above-described drainage underground will not only reduce drainage problems, but will also recharge the underlying ground-water body. Water-quality considerations will usually rule out the use of dry wells for the drainage of parking lots. The use of dry wells would be unthinkable, too, where urban development had taken place on unstable slopes. In terrain of that kind the slide hazard increases with the quantity of water that seeps below land surface. It is obvious that under those conditions storm water should be removed as rapidly as possible to reduce the time available for surface-water seepage.

Storm-sewer inlets on paved streets should be designed, as they commonly are in modern practice, to create temporary ponding between street curbs during extreme storm events.

From a standpoint of esthetics, stream channels should be maintained in, or restored to, their natural state, and the flood plain zoned for uses that are compatible with occasional flooding. For example, in residential areas a preferred use is for parkland, and in commercialindustrial areas preferred use is for parking lots or structures easily flood-proofed. Where urban development has already encroached on the flood plain, there is no recourse but to obtain maximum efficiency of the channel by improving its alinement and decreasing its friction factor--by paving, if necessary. If the stream is small it may be possible to obtain relief from flooding by constructing a detention basin or impoundment on up-stream undeveloped area. The greatest reduction in peak flow rate will be achieved by constructing the detention basin or impoundment as close to the threatened area as is feasible.

Recreational fields and other open areas often provide excellent ponding opportunities. Many municipalities--Madison, Wis., for example-require that "greenways" be established in every new residential development. Greenways are defined as open areas of land within an urban area for the prime purpose of storing and conveying storm-water runoff. Greenways usually serve multiple purposes. In addition to acting as ungated detention reservoirs, they serve as playgrounds, parks, and esthetic buffers between dissimilar land uses.

It goes without saying that if storage, of the types described in the preceding paragraphs, is to be provided, a procedure for routing design flows through the storage elements of the drainage system must be incorporated in the hydrologic design. Further discussion on design practices to reduce peak discharges in urban areas is found in articles by Rice (1971) and Schneider (1971), and in a previously cited manual by the American Society of Civil Engineers (1969, p. 61-62). 


\section{REFERENCES CITED}

American Society of Civil Engineers, 1969, Design and construction of sanitary and storm sewers: Manuals and Repts. on Eng. Practices No. $37,332 \mathrm{p}$.

Anderson, D. G., 1970, Effects of urban development on floods in northern Virginia: U.S. Geol. Survey Water-Supply Paper 2001-C, 22 p.

Ardis, C. V., Dueker, K. H., and Lenz, A. T., 1969, Storm drainage practices of thirty-two cities: Am. Soc. Civil Engineers, Hydraulics Div. Jour., v. 95, no. HY1, p. 383-408.

Crawford, N. H., and Linsley, R. K., 1966, Digital simulation in hydrology, Stanford watershed model IV: Stanford Univ. Dept. Civil Eng. Tech. Rept. 39, $210 \mathrm{p}$.

Dawdy, D. R., Lichty, R. W., and Bergmann, J. M., 1970, A rainfa11-runoff simulation model for estimation of flood peaks for small drainage basins--A progress report: U.S. Geol. Survey open-file rept., 102 p.

James, L. D., 1965, Using a computer to estimate the effects of urban development on flood peaks: Water Resources Research, v. 1, no. 2, p. 223-234.

Linsley, R. K., Kohler, M. A., and Paulhus, J. L. H., 1949, Applied hydrology: New York, McGraw-Hill Book Co., 689 p.

Rantz, S. E., 1971, Mean annual precipitation and precipitation depthduration-frequency data for the San Francisco Bay region, California: U.S. Geol. Survey open-file rept., 23 p.

Rice, Leonard, 1971, Reduction of urban runoff peak flows by ponding: Phoenix, Ariz., Am. Soc. Civil Engineers Nat1. Water Resources Eng. Mtg. Preprint 1298.

Santa Clara County, 1965, Master storm drainage plan--Summary report and standard design flows: San Jose, Santa Clara County Dept. Pub. Works, 34 p., 2 apps.

Schneider, W. J., 1971, Hydrologic data for storm drainage design: Phoenix, Ariz., Am. Soc. Civil Engineers Nat1. Water Resources Eng. Mtg. Preprint 1328 .

U.S. Soil Conservation Service, 1957, Hydrology guide for use in watershed planning, in National Engineering Handbook, sec. 4, supp. A.

U.S. Water Resources Counci1, 1967, A uniform technique for determining flood flow frequencies: Washington, D.C., Water Resources Council, Bu11. 15, 15 p.

Wright-McLaughlin Engineers, 1969, Urban storm drainage criteria manual: Denver Regional Council of Governments, Denver, Colo. 